UNIVERSIDADE DE SÃO PAULO

FACULDADE DE FILOSOFIA, LETRAS E CIÊNCIAS HUMANAS

DEPARTAMENTO DE LETRAS CLÁSSICAS E VERNÁCULAS

PROGRAMA DE PÓS-GRADUAÇÃO EM LITERATURA BRASILEIRA

ENTRE A PROSOPOPEIA E A VIAGEM: POÉTICA E NARRATIVA POR LETRAS COLONIAIS

Lucinéa Rinaldi

Orientador: Eduardo de Almeida Navarro

São Paulo

2016 


\section{UNIVERSIDADE DE SÃO PAULO \\ LUCINÉA RINALDI}

\section{ENTRE A PROSOPOPEIA E A VIAGEM: POÉTICA E NARRATIVA POR LETRAS COLONIAIS}

Tese apresentada ao Programa de Pós-Graduação em Letras, para a Área de Literatura Brasileira, do Departamento de Letras

Clássicas e Vernáculas, da Faculdade de Filosofia, Letras e

Ciências Humanas, da Universidade de São Paulo, como requisito parcial para a obtenção do Título de Doutor em Letras.

Orientador: Eduardo de Almeida Navarro

SÃO PAULO

2016 
UNIVERSIDADE DE SÃO PAULO

FACULDADE DE FILOSOFIA, LETRAS E CIÊNCIAS HUMANAS

DEPARTAMENTO DE LETRAS CLÁSSICAS E VERNÁCULAS

PROGRAMA DE PÓS-GRADUAÇÃO EM LITERATURA BRASILEIRA

PROSOPOPEYA AND TRAVELS: POETICS

AND NARRATIVE THROUGH COLONIAL WRITINGS

Lucinéa Rinaldi

lucinearinaldi@uol.com.br

5511989234000

Orientador: Eduardo de Almeida Navarro

São Paulo

2016 
Autorizo a reprodução e divulgação total ou parcial deste trabalho, por qualquer meio convencional ou eletrônico, para fins de estudo e pesquisa, desde que citada a fonte.

Catalogação na Publicação

Serviço de Biblioteca e Documentação

Faculdade de Filosofia, Letras e Ciências Humanas da Universidade de São Paulo

\section{Rinaldi, Lucinéa}

R578e Entre a Prosopopeia e a Viagem: poética e narrativa por letras coloniais / Lucinéa Rinaldi;

Orientador Eduardo de Almeida Navarro. - São Paulo, 2016.

$144 \mathrm{f}$.

Tese (Doutorado)- Faculdade de Filosofia, Letras e Ciências Humanas da Universidade de São Paulo.

Departamento de Letras Clássicas e Vernáculas. Área de concentração: Literatura Brasileira.

1. Olinda. 2. Pernambuco. 3. Viagem. 4. Educação. 5. Direitos.

I. Navarro, Eduardo de Almeida, orientador.

II. Título. 


\section{BANCA EXAMINADORA}

Professor: Dr. Eduardo de Almeida Navarro (Orientador) FFLCH / USP Professora: Dra. Eneida Beraldi Ribeiro Centro Paula Souza / SP Professora: Dra. Neusa Maria Oliveira Barbosa Bastos UPM Professor: Dr. Cosme Freire Marins Professor: Dr. Dadie Kacou Christian 
RINALDI, Lucinéa. Entre a Prosopopeia e a Viagem: poética e narrativa por letras coloniais. São Paulo: Tese de Doutorado, Departamento de Letras Clássicas e Vernáculas, Universidade de São Paulo, 2016.

Aprovada em: I l

\section{BANCA EXAMINADORA}

Prof. Dr. Instituição:

Julgamento: Assinatura:

Prof. Dr. Instituição:

Julgamento: Assinatura:

Prof. Dr. Instituição:

Julgamento: Assinatura:

Prof. Dr. Instituição:

Julgamento: Assinatura:

Prof. Dr. Instituição:

Julgamento: Assinatura: 


\section{Sigla dos acervos pesquisados}

APEJE - Arquivo Público Estadual de Pernambuco

CMGA - Casa Museu Guilherme de Almeida (SP)

FD - Faculdade de Direito da USP

FE - Faculdade de Educação da USP

FFLCH - Faculdade de Filosofia, Letras e Ciências Humanas da USP

FGF - Fundação Gilberto Freyre

FJN / FUNDAJ / IJN - Fundação Joaquim Nabuco

IEB - Instituto de Estudos Brasileiros da USP

IRI - Instituto de Relações Internacionais da USP 
À memória de meus avós, Alcides e Alcidina.

Para Sophia, com carinho.

Ao Gonçalo M. Tavares, com afeto. 
Em Tuas Mãos, Senhor ${ }^{1}$

1 Frase escrita na lápide de Dom Helder Câmara, Arcebispo de Olinda e Recife. 


\section{AGRADECIMENTOS}

Escrever os agradecimentos pela conclusão de uma pesquisa e produção acadêmica não é uma tarefa fácil, justa, na medida em que corremos o risco de deixar de mencionar alguém importante, partícipe de nossa trajetória, momento em que compartilhamos as condicionantes do estudo e do processo de escrita realizada como um todo.

Nesse sentido, a primeira grande voz a quem agradecemos, com carinho, é o professor Dr. Eduardo de Almeida Navarro, pela oportunidade de nos acolher, como doutoranda, no programa de pós-graduação em literatura brasileira, da Universidade de São Paulo, pela atenção e instrução dirigidas, por meio de conversas, sugestões e ajustes.

Ingressamos no programa em fevereiro de 2012, ano em que foram realizados e alcançados os créditos necessários para se desenvolver o tema em questão, aproveitando-se as leituras e reflexões colhidas na dissertação de mestrado defendida em 2007, para o Departamento de Letras Clássicas de Vernáculas da USP, sob o título Cronistas de Viagem e Viajantes Cronistas: o pêndulo da representação no Brasil Colonial.

Não navegamos, a exemplo dos outros orientandos, pelas letras que o Alto Rio Negro guarda e esconde como tesouro, à procura da melhor tradução ou versão para o nheengatu ${ }^{2}$, uma língua compartilhada por diferentes etnias, nosso último refúgio, na condição de língua geral que nos convida a pensar, como uma espécie de cauim, nosso, nutriente cultural porque registra, o fomento de narrativas circulantes necessárias para o campo literário, como fortuna de muitos povos indígenas, herança para todos os brasileiros.

\footnotetext{
2 Segundo Navarro, o nheengatu era a língua mais falada no norte do país, inclusive por brancos e negros, uma vez que suplantava o português entre o final do século XIX e o início do ciclo da borracha.” VIANNA, Branca. Questões Linguísticas: Vida, morte e vida da língua geral. In: O Contrário da Memória. São Paulo: Revista Piauí 116, maio de 2-16. P. 52 a 58.
} 
Durante o percurso da pesquisa, entre a percepção das lendas e descobertas que o rio guarda e das letras coloniais produzidas, sugeriu-nos, num primeiro instante, investigar $O$ Tesouro Máximo do Rio Amazonas, do Padre João Daniel ${ }^{3}$ e, num segundo plano, o Caramuru, de Santa Rita Durão ${ }^{4}$.

Permanecemo-nos, todavia, na condição de Dulcinéia ${ }^{5}$, encantada pelo sonho e projeto de arquitetar a escrita da tese, a partir da epopeia da viagem, a prosopopeia do cantar e do viajar, como grande questão a ser pensada entre os campos da literatura e a história. Assim embarcamos na épica de Bento Teixeira e na viagem descrita e narrada por Henry Koster ao percebermos Pernambuco a partir de uma composição épica e outra contada como viagem por terras brasileiras,

Num segundo momento, mencionamos aqui nossos agradecimentos aos professores doutores Rosemeire França de Assis Rodrigues Pereira, estudiosa sobre José de Anchieta e a gênese da educação brasileira e Luiz Roberto Alves, crítico literário da poética de Bento Teixeira, da fortuna histórico-literária como confissão e teatralidade, em tempos de Inquisição. Professores convidados para o Exame de Qualificação que muito contribuíram com orientação, comentários, correções e bibliografia sugeridas. Profissionais que promovem a construção de saberes, com um olho voltado para a academia e o outro para a escola.

3 “Ao recordar o tempo vivido na Amazônia (1741-1757), nos dezoito anos de reclusão nos cárceres de Lisboa (1757-1783), o jesuíta português João Daniel foi compondo o louvor da terra que foi forçado a abandonar, o que denominou Tesouro Descoberto no Máximo Rio Amazonas. Dividida em seis partes, abrange três grandes painéis: a Terra, o Homem e, a Cultura. A obra, ornada de mitos e símbolos, lembra a lavra do rapsodo, aquele que canta ou recita estórias populares, adaptando-as a seu modo sem perder a autenticidade". SALLES, Vicente. Apresentação. Rapsódia Amazônica de João Daniel. In: Tesouro Descoberto no Máximo Rio Amazonas, do Padre João Daniel. Belém: Contraponto Editora, 2004.

4 DURÃO, Frei José de Santa Rita. Canto Primeiro. In: Caramuru. TEIXEIRA, Ivan. Multiclássicos Épicos. Prosopopeia. O Uraguai. Caramuru. Vila Rica. A Confederação dos Tamoios. I-Juca-Pirama. São Paulo: Edusp. Imprensa Oficial, 2008;

5 "Entre os muitos episódios que representam o embate entre a ilusão de Dom Quixote com uma realidade quotidiana e oposta à ilusão, este ocupa uma posição especial." AUERBACH, Erich. A Dulcinéia Encantada. In: Mimesis. São Paulo, Editora Perspectiva, 2002. P.299 a 320. 
Num terceiro momento, necessário também se faz agradecer aos professores doutores das seguintes disciplinas cursadas, as quais justificam o processo de escrita da tese, a saber: Íris Kantor, Cartografia, Imaginário Geográfico, Narrativas Textuais na Formação do Brasil XVI a XIX, 2012 ${ }^{6}$, FFLCH / USP; Helena Coharik Chamlian, Professor Universitário: Vida, Perfil e Formação, 2012 ${ }^{7}$, FE / USP; Pedro Meira Monteiro, O Ensaio Latino-Americano, 2012 ${ }^{8}$, IEB / USP; Alfredo Bosi, Entre a Literatura e a História, 2013 ${ }^{9}$, FFLCH / USP; Jean Marc Besse, Escrever a História da Geografia Moderna. Questões Epistemológicas, Problemas Historiográficos, $2014^{10}$,

6 O trabalho final versou sobre a primeira parte do Tratado Descritivo do Brasil, de Gabriel Soares de Souza, na condição de descrição cartográfica imaginária, sob a tutela da soberania, apropriação e mimese do processo, com base na historiografia clássica, narrativas textuais e suportes de informação geográfica, segundo o contexto das grandes narrativas sobre a formação territorial do Brasil.

$7 \mathrm{Na}$ disciplina investigamos a formação e a produção docente, acompanhamos a elaboração de relatos de formação, por meio de escuta e análise de experiências em tríades, para a composição de um texto final, fruto da observação dos componentes temáticos abordados em sala de aula. Escrevemos nosso relato por meio da autobiografia, com foco na construção de vida pessoal, laboral e acadêmica em processo.

8 Momento em que lemos e pensamos sobre ensaios e textos em circulação que precisam compor o repertório de um investigador latino-americano sobre estudos acerca do Brasil. O trabalho de conclusão

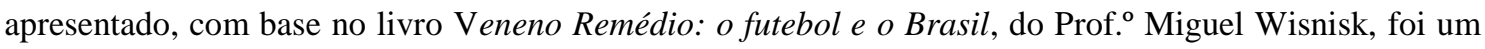
artigo sobre futebol, levando-se em consideração discurso, identidade, singularidade brasileira e cultura latina e norte-americana, sob a temática abordada do "duplo significado das raízes", tomando-se como fonte escritos de Sérgio Buarque de Holanda e Octavio Paz.

9 O trabalho final versou sobre a Interface da Literatura e da História: crônica do Brasil Colônia: recepção, tradução de um mundo de diálogos, discursos e memórias cartográficas imaginárias, por meio de estudos críticos de Otto Maria Carpeaux, revisitando autores e escritos. Observou-se, sob a interface textual e historiográfica, a produção realizada por um inglês, filho de portugueses, que se desloca para viver no Brasil, para cuidar de sua saúde e que decide realizar viagens ao nordeste do Brasil, anotando, arrolando e comunicando informações sobre a terra, a gente e as relações sociais que se estabelecem nos anos finais do Brasil Colônia, Travels in Brazil, de Henry Koster, traduzido por Câmara Cascudo, pensado aqui na condição da experiência descrita e traduzida.

10 O trabalho final apresentado, sob o título De Liverpool a Pernambuco: a terra vista relatada por um viajante inglês, observou as fontes histórico-geográficas fundamentais para a investigação do discurso cartográfico em formação, permeando o lócus descrito e o traduzido, como ponto de partida para se perceber o espaço narrativamente construído, o registro da representação da terra, na condição de objeto geográfico formado com base no discurso do sujeito que, ao percorrer a terra, estabelece a ocupação e a 
FFLCH / UP1; Lúcia Sá, Literaturas da Floresta, 2014 ${ }^{11}$, FFLCH / Manchester University; Carlos Alberto e Moura Ribeiro Zeron e Luce Giard, L'oeuvre multiforme de Michel de Certeau, 2015 12, FFLCH / L'École des Hautes Études en Sciences Sociales; Leon Kossovitch, Estética (Cotejo de obras e textos de artistas modernos), 2015 13, FFLCH / USP; Nina Beatriz Stocco Ranieri, Direito à Educação pelo Estudo de Casos, $2015^{14}$, FD / USP.

apropriação das fronteiras, por meio da descrição de caminhos, ampliando o território como também as condicionantes da existência humana, a qual aos poucos se constituía e se transformava.

11 Foi realizada a releitura de textos de autores brasileiros sob a interface da literatura e da antropologia, abordando-se o estudo da literatura indígena e da etnoliteratura das terras baixas da América do Sul, coletadas entre os povos indígenas ou publicadas por autores brasileiros, a escrita dos cronistas coloniais e românticos, observando-se o impacto dessas narrativas na literatura brasileira, pelos seguintes autores: Gonçalves Dias, Mário de Andrade, Raul Bopp Guimarães Rosa e Darcy Ribeiro sob o Perspectivismo de Eduardo Viveiros de Castro. Realizamos o estudo de Macunaíma e a leitura das narrativas coletadas por Koch-Grünberg.

$12 \mathrm{O}$ trabalho abordou uma proposta de leitura e reflexão para a viagem escrita por Jeán de Léry, dialogando com textos de Michel de Certeau, mediante sugestões, discussões e leituras propostas e vivenciadas entre a história cultural, social e antropológica de conceitos e procedimentos oriundos da filosofia, da linguística e da psicanálise, segundo Luce Giard.

$13 \mathrm{O}$ trabalho versou sobre a condição do Brasil como paisagem, ao partir de uma proposta de se buscar, entre os campos da filosofia e da estética, interlocução e escrita como chave de interpretação poética pela arte do compor e do escrever, entre as gavetas e os guardados de Iberê Camargo e as cartas e as telas de Vincent Van Gogh..

14 A partir de um seminário, elaboramos um trabalho interdisciplinar, com base no repertório arrolado por meio do estudo de documentos jesuíticos sobre a experiência do educar no Brasil, em tempos de Colônia, com o objetivo de se levantar processos e territórios em construção, promotores ou excludentes quanto aos direitos de aprendizagens, necessários à formação de uma cultura de paz, como garantia constitucional a uma cidadania digna, sadia. Analisamos discursos e saberes constantes no pensamento dos seguintes teóricos: Paulo Freire, Anísio Teixeira e Pierre Bourdieu. O estudo de caso partiu da reflexão sobre a ADIn 4439, a Concordata assinada pela Santa Sé e o Estado Brasileiro, a título de Acordo: abordaram-se questões como laicidade, constituição, público alvo, escola, com base na ponderação como medida resolutiva para se entender nossa condição de um Brasil plural, voz presente na composição dessa tese. 
Desejamos também registrar um agradecimento afetuoso à Pousada dos Quatro Cantos $^{15}$, em Olinda, por ter disponibilizado material para a pesquisa, como livros de receita, catálogos e revistas, lugar de muitas memórias e lembranças e, sobretudo, de muita aprendizagem.

Ainda, não podemos deixar de retribuir nossa gratidão a todos os colegas pesquisadores que cruzaram nossos caminhos, ao incentivar-nos a promover o presente trabalho: pelas leituras, estudos, debates e escuta das muitas questões e aflições levantadas, sobretudo pelas palavras de conforto e compreensão.

Tivemos a sorte de encontrar, pelas escolas por onde passamos, na condição de aprendizes permanentes do ofício do ensinar, o que de fato resume a função do professor, um sem número de profissionais e alunos que nos ajudaram a sermos quem somos hoje. Ensinar aprendendo significa fazer a autobiografia das nossas vidas. Numa delas tivemos a felicidade de conhecer o trabalho de um diretor que, na sua grandeza, bondade e sabedoria, autoridade sem ser autoritário, orientou-nos a chamar, uns aos outros, de professor. Dedicamos, assim, um agradecimento especial ao Professor Carlos Alberto de Oliveira, diretor da EMEF Embaixador Raul Fernandes, na Vila Brasilândia, por sua história de vida, como pai, amigo e mestre.

Desejamos resgatar um agradecimento especial a dois leitores que muito contribuíram com comentários, motivação e carinho para a continuidade da pesquisa pelo campo das poéticas e narrativas coloniais, caminho traçado entre a dissertação defendida e a tese em processo, bem como pelo diálogo com nossas fontes lusobrasileiras, dois professores poetas, mestres no ofício do ensinar: "Tia Fátima”, pela poesia de cada dia, professora das primeiras letras na Escolinha Pedacinho de Gente, uma casinha colorida na Casa Verde, repleta das vozes e da práxis de Paulo Freire; "Tio Rocha", sempre professor das poéticas coloniais, leitor e escritor viajante entre letras e leis.

15 Morada de Pedro Braga, pianista internacional e do arqueólogo inglês Mr. Gooland, tradutor da versão em inglês de Macunaíma. Primeira Pousada do Brasil com o projeto aprovado pela EMBRATUR em edifício tombado pelo patrimônio histórico, um casarão de estilo neoclássico do final do século XIX. 
Ela virou uma estrela, a Ursa Maior, como nos fala o poeta Bento enquanto que ele nunca deixará de brilhar num belo horizonte sem fim, ainda que a memória ofusque suas lembranças e reminiscências parnasianas.

Obrigada por acreditarem que escrever, como ler, é preciso. E por terem sido professores, sobretudo incentivadores, numa pátria cuja tradição do escolarizar consta mais no plano do projeto como certificação, no mundo do discurso como políticas públicas, no universo ficcional da escola como instituição e menos na prática pedagógica efetiva de cada dia, a título de incorporação dos saberes necessários para a devida construção da cidadania digna, pelo ofício do aprender.

Por isso ler, como viajar pelas muitas histórias e sonhos de que somos feitos, como nos ensina o poeta Eduardo Galeano, é preciso. Sempre! 


\section{Resumo}

RINALDI, Lucinéa. Entre a Prosopopeia e a Viagem: poética e narrativa por letras coloniais. São Paulo: Tese de Doutorado, Departamento de Letras Clássicas e Vernáculas, Universidade de São Paulo, 2016.

A tese discute, sob a interface da literatura e da história, duas narrativas coloniais produzidas a partir de Olinda. Sugere-se o embarque pelos campos da poética e da viagem e revisita Pernambuco, não no sentido de cantar ou descrever feitos históricos, porém alcançar a percepção do leitor como proposta de se ler um texto épico, outro descritivo mediado por suportes interdisciplinares. Entre a epopeia e o testemunho, propõe-se aqui uma análise dos mundos épico de Bento Teixeira, autor de Prosopopeia e viajado por Henry Koster, autor de Travels in Brazil, traduzido ao português por Luís da Câmara Cascudo como Viagens ao Nordeste do Brasil, por letras necessárias para se ler a paisagem e ver o mundo, mediante o diálogo entre a arte e a cartografia do imaginário. Como passaporte para a leitura, indica-se o embarque pelas fontes luso-brasileiras. Como proposta de chegada, trilha-se o caminho da percepção de composição de mundo colonial pela temática da viagem. A tese alcança questões da contemporaneidade, como leitura e recepção, educação e currículo, educação pública e sociedade, estado social e estado providência para a devida aquisição da cidadania, graças ao direito de aprender conteúdos necessários para a formação digna.

Palavras-chave: Olinda. Pernambuco.Viagem. Educação. Direitos. 


\begin{abstract}
RINALDI, Lucinéa. Prosopopeya and Travels: poetics and narrative through colonial writings. São Paulo: Tese de Doutorado, Departamento de Letras Clássicas e Vernáculas, Universidade de São Paulo, 2016.
\end{abstract}

This thesis debates, under the interface of literature and history, two colonial narratives produced by Olinda. It is suggested boarding in the fields of poetry and voyage and revisits Pernambuco, neither in the sense of singing, nor by describing a sort of historical facts only, though reaching the perception of the reader at present. The purpose here is an invitation to reading theses narratives, not only because of the epic or descriptive approach, but thanks to the contribution and mediation of interdisciplinary areas. Between the epic and the testimony, it proposes a piece of analysis of worlds written by Bento Teixeira, author of Prosopopeia and traveled by Henry Koster, author of Travels in Brazil, translated into Portuguese by Luís da Câmara Cascudo as Viagens ao Nordeste do Brasil, as texts necessary to be read in order to understand the landscape and see the world of the colonial period of Brazil, through the dialogue between art and cartography of the imagination. As a passport to reading, the starting point is indicated by the Luso-Brazilian sources. As strategy of arrival, noticing the perception of the colonial world composed thanks to the theme of the voyage is the path. The thesis reaches contemporary issues, such as reading and reception, education and curriculum, public education and society, social and welfare state for the proper acquisition of citizenship, thanks to the right to learn content necessary for worthy education basis.

Palavras-chave: Olinda. Pernambuco. Voyage. Education. Rights. 


\section{Resumen}

RINALDI, Lucinéa. Entre la Prosopopeya y el Viaje: poética y narrativa por las letras coloniales. São Paulo: Tese de Doutorado, Departamento de Letras Clássicas e Vernáculas, Universidade de São Paulo, 2016.

La tesis analiza, bajo la interfaz de los campos de la literatura y de la historia, dos narrativas coloniales producidas a partir de Olinda. Se sugiere una estratégia de embarque por los campos de la poética y del viaje; vuelve a visitar Pernambuco, no en el sentido del canto épico o por la descripción de hechos históricos basados en la crónica, sino llegar a la percepción del lector moderno. Se propone la lectura de un texto épico, mediada por la herramienta interdisciplinar. Entre el estúdio de la épica y el testimonio, se pensa acá establecer un análisis de dos mundos: uno épico de Bento Teixeira, autor de la Prosopopeya; el otro, viajado y escrito como crónica por Henry Koster, autor de Viajes en Brasil y traducido al portugués, por Luís da Cámara Cascudo, como Viajes al Nordeste de Brasil. Se propone esas obras como letras necesarias para se leer el paisaje y ver el mundo a través del diálogo entre el arte y el imaginario de la cartografía. Como pasaporte para la lectura, se recomienda el embarque por las fuentes luso-brasileñas. Como ruta de llegada, el camino propuesto es pensar, bajo la composición de la percepción del mundo colonial, el tema del viaje. La tesis llega a los problemas contemporáneos, tales como lectura y recepción de crónicas coloniales, educación y currículo, educación pública y sociedad, estado social y estado de bienestar para la búsqueda de la ciudadanía plena, gracias al derecho de adquisión de aprendizajes necesarios para la educación digna.

Palabras clave: Olinda. Pernambuco. Viaje. Educación. Derechos. 


\section{SUMÁRIO}

I: Apresentação

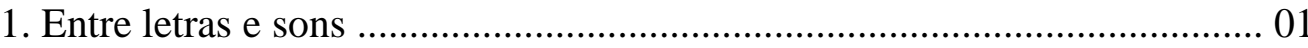

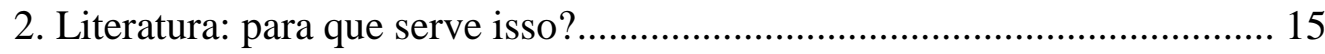

3. Entre a épica e a viagem .................................................................... 18

II: Embarque

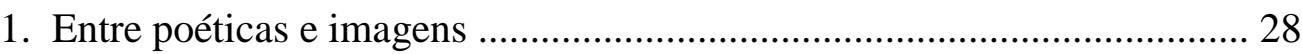

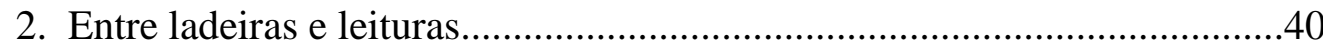

III: Paisagem

Entre a tela e a escrita

IV: Mundos:

1. Épico 59

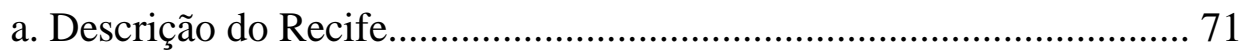

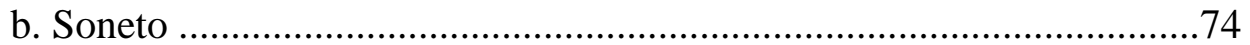

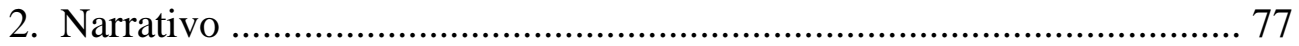

V: A Prosopopeia da viagem por letras coloniais ................................................ 96

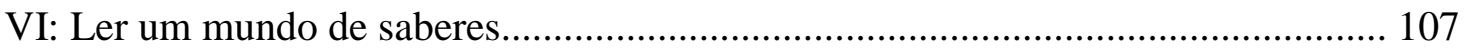

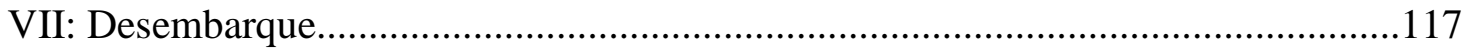

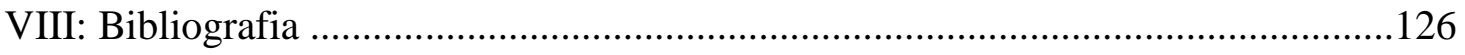




\section{Apresentação}

\section{Entre letras e sons}

Na memória, é fácil compor

Todo o dia, seja onde for:

Sentado, escritor, numa mesa,

Ou andando, entre a angústia e a pressa ${ }^{16}$.

Cursar as disciplinas, organizar as leituras, compor os trabalhos, promover a pesquisa e a escrita da tese ${ }^{17}$ foi, na medida do possível, um trabalho árduo, porém gratificante, no sentido de que a investigação científica procura ler letras coloniais mediante condicionantes históricas, sem perder de vista questões do presente.

Pensar os pressupostos que envolvem o debate quanto aos estudos coloniais, com o propósito de se levantar as fontes, a partir do campo dos estudos literários, com finalidade de se ler e reler letras coloniais foi, preliminarmente, a estratégia pensada, ao percebermos a necessidade de se pesquisar narrativas que suscitam muitos diálogos com outros campos dos saberes, como o histórico, o geográfico e o antropológico.

Assim como um poema se faz aos poucos, segundo João Cabral de Melo Neto, caminhamos com a escrita de uma tese entre os muitos emaranhados que envolvem leituras e reflexões acadêmicas, pensando para quem pesquisamos e para

16 MELO NETO, João Cabral de. Um poema sempre se fazendo. Cenas da vida de Joaquim Cardozo. In: Poemas Pernambucanos. Rio de Janeiro: Nova Fronteira, 1999, p. 214.

17 “A tese deve ser entendida como uma ocasião única para fazer alguns exercícios que nos servirão por toda a vida”. ECO, Umberto. Como se faz uma tese. São Paulo: Editora Perspectiva, 2000. Pg.15 e 19. 
quem escrevemos, bem como qual é o lugar da produção acadêmica quando, diariamente, vivenciamos o grande abismo cultural existente entre a academia e os bancos da escola.

Nesse sentido, Umberto Eco nos fala que escrever uma tese, de certa forma, é como se escrevêssemos um livro, uma espécie de exercício de comunicação que presume a existência de um público, fato esse que nos faz pensar quanto ao lugar da escrita da tese, para além do olimpo da universidade, uma vez que vivenciamos a realidade da escola pública, nossa práxis diária do comunicar saberes para um público cada mais heterogêneo, uma realidade presente nos bancos da escola, e que a academia conhece sob o véu da teoria.

Partimos da escolha de se catar as fontes, as letras, ainda que não belas, no sentido de se recolher escritos, ainda que desconhecidos ou não lidos como literatura ou como fonte historiográfica, como que se cata feijão, aos grãos, como nos ensina o poeta João Cabral de Melo Neto ${ }^{18}$, percorrendo letras desperdiçadas por parte da crítica literária ou da historiografia canônica, letras que boiaram como ruínas porque "menores", porque naufragaram no esquecimento porque "regionais".

Catar feijão se limita com escrever: jogam-se os grãos na água do alguidar e as palavras na folha de papel; e depois, joga-se fora o que boiar. Certo, toda palavra boiará no papel, água congelada, por chumbo seu verbo: pois para catar esse feijão, soprar nele,

e jogar fora o leve e oco, palha e eco.

18 Melo Neto, João Cabral de. Obra Completa. Rio de Janeiro: Nova Aguilar, 2006. 
Assim, para se estabelecer o processo da tese em construção, recuperamos a escrita dos capítulos, tecidos graças às leituras, aos debates e aos estudos arrolados e compartilhados nas disciplinas cursadas, como estratégia de se perceber como ler e interpretar letras coloniais que suscitam aprendizagens e saberes para além do cotejo do vocábulo ou do gênero textual vigente.

Quanto às narrativas arroladas, ainda que a investigação sobre questões lexicográficas, de estilo textual ou de tradutibilidade pertençam à seara do campo literário, optamos por uma teia de investigação científica que promova leitura e percepção dos textos mediante a dialética entre a memória e a história, como ponto de partida, porque pensamos caminhar sob dois paradigmas: num primeiro momento, pensar a literatura como função, em outras palavras, para que serve ler letras, sobretudo coloniais; num segundo, alcançar, por meio do diálogo interdisciplinar, a legitimidade dessas leituras, como necessárias, para a concepção do pensar, como pressuposto para se alcançar nossa percepção enquanto brasileiros.

Buscamos, nesse sentido, pela trilha dos estudos historiográficos, uma espécie de atalho para se compreender, com base na leitura da poética de um texto épico, bem como de uma experiência de viagem narrada, letras produzidas num universo de colonização e ocupação portuguesa nos trópicos, expressas sob o signo da "passagem"19 por um mundo de vivências e experiências ajustadas entre a memória e o testemunho.

Assim, investigamos, num primeiro momento, a visão estética de um mundo ficcional composto, graças à leitura de um poema épico feito por um cristão novo, Bento Teixeira, autor de Prosopopeia, conhecido como o primeiro poeta brasileiro, preso pelo Tribunal do Santo Ofício, na capitania de Pernambuco em 1595 e morto nos cárceres da Inquisição em Portugal $^{20}$.

19 "Dir-se-ia que, aqui, a Colônia é simples lugar de passagem, para o governo como para os súditos. É, aliás, a impressão que levará Koster, já no século XIX, de nossa terra.” HOLANDA, Sérgio Buarque de. O Semeador e o Ladrilhador. In: Raízes do Brasil. São Paulo: Companhia das Letras, 2005. P.99.

20 "Um homem de extraordinária erudição, em um ambiente sem escolas, livros e cultura. Conhecê-lo nos traz um quadro da vida colonial, até agora pouco revelado, pois nela se escondia uma população 
Num segundo momento, estudamos as muitas descobertas enunciadas pela narrativa, como registro do testemunho e da experiência de Henry Koster ${ }^{21}$, um inglês que leu, viveu e escreveu sobre o Brasil, mediante a construção de uma cartografia traçada pela memória construída entre o viajar, o conviver e o escrever, livro traduzido por Câmara Cascudo como Viagens ao Nordeste do Brasil ${ }^{22}$, com a finalidade de imaginar excertos de mundo mediante a prosopopeia da viagem que a leitura nos proporciona pelo advento da máscara ${ }^{23}$.

Ler essas narrativas convida-nos a realizar uma espécie de reembarque ao plano do imaginário, do encantado e do afetivo para um mundo já experimentado pelas

culta, heterodoxa e descrente do Catolicismo." RIBEIRO, Eneida Beraldi. Bento Teixeira: Inquisição e Sociedade Colonial. Porto Alegre, Revista do ICJMCRS, V.4 n.1 (jan-jun) 2012.

21 "Ao entregarmos ao público ledor mais uma edição da obra clássica de Henry Koster, que recebeu o título em português de Viagens ao Nordeste do Brasil, julgamos por bem chamar a atenção da crônica desses viajantes no registro da evolução da paisagem brasileira nesses últimos séculos." E: "De todos os que se aventuraram em percorrer os sertões brasileiros, mesmo entre aqueles que apenas registraram aspectos de nosso litoral, foi o inglês Henry Koster o que melhor soube expressar os sentimentos de nossa gente." SILVA, Leonardo Dantas. Koster, o Mais Fiel Retratista da Paisagem. In: http://www.onordeste.com/portal/. Acesso feito em 02 de fevereiro de 2016.

22 "Por que não se resolve a ver o Brasil que o Catete esqueceu? [...] Venha ver estas coisas. Casas, vaqueiros, lobisomens, matutos, anedoteiros, governadores, capitães-mores, jornais - dente de cação, autos Fordes... venha! E as Igrejas da Bahia e Recife e Olinda... Tanta coisa!” CASCUDO, Câmara Luís. Carta a Mário de Andrade, Natal, 19 de maio de 1925. Câmara Cascudo e Mário de Andrade. Cartas, 1924 - 1944. Organização e notas de Marcos Antonio Moraes. São Paulo: Editora Global, 2010.

23 Sabemos que a prosopopeia, na condição de figura de linguagem, também é conhecida pelos nomes de personificação, animização e antropomorfismo e que seu alcance significa atribuir vida, atitudes ou sentimentos a seres inanimados, pessoas já falecidas, animais ou, fenômenos da natureza. A origem etimológica da palavra prosopopeia parte do grego 'prósopon', que significa pessoa, face, rosto e a união desse termo com 'poeio' significa "finjo", sugerindo-nos o significado de rosto fingido, daí o conceito de máscara. http://www.figurasdelinguagem.com/prosopopeia/. Acesso em 02 de maio de 2015. 
viagens realizadas a Pernambuco, sobretudo a Olinda 24 : "Viver é ir entre o que vive", como nos lembra João Cabral de Melo Neto, em O cão sem plumas ${ }^{25}$.

IV Discurso do Capibaribe

Aquele rio

está na memória

como um cão vivo

dentro de uma sala.

$[\ldots]$

Um cão, porque vive,

é agudo.

$O$ que vive

não entorpece.

$O$ que vive fere.

O homem,

porque vive,

choca com o que vive.

Viver

é ir entre o que vive.

O que vive

incomoda de vida

o silêncio, o sono, o corpo

que sonhou cortar-se

roupas de nuvens. ${ }^{26}$

Ler a poética pela lente dos espaços, entre o escrito e o experimentado, para além dos documentos, pelas letras coloniais produzidas enquanto épica ou crônica, não

24 “ [...] pelo espírito aguerrido do seu povo, responsável pela suserania da coroa portuguesa nas capitanias do Norte, antes integrantes do Brasil Holandês (1630-1654), a contribuição da gente de Pernambuco às letras e às artes nos dois primeiros séculos da colonização ainda está por ser estudada". SILVA, Leonardo Dantas. Bento Teixeira e os outros pioneiros das Letras em Pernambuco. Ci. \& Tróp, Recife, v 26, a. 2, p. 303-31 0, juL/dez., 1998.

25 MELO, Neto. João Cabral. O Cão sem Plumas. In: Poesias Completas (1940-1965) José Olympio 1979.

26 MELO Neto, João Cabral de. Poemas Pernambucanos. São Paulo: Editora Nova Fronteira, 1999. 
com o olhar pronto, historiográfico, na condição de aprendiz viajante, foi a estratégia escolhida como rota para se navegar pela escrita, partindo-se da mítica Olinda.

Não há perto do Recife melhor situação donde se gozar a paisagem deste pedaço do Brasil cheio de coqueiros e de igrejas antigas, de cajueiros e casas velhas, de mangueiras vindas da Índia e de jangadas partindo da praia para o mar, do que os altos de Olinda. ${ }^{27}$

A exemplo do percurso que fizemos no mestrado, com base na escrita dos cronistas investigados, optamos por encaminhar as leituras, conduzir a pesquisa com finalidade de encontro ao universo plurissemântico de aprendizagens: a descoberta da paisagem, o contato com os diversos falares e cantares, a percepção dos pontos de cultura, patrimônios imateriais, com o propósito de aquisição da melhor percepção e ressignificação de um mundo lido, uma espécie de redescoberta: nossa alma, aos poucos, já se tornava um pouco mais pernambucana, sobretudo a cada carnaval vivenciado entre as ladeiras e o mar, entre os muitos escritos compartilhados, guardados entre a memória, a viagem e a leitura.

Cabe por hora, redescobrir o ponto entre a cultura, o costume e a poética que o contorno interdisciplinar nos sugere, com base na leitura das letras coloniais, como uma possibilidade de percepção da cartografia da paisagem e do retrato da Terra, bem como da circulação dos discursos, por meio de um gênero de escrita, ainda que imitação, o qual nos auxilie a pensar uma possibilidade de interpretação, tradução e percepção do caldeirão de saberes a ser decifrado entre o mundo épico cantado por um cristão novo e outro contado por um estrangeiro.

Pelos caminhos narrados por Koster, necessário se fez olhar para Pernambuco, lugar onde muitas questões de um Brasil Colônia se colocavam, sobretudo, a circulação de culturas; buscar um objeto de investigação mais literário do

27 FREYRE, Gilberto. Olinda: $2^{\circ}$ Guia Prático, Histórico e Sentimental de Cidade Brasileira. São Paulo, Global, 2007, P. 27. 
que geográfico foi preciso. Assim, alcançamos Bento Teixeira e com ele, partimos para a escrita dessa viagem pelas letras coloniais.

Navegar é sempre preciso, por muitos campos: pelo geográfico, para entender a cartografia do imaginário; pelo antropológico, para perceber as muitas vozes e diálogos entre textos, sobretudo com a antropofagia; pela educação, uma vez que como professora primária e de língua portuguesa, realizamos pesquisa acadêmica com olhos de quem parte do mundo da escola, do trabalho de onde sai o fomento para bancar o custo da pesquisa, como livros, viagens, muitos dias de trabalho descontados; pela filosofia, porque poética, estética e linguagem são ingredientes necessários para repensar o processo de reflexão acadêmica, sem perder o tino, no sentido de que navegamos pelo plano literário cuja bússola aponta para a necessidade de se traduzir linguagem e pensamento de um mundo diferente daquele que se lê e se vê lá fora; e, finalmente, pelo direito, porque incluir no debate acadêmico direito e educação, é uma necessidade acadêmica, diante das grandes questões que acompanhamos em tempos da "pátria educadora", ao presenciamos o processo de sucateamento e de desmonte das instituições públicas e, sobretudo, a fumaça de privatização do ensino universitário público.

Não nos fechamos no mundo acadêmico ${ }^{28}$, optamos por pesquisar e olhar pela janela, até porque vivenciamos a realidade da escola pública brasileira, foi uma opção necessária em tempos de acontecimentos únicos, como protestos, protagonismo estudantil, mudança curricular, flexibilização e terceirização do ofício do ensinar e não menos a maior catástrofe ambiental, nossa lama de cada dia.

28 "Toda lógica do funcionamento de um sistema que detém o monopólio de sua própria reprodução, obriga-o a assumir até o limite a tendência para a conservação resultante de sua função de conservação cultural. Reforçando por sua própria inércia os efeitos da lógica característica do processo de canonização, o sistema de ensino contribui para manter a defasagem entre a cultura produzida pelo campo intelectual e a cultura escolar, "banalizada" e racionalizada pelas e para as necessidades de inculcação, isto é entre os esquemas de percepção e de apropriação exigidos pelos novos produtos culturais e os esquemas efetivamente manejados a cada momento pelo "público cultivado." BOURDIEU, Pierre. $O$ Mercado de Bens Simbólicos. IN: A Economia das trocas Simbólicas. São Paulo: Editora Perspectiva, 2013. P. 123. 
Portanto, o atalho escolhido foi tecer a escrita da tese, na condição de pesquisadora que mantém os pés na escola, com mãos que lecionam há quase três décadas e olhos que percorrem a letra e a lei, herança de uma formação jurídica, para promovermos uma escrita a qual pretende ponderar o estudo da poética, sem perder de vista costumes e práticas estéticas em circulação, necessários ao diálogo acadêmico, uma vez que concebemos esse pressuposto como fundamental para o estudo e pesquisa.

Nesse sentido, nossa intenção acadêmica é apresentar uma tese que parta do Departamento de Letras Clássicas e Vernáculas e dialogue com os campos semânticos das Ciências Humanas, de forma interdisciplinar quanto à sua gênese, nomenclatura e finalidade.

Conciliar trabalho e pesquisa, de fato, não foi uma tarefa fácil; contudo, uma luta diária que exige dedicação, força de vontade e superação para se realizar uma escrita no silêncio dos sons, com resgate das imagens lidas e experimentadas, poéticas articuladas entre a épica e a cartografia do imaginário, como um retrato capaz de traduzir a paisagem, física ou humana, por letras coloniais cada vez mais despercebidas pela academia, ignoradas por parte da crítica, ausentes do cânone de leitura, adormecidas como ruínas, mas que devem ser percebidas como que integrantes do repertório colonial, na condição de "corpo místico", como nos esclarece o Professor Hansen:

A tópica do corpo místico do Estado é fundamental nos discursos coloniais, desde os tempos de Nóbrega, Anchieta, Luís da Grã e Fernão Cardim, no século XVI, até os de Tomás Antônio Gonzaga, na segunda metade do século XVIII. A tópica também comparece em tratados arquitetônicos que doutrinam modos de ordenar o espaço urbano como alegoria do corpo político do Estado. ${ }^{29}$

Dividida entre o cansaço exaustivo de 12 horas de trabalho diário e a necessidade de se olhar para o objeto acadêmico, o percurso da tese parte da concepção

29 HANSEN, João Adolfo. Letras Coloniais e Historiografia Literária. Rio de Janeiro: UERJ, 2015. 
de catar as palavras como se cata feijão, aos grãos, como se costuram chitas e prendas, como se emendam fuxicos, para se bordar e rendar a escrita das ideias em processo.

Felizmente, a composição da escrita como forma de escape, ainda que construída entre a "ausência" e a "pressa" de que nos fala João Cabral, diante de instantes de quase desespero, desassossego com tantas obrigações a cumprir ou ausência de compreensão ou colaboração, porque "pesquisar compromete o ofício do ensinar;" ou ainda, "pesquisar vozes coloniais, literatura, barroco pra quê?”; "Quem se interessa por isso?"; "O que você ganha com isso?”; "Para que serve isso?"; "Com certeza, isso não dá retorno”.

De um lado, o convívio constante de pilhas de livros para ler e anotar, disciplinas a cursar, seminários, artigos e trabalhos para serem feitos, ou ainda, escrever os primeiros rascunhos da tese e, por outro, provas, trabalhos e redações para corrigir, atividades e aulas para se preparar, para um público alvo de aproximadamente 200 alunos atendidos por dia, além de coordenadores e diretores, inserir dados "on-line" porque o professor hoje cada vez mais trabalha na virtualidade, com uma jornada desenvolvida mediante condições insalubres, porque ensinar é cada vez mais um desafio, tornou-se, de fato, um exercício de esforço e superação; acrescente-se a isso, um sem número de contas a pagar, uma vez que deixar de lecionar na escola para estudar e pesquisar em casa ou na biblioteca, com frequência, não era possível e, finalmente, um descrédito significativo quanto ao ofício do pesquisar, como atividade reconhecida, dentro e fora dos muros da escola.

Um exemplo disso, muito ilustrativo, pode ser descrito tanto pela circunstância do tempo, ausente, escasso e não sequencial para o estudo e a pesquisa quanto ao espaço, leituras e reflexões realizadas entre lugares e momentos esparsos, bem como pela ausência do ambiente ideal, acústico, em casa: ler e escrever somente com o uso constante de protetor auricular. Foi preciso buscar, na madrugada ou no quase amanhecer, o refúgio para o silêncio e concentração, como tentativa de esconderijo $^{30}$, fuga como condição de escape para que a pesquisa e a escrita se desenvolvessem.

30 O crítico Erich Auerbach, no capítulo sobre Montaigne, nos fala sobre o “esconderijo", a estratégia usada pelo escritor de se isolar diante de um mundo com tantas obrigações a cumprir: "[...] Mas se o 
Estudar nas altas horas da noite ou na aurora do dia, após lecionar em duas escolas públicas, com uma jornada de trabalho desgastante, cumprida efetivamente em salas de aula, com um público cada vez mais heterogêneo e, na volta, após um longo dia de trabalho, vencer toda forma de ruído presente para se encontrar o silêncio adequado, superar o cansaço, encurtar o sono, acreditar no objeto pesquisado, buscar novas leituras, perceber o mundo para além da academia - tudo isso foi preciso, como exercício de credibilidade e de superação.

A escrita tecida no alvorecer ou na calada da noite, no silêncio garimpado como ouro, peneirando palavras, ideias e conceitos, fruto dos debates realizados nas disciplinas cursadas e nas vivências adquiridas pela experiência da viagem, entre a Costa do Descobrimento e a Pernambuco de Bento Teixeira, de Henry Koster e de Alceu Valença, redescoberta pelos muitos carnavais, sem perder de vista a contribuição de Gilberto Freyre ${ }^{31}$, no sentido de se pensar o Brasil, pela literatura e pela arte, quanto ao campo das aprendizagens e singularidades integrantes desse caldeirão de saberes, conteúdo fundamental de base para a aquisição do conhecimento e repertório construtores para a cultura de paz.

fardo se fizesse pesado demais se tais obrigações viessem a lhe exigir muito, estaria disposto a abandoná-las. $O$ verdadeiro objeto de sua defesa é seu cerne interior, o esconderijo de seu espírito, a "arrière-boutique" que soube conservar para si." AUERBACH, Erich. O Escritor Montaigne. In: Ensaios de Literatura Ocidental. São Paulo: Livraria Duas Cidades / Editora 34, 2007. P. 146.

31 "Freyre, enfeitiçado pelo velho Recife, alumbrado, à Manuel Bandeira, por "amuletos culturais" que bem preservam relíquias da saudade. E: O Nordeste fascina pelas suas histórias e estórias. O Congresso Regionalista de 26, no Recife, buscou atender a esse leque de variações, sem, em momento algum, render homenagens a sectarismos. Pelo contrário, alertou veemente para a necessidade de harmonizar tradições as mais diversas - do exótico ao simples, do festivo ao bucólico, do provinciano ao cosmopolita. Entre o Norte e o Sul, entre o Leste e o Oeste, há que se clarear o "degradée" de hábitos e costumes de modo a instigar "fragmentos" num todo brasileiro e nacional". QUINTAS, Fátima. Apresentação. In: FREYRE, Gilberto. Manisfesto Regionalista. Recife: FJN / Editora Massangana, 1996. P.16, 17. 
Pois de regiões é que o Brasil, sociologicamente, é feito, desde os seus primeiros dias. Regiões naturais que se sobrepuseram, regiões sociais. ${ }^{32}$

A literatura e a arte não pertencem apenas ao domínio da crítica literária ou de arte: incidem também no domínio do sociólogo, do historiador social, do antropólogo e do psicólogo social. Porque através da literatura e da arte é que os homens parecem mais projetar a sua personalidade, e, através da personalidade, o seu éthos nacional. Através das artes eles descrevem as condições mais angustiantes do meio em que vivem e refletem os seus desejos mais revolucionários. ${ }^{33}$

Viajar foi preciso para se perceber esse mundo lido, cantado em forma de épica ou de diário, descrito como testemunho da história e dos costumes. Escrever na madrugada ou ainda nas primeiras horas da manhã, apontamentos com base nas leituras e na escrita dos afetos de uma Olinda desvendada pela experiência do encontro, entre mundos lidos e experimentados, foi uma prática necessária.

Assim, alcançamos o Bicho Maluco Beleza, poeta, num encontro literário realizado em novembro de $2015^{34}$; contamos-lhe como se dava a pesquisa e na sequência, pedimos-lhe permissão para escolher um poema que melhor traduzisse esse momento de composição da escrita, entre os silêncios dos sons e o alcance da memória dos muitos guardados, sobretudo das vozes de uma Olinda ${ }^{35}$ revisitada a cada sábado de Zé Pereira ${ }^{36}$.

32 FREYRE, Gilberto. Manifesto Regionalista. Recife: IJN, 1976. P, 56.

33 DANTAS, Cauby. Gilberto Freyre e José Lins do Rêgo: diálogos do senhor da casa grande com o menino do engenho. Campina Grande: UEPB, 2015.

34 FLIPORTO, sobre Fernando Pessoa.

35 "Em Olinda há o silêncio e a tranquilidade que favorecem os passos perdidos dos que se comprazem nessa contemplação do passado e dos vestígios impregnados de tão nobre melancolia. BANDEIRA, Manuel. Velhas Igrejas. In: Crônicas da Província do Brasil. São Paulo: CosacNaify, 2006. P. 69.

36 Sábado de Zé Pereira, sábado de carnaval nas ladeiras de Olinda. Há notícias de manifestações carnavalescas em Pernambuco desde os meados do século XVI: “Uma das primeiras pistas aparecem em 
OLINDA REVISITED ${ }^{37}$

Poucas cidades ainda

(sem falar nas igrejas

e úteros matriarcais

e bacias maternas)

podem dar a quem passa

a intimidade aquela

de quem vive uma casa

como outra matriz terna, habitando paredes,

chãos de tijolo, telhas,

rebocos que respiram

anchuras, estreitezas,

mais a porosidade

das quartinhas de terra

que à água dão o gosto

do barro que nos era.

De fora de uma casa

de uma cidade dessas,

o estranho-de-mais-longe

sente a morna franqueza

que expressa sua fachada

(mesmo quando se fecha).

Hoje-em-dia em Olinda,

e não só nas igrejas,

viver-se de alma e corpo,

se pode quem se veja:

se pode em qualquer casa

e contemplando-a apenas;

quem visita tal casa

não só passeia nela:

geralmente se casa

com ela, ou se amanceba.

Alceu, o poeta das cidades, da solidão, do amor, do tempo e da saudade ${ }^{38}$, necessário se fez buscar o refúgio na madrugada para deixar o pensamento fluir e a

documentos do arquivo da Santa Inquisição. Foi quando a beata Maria d' Almeida "dedurou" um seu desafeto, o cristão novo Diogo Fernandes ao Inquisidor Heitor Furtado de Mendonça, do Tribunal do Santo Oficio, então visitando a colônia: " porque, no dia seguinte ao ENTRUDO - 4a feira de Cinzas dia de abstinência, aquele judeu teria servido carne de porco aos seus trabalhadores". Em 1809, após passar por Pernambuco, o viajante Henry Koster descreveu, num jornal de Londres a sua experiência nas Festas de entrudo do Recife Colonial. BONALD Neto, Olimpio. Os Gigantes Foliões em Pernambuco. Recife: Companhia Editora de Pernambuco, 2007.

37 MELO Neto, João Cabral. A escola das facas. Auto do Frade. Rio de Janeiro: Alfaguara, 2008. P.53.

38 Valença, Alceu. O Poeta da Madrugada. Lisboa: Chiado Editora, 2015. 
escrita acontecer, aos poucos, imagens catadas na memória e nos sonhos, agora revividos entre as letras do frevo ${ }^{39}$, do maracatu ${ }^{40}$, da ciranda de $\mathrm{Lia}^{41}$ e a leituras de Bento e Koster, experimentadas em cada ladeira ${ }^{42}$, entre a Sé e a Misericórdia.

\author{
A solidão é fera, a solidão devora, \\ É amiga das horas, prima irmã do tempo \\ E faz nossos relógios caminharem lentos, \\ Causando um descompasso no meu coração. \\ A solidão dos astros, a solidão da lua, \\ A solidão da noite, a solidão da rua. ${ }^{43}$
}

39 "Pernambuco tem uma dança que nenhuma terra tem", os versos que iniciam o frevo-canção "É Frevo, Meu Bem", de Capiba, transcendem à mera manifestação ufanista do compositor. " Diferente da grande maioria dos gêneros da música popular brasileira, o frevo tem origem em um único estado: Pernambuco." TELES, José. Do Frevo ao Manguebeat. São Paulo: Editora 34, 2012.

40 “Tais manifestações culturais são aqui entendidas como atuais e construídas no presente por homens e mulheres que operam com práticas e costumes eivados de heranças do passado, mas devidamente ressignificadas e sintonizadas com seus anseios, ideias e visões de mundo." E: "Este artigo é também uma tentativa de elucidar parte dos sentidos existentes nas toadas dos maracatus e o que elas poderiam representar para os maracatuzeiros que compuseram tais letras, percebendo-as também como dotadas de valor literário e artístico [...]." LIMA, Ivaldo Marcio de França. Toadas de Maracatu e Músicas de Afoxé: Ressignificação de Valores, Sentidos e Tradições na Cultura Afrodescendente Pernambucana. Feira de Santana: A Cor das Letras, UEFS, n. 8, 2007.

41 "Minha ciranda não é minha só / Ela é de todos nós", Capiba. Maria Madalena Correra do Nascimento, conhecida como Lia de Itamaracá trabalhou como merendeira numa escola pública da rede estadual de ensino e nas horas vagas dedica-se a compor e cantar ciranda, "um Dom de Deus e uma Graça de Iemanjâ", cocos de roda e maracatus. http://basilio.fundaj.gov.br/. Acesso em 10 de março de 2016.

42 "Caminhar pela cidade, descompassar um caminhar previamente instituído, talvez nos permita vislumbrar não só outras cidades, mas, sobretudo, outra gente, outra humanidade que caminha num espaço aberto, rastros nômades que muitas diásporas nunca conseguiram apagar e poucos textos conseguiram perceber". LIMA, Ivaldo Marciano de França. Maracatus do Recife: novas considerações sob o olhar dos tempos. Recife: Edições Bagaço, 2012. P. 18.

43 VALENÇA, Alceu. O Poeta da Madrugada. Lisboa: Chiado Editora, 2015. 
A escrita na solidão, a escuta das muitas vozes necessárias para a elaboração de um trabalho tecido aos poucos, mediante o corte e o recorte de retalhos, com base na poética da crônica lida e na viagem experimentada, suas costuras e emendas, uma redação fruto de uma escrita tecida a partir do contato, provocada na leitura das narrativas e recolhida pelo repertório de saberes, graças às disciplinas cursadas, resultante da contribuição da pluralidade de conversas e práticas nas ladeiras de uma Olinda revisitada por meio dos seminários, debates e discussões dos ensaios, bem como pela leitura dos poemas, artigos, crônicas e diários.

Foi preciso buscar por ti, Olinda, nesse universo, a poética necessária para a pesquisa: como ler Bento Teixeira e Henry Koster por seus escritos, não pelos processos de defesa ou de historiografia da terra e das gentes; como pensar uma leitura possível da épica e da viagem pelo ponto da cultura e, ainda, como escrever uma tese na solidão da cidade grande.

Assim, necessário se fez arrolar muitas vozes: entre o poeta Bento e o viajante Koster; entre o trovador Alceu e o pensador Gilberto Freyre; e resgatar, pela experiência das nossas vivências, a possibilidade da escrita justificada pela redescoberta de um inventário de curiosidades a cada carnaval vivenciado, a cada Feira Literária Internacional de Pernambuco revisitada. Afinal, estamos na terra de Lampião, de Luís Gonzaga, de Mestre Salustiano, de Naná Vasconcelos e do Homem da Meia Noite. Não é pouca coisa... 
I.2 Literatura: para que serve isso? ${ }^{44}$

Por que amo a literatura?

Porque ela me ajuda a viver.

Todorov $^{45}$

Para que serve isso?

A literatura precisa servir?

Ela paga as contas? Não.

Ela vai mudar alguma coisa? Não.

Ela muda a vida? Não.

Talvez ela possa mudar o olhar

Ainda que para muitos

ela de nada vale.

A literatura nos permite

fugir

44 Escrito em outubro de 2015 e revisitado em abril de 2016 entre a angústia e a pressa de que nos fala João Cabral de Melo Neto, em Um poema sempre se fazendo, diante da pergunta que não quer calar, tantas vozes numa mesma ladainha, a nos indagar: "Pra que serve isso que você está fazendo?” de ver o calendário voar, de sentir as palavras e as ideias escorrerem pelas mãos como água, a procura da outra margem do rio, como porto seguro para que a tese encontre sua âncora, diante de um mar de saberes circunavegantes do ler e do escrever entre o poeta e o viajante.

45 Todorov, Tzvetan. A Literatura em perigo. São Paulo: Difel, 2009. P23. 
da burrice

da mediocridade

da loucura dos tempos

viajar

por escritos

que nos permitem

dialogar

entre séculos.

A literatura serve

para que se perceba que

somos capazes de ler

e de decifrar o mundo

que nos acolhe

para o jogo do servir.

A literatura nos recolhe

para o ócio criativo do pensar.

A literatura serve para não enlouquecer...

Para que a vida

não se entorpeça

e não tropece 
na inutilidade do servir

para o nada

de que vale

o vale tudo

a que chamamos de mundo

vasto, mundo

como nos ensina e acolhe o Poeta.

Assim somos,

náufragos de uma viagem

que caminha entre o ponto

em que estamos

e o outro que pensamos buscar

na imensidão do nada

a que convencionamos nomear como universo. 


\section{3. Entre a Épica e a Viagem}

Estrondam em Ti as Iaras

Desde Bilac

Somos internacionalistas e portugueses júniors

Gostamos de Camembert, do Nilo, de Frinéia e de Marx

Carvões do mar

Náufragos entre sustos e paisagens

- "I don't Know my elders!"

Desde Gonzaga

Somos pastores e desembargadores

Desde a Prosopopeia

Somos Brasileiros. ${ }^{46}$

Nas considerações finais da dissertação de mestrado defendida em 2007, foram pontuadas muitas questões que motivaram a continuidade dos estudos sobre narrativas produzidas no Brasil Colônia, alcançando, preliminarmente, o propósito da presente investigação, a saber: promover o pensamento, a reflexão e o diálogo, mediante a análise, dos pressupostos necessários para se arrolar, do ponto de vista historiográfico e, sobretudo, o literário, o máximo tesouro sobre a terra e a gente do Brasil, a partir da concepção de caminho traçado, mediante a leitura de um poema e de uma narrativa.

Nesse sentido, uma abordagem interdisciplinar se faz necessária, dada às grandezas das muitas vivências por meio das viagens, histórias e diálogos que teceram, sob a perspectiva do retrato, o grande banquete cultural, o qual tenta traduzir para o mundo o que é o Brasil, com base na sua formação, o ponto de encontro de povos que motivaram a concepção de uma cultura sob o signo da alteridade.

46 Fonte Andrade, Oswald. O Santeiro do Mangue e Outros Poemas. São Paulo: Editora Globo, 1991. 
Nas aulas realizadas com o professor Hansen, na condição de aluna ouvinte, no curso sobre Representação, durante o processo necessário que precisa comungar reminiscências pensadas entre a dissertação tecida e a tese em construção, muitas questões foram propostas no sentido de se pensar: o que leva um aluno do curso de letras a estudar hoje, em pleno século XXI, a poética de um texto colonial?

Em outras palavras, o que desperta a vontade acadêmica de se ler e analisar, com base em outros campos do conhecimento, a narratologia contida num poema, com linguagem vernacular, elaborada por um autor que transitou entre mundos, que arrolou a África ao mesmo tempo em que inseriu o Brasil no contexto mundial, que aos poucos configurava a cartografia colonial a partir da circulação de múltiplos saberes, agregando uma parte do Brasil, aqui no caso, a Nova Lusitânia, na geopolítica histórica do mito (Sebastianismo), por Bento Teixeira ${ }^{47}$, um Autor que se concebia como judeu, mas que no Novo Mundo precisa se travestir como cristão novo e que traça, pelos mares das belas letras ${ }^{48}$, um poema épico ${ }^{49}$ ao molde camoniano, a Prosopopeia ${ }^{50}$ dirigida a Jorge d'Albuquerque Coelho, Capitão e Governador de Pernambuco.

47 "Um autor de biografia obscura", segundo Afrânio Coutinho, não nascido em Pernambuco, mas em Portugal, “cristão novo, natural da cidade do Porto." Segundo o Autor, Bento veio para a Bahia com a família, por volta de 1580, frequentou os estudos do Colégio dos Jesuítas. Em 1586, fixou-se em Pernambuco, onde exerceu o magistério, "adquirindo grande cabedal de conhecimentos. Casado, assassinou a esposa. Era homem de maus costumes e língua solta." COUTINHO, Afrânio. A Literatura no Brasil. 2. ed. Rio de Janeiro: Editorial Sul Americana S.A., 1968. Vol 1, p.179.

48 Quanto ao poder da literatura, lembramos a seguinte definição clássica: A primeira é a definição clássica que permite a Aristóteles reabilitar a poesia em nome da boa vida. É graças à mimesis - traduzida aqui por representação ou por ficção, de preferência a imitação - que o homem aprende, ou seja, da literatura entendida como ficção.” In: COMPAGNON, Antoine. Literatura Para Quê? Belo Horizonte: Editora UFMG, 2009.

49 Segundo Afrânio Coutinho, a imitação da épica camoniana foi aqui inaugurada por Bento Teixeira, “adotando o metro heróico e o mesmo sistema estrófico de Os Lusíadas, com uma linguagem arremedo da língua épica camoniana." Para o Autor, "Bento Teixeira filiou-se à corrente dos imitadores mais pacíficos do grande mestre.". Afrânio entende que este "servilismo formal e expressional" do Autor, bem como "a pobreza de concepção do texto", "isenta-o de qualquer importância literária; porém, sob o aspecto histórico, o poema possui uma significado muito grande, "para o estudo da fase infantil da literatura nacional.” E ainda: “Trata-se não apenas do primeiro livro escrito sob a influência humanista, 
Entretanto, pretende este texto a comunicação com outros campos do conhecimento e, sobretudo, partir a escrita da tese pela Prosopopeia, de Bento Teixeira, no sentido de observá-la como objeto estético, na realização de uma leitura a qual se promova mais uma interpretação de mundo do que um texto que se encerra por ser uma mera imitação ou modelo.

Pensamos aqui no diálogo entre textos que o poema permeia, não na intenção de rotulá-lo a partir de uma classe ou escola literária, uma vez que não cabe aqui pensá-lo como texto fundador da literatura brasileira, mas observá-lo entre a literatura $^{51}$ e a história ${ }^{52}$, finalidade da presente tese, daí a não promoção de uma análise textual meramente histórica ou biográfica.

Temos aqui um poema épico que necessita ser lido a partir de um viés interdisciplinar. Traduzir esse mundo para um leitor contemporâneo, por meio de um

mas também da primeira obra em verso publicada por um poeta do Brasil." E finalmente: "Merece referência ainda o fato de conter o mesmo livro um soneto per ecos ao mesmo Senhor Jorge D’Albuquerque Coelho, escrito em língua castelhana. Talvez seja o primeiro soneto escrito no Brasil." COUTINHO, Afrânio. A Literatura no Brasil. 2.ed. Rio de Janeiro: Editorial Sul Americana S.A., 1968. Vol. 1, p.181.

50 Segundo o Anuário da Academia de Letras, de 1923 "é o primeiro livro formal e impresso de literatura brasileira". Para Afrânio Coutinho, "a Prosopopeia é uma poemeto épico, em versos hedecassílabos, oitava rima, noventa e quatro estâncias." COUTINHO, Afrânio. A Literatura no Brasil. 2.ed. Rio de Janeiro: Editorial Sul Americana S.A., 1968. Vol. 1 , p.179.

51 "Há realmente um momento em que a fronteira existe, por pura, por mínima que seja, por transparente que seja, como um cristal que separa dois ambientes; e a percepção da fronteira é testada pela consciência do escritor, enquanto testemunha." BOSI, Alfredo. Entre a Literatura e a História. São Paulo: Editora 34, 2013. P.223.

52 “A historiografia ocidental se bate contra a ficção;” e "por sua luta contra a fabulação genealógica, contra os mitos e as lendas da memória coletiva ou contra as derivas da circulação oral, a historiografia cria um distanciamento em relação ao dizer e ao crer comuns, além de se instalar precisamente nessa diferença que a credencia como erudita ao distingui-la do discurso ordinário." CERTEAU, Michel de. A história, ciência e ficção. In: História e psicanálise entre ciência e ficção. São Paulo: Autêntica, 2011. P. 45. 
processo de leitura que alcance a narrativa da viagem escrita por Koster e traduzida por Câmara Cascudo é propor um convite para se descobrirem letras coloniais submersas no silêncio dos séculos, na ausência da escolarização digna ou no sequestro dos saberes clássicos rechaçados pelo corpus de aprendizagens universitário.

Para lhes falar do meu trabalho sobre essa ruina arruinada, as letras coloniais dos séculos XVI, XVII, XVIII produzidas no Estado do Brasil e Estado do Maranhão e Grão Pará, repito que é um trabalho arqueológico condicionado pelo seu lugar institucional, a universidade neoliberal que conhecem. Ele passa ao lado da historiografia literária fundamentada nas categorias do contínuo evolucionista do século XIX, como disse e tenta inventar, de modo verossímil, a estrutura, a função, a comunicação e valores dessas letras em seu presente colonial. ${ }^{\mathbf{5 3}}$

Deseja também conversar, respeitando-se o modelo estético em circulação no século XVI, sobre o impacto dessa produção na literatura brasileira, uma vez que crônicas foram produzidas para registrar os espaços percebidos e os personagens encontrados, como motivação para o debate necessário entre o passo e o compasso pendular que a literatura como a história nos permite realizar, o ponto em que nos agarramos como leitores ou pesquisadores, se ficção para a imaginação, a viagem na literatura ou se documento, como meio e finalidade de interpretação de um processo de ocupação da terra e de sua gente ${ }^{54}$.

A intenção aqui se volta a observar que temos em mão um poema e que se encerra com um soneto; portanto, não se pretende analisar um documento ou uma "história" de personagens pernambucanos 55 .

53 HANSEN, João Adolfo. Letras Coloniais e Historiografia Literária. Rio de Janeiro: UERJ, 2015.

54 “Le dernier voyageur est aussi le dernier historien, c'est-à-dire, tout aussi bien le premier: il a vu ce qu'on ne pourra plus voir." HARTOG. François. Régimes d'Historicité. Présentisme et Expériences du Temps. Paris: Éditions Du Seuil, 2003. P. 94.

55 "Para Coutinho, toda análise literária deveria assentar-se sobre fatores internos do texto e não exteriores a ele." Para Ele, a natureza estética, a análise dos termos intrínsecos e a não subordinação à história ou a dados biográficos do autor era o mais relevante a ser observado, pelo leitor, pelo estudioso das letras ou ainda pelo crítico literário, diferentemente do que se propunha como análise literária até então, como se observa na produção crítica realizada por Silvio Romero, José Veríssimo ou Ronald de 
Uma questão aqui se apresenta: como mediar essa leitura para o grande público e como traduzir o ponto em que estamos, entre a história e a cultura que, por meio da estética literária, precisa dar conta de chegar a um leitor que não deve sofrer a adaptação de uma épica canônica, mas aprender a perceber a chave de leitura possível, a concepção de mundo tecida, o tesouro lexical, o repertório cultural em circulação e o diálogo que um texto "histórico" possa traçar com um contexto "presente" por meio da leitura e reflexão que esse mesmo leitor realiza, ao navegar pelos mares das belas letras.

A tarefa aqui reside no pensar quais escolhas entre textos e autores devem acontecer para que se traduza a linguagem vernacular dessa épica e a intertextualidade para uma leitura contemporânea desse mundo seiscentista, bem como quais fontes se comunicam e que podem ser observadas no sentido de se pensar como um leitor hoje acessa as ferramentas de inteligibilidade e compreensão ${ }^{56}$.

Nesse sentido, para que se promova uma reflexão necessária, partindo-se do pressuposto do ofício do historiar e do narrar como método ${ }^{57}$, necessário se faz, num

Carvalho. In: SILVA, Marcelo José. Percurso e Percalços de Afrânio Coutinho na Crítica Literária Brasileira. Rio de Janeiro: Terra Roxa e outras Terras. Revista de Estudos Literários, 2009. Vol.16 .P. 63-71.

56 “O que fazer com as ruínas do passado nas apropriações do presente” se uma questão fundamental que se coloca é discutir o sentido do tempo e da vida na cultura na sociedade neoliberal. "Hoje o capital faz as revoluções estéticas que as vanguardas pretenderam realizar neutralizando a negatividade das artes e das letras no museu” e "o pensamento e a cultura passa a ser coisa que só interessam como instrumentalidade e mercadoria." HANSEN, João Adolfo. Notas Sobre o Barroco. São Paulo: Revista do IFAC, Dezembro de 1997. P.14.

57 Jacques Le Goff, citando Fustel de Coulanges, acerca do privilégio do texto como documento histórico, sobre o primeiro capítulo de Monarchie franque: "Leis, cartas, fórmulas, crônicas e histórias, todas essas categorias de documentos precisam ser lidas, sem omitir uma única...”; e: "o historiador não tem outra ambição que analisar bem os fatos e compreendê-los com exatidão. Não pode procurá-los na imaginação ou na lógica: procura-os e atinge-os através da observação minuciosa dos textos [...]”; $\underline{\mathrm{e}}$ ainda: "o melhor historiador é o que se mantém mais perto dos textos, que os interpreta com mais correção, que só escreve e pensa segundo eles"; e, finalmente, numa lição ministrada na Universidade de Estrasburgo, em 1862: “quando os monumentos escritos faltam à história, ela deve pedir às línguas mortas os seus segredos e, através das formas e palavras, adivinhar os pensamentos dos homens que as falaram. A história deve perscrutar as fábulas, os mitos, os sonhos da imaginação, todas essas velhas falsidades sob as quais ela deve descobrir alguma coisa de muito real, as crenças humanas. Onde o 
primeiro momento, observar a história por meio do testemunho e da narrativa transmitida, no sentido de se acompanhar o ofício do historiador por meio da viagem experimentada $^{58}$.

Ainda, há que se observar a interpretação discursiva que o leitor contemporâneo $^{59}$ realiza, aproveitando-se a condição de poder navegar pelas letras, entrar em contato com o tempo e espaço que o texto permite cujo gênero em circulação oferecia pelo relato, valoração de documento histórico e etnográfico ${ }^{60}$.

Qual é o lugar e o espaço do gênero épico no século XXI? E como ler um poema que não pertence nem ao cânone da literatura brasileira nem da portuguesa? Como justificar esse investimento público, o qual espera uma finalidade pública que ora se confunde com a vontade particular de inserir a perspectiva regionalista na literatura

homem passou e deixou alguma marca da sua vida e inteligência, aí está a história.” LE GOFF, Jacques. A História como ciência: o ofício de Historiador. In: História e Memória. Campinas: Editora da Unicamp, 1966. P. 105 a 107.

58 No prefácio de Apologia da História ou o Ofício do Historiador, de Marc Bloch, Jacques Le Goff reflete quanto à condição de "legitimidade”, do papel e do ofício historiador e seu objeto, “a civilização como objeto privilegiado do historiador e a disciplina histórica como testemunha e parte integrante da civilização" e cita as tentativas de história psicanalítica de Michel de Certeau, as quais "permanecem sem posteridade". BLOCH, Marc. Apologia da História ou o Ofício do Historiador. Rio de Janeiro: Jorge Zahar Editor, 2001. P.15 a 34.

59 “De tiempo somos. Somos sus pies e sus bocas. Los pies del tiempo caminan em nuestros pies. A la corta o a la larga ya se sabe, los vientos del tiempo borrarán las huellas. Travesía de la nada, pasos de nadie? Las bocas del tiempo cuentan el viaje." GALEANO, Eduardo. Bocas del Tiempo. Buenos Aires: SigloVeintiuno Editores S. A, 2010. P.1.

60 E parte dessa continuidade de investigação pode ser arrolada quando se observa que, na terceira parte de A Escrita da História, Certeau trata dos sistemas de sentido escrito e oral e explica, no capítulo V a noção de etnografia, a partir da oralidade e do espaço do outro, tomando, por exemplo, Jean de Léry, ao abordar, pelo itinerário dos viajantes, a escrita histórica e a oralidade etnológica. Para ele, "histórias de viagens e quadros etnográficos permanecem no campo da narração", como "alterações provocadas numa cultura pelo encontro com outra". 
nacional, até porque o que se conhecia do que mais tarde foi chamado de Brasil, é exatamente essa parte setentrional que olha para o outro lado do mundo.

Nesse sentido, a produção acadêmica não deve e não pode ser refém desse jogo de mercado, até porque, dada a sua imparcialidade e transparência, precisa colocar na roda da fortuna literária, possibilidades infinitas, saberes mínimos necessários, os quais entrem em circulação e promovam conhecimento, aprendizagem e formação de leitores.

Entendemos que a Academia precisa quebrar o mundo e romper seu isolamento e alcançar a fronteira da escola, da roda de leitura, dos grandes saraus, seja na periferia ou nos espaços literários, pois se observa que hoje somente um pequeno público tem a possibilidade de desfrute, diante de uma constatação de que metade da população brasileira não consome a cultura que necessita ${ }^{61}$, para ser perceber como cidadão em construção constante, da condição de cidadania reivindicada desse processo histórico de exclusão de muitos direitos.

E como justificar esse financiamento público, quando o objeto de estudo pretende ler, pensar e tecer um diálogo sobre a contemporaneidade, a partir de uma narrativa colonial em forma de poema, cuja poética luso-brasileira ${ }^{62}$, não encontra 61 Reportagem da Folha de São Paulo, de 23 de setembro de 2014, atesta que 42\% dos brasileiros não consomem cultura.

62 “Bento é igualmente perito na Poética e na História (Barbosa Machado, 1741); "Que não é grande o

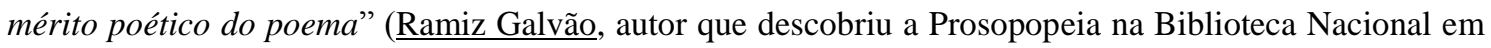
1873); "Não tem mérito algum de inspiração, poesia ou forma”. (José Veríssimo, 1912) “Início do nosso nativismo literário, sendo que os quatro últimos versos da estrofe 87 suficientes para fazer da Prosopopeia mais do que um canto bastardo camoniano" (Afrânio Peixoto, 1923) e "Sob o aspecto nativista, não passa de água meio morta com uns verdes e amarelos de cor local." Freyre, Gilberto. Acerca da Prosopopeia. Revista de História de Pernambuco. Recife, a.1, n.1, agosto de 1927; “o assunto é histórico e pernambucano, a forma, inclusive alguns versos, sensivelmente camoniana; o fundo mitológico, porém mais virgiliano do que camoniano".(Fernando de Oliveira, 1969); “Não tivesse o poema por si a marca de primeira "manifestação, em letra de fôrma, da literatura no Brasil e a suposta nacionalidade brasileira do autor, cuja incógnita biográfica desafiou a pesquisa por tanto tempo, e teria passado ao esquecimento sem grave prejuízo para o nosso patrimônio literário."(Galante de

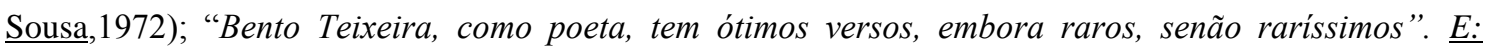
“Bento Teixeira não era, com certeza, um grande poeta, nem ocorre apresentá-lo como; tudo o que se 
respaldo no cânone literário ${ }^{63}$ por muito críticos $^{64}$, é desconhecida por muitos leitores, não faz parte da grade curricular das letras, senão sob a condição de optativa.

O que entusiasma a investigação de um gênero, sob essa finalidade pública de fomento se, para muitos editores, colocar à disposição do leitor, o texto épico, para ser culturalmente apreendido, é ainda um "produto não consumível" pelo grande público, um poema desconhecido, menor para alguns críticos, isolado pelo cânone literário e ainda, segregado pelo acesso, para leitores contemporâneos pela sofisticação da leitura advinda da fortuna vocabular e do gênero textual em questão.

Para quem pesquisamos ou escrevemos quando temos diante de nós um público que consome leitura pronta como se fosse um sanduíche fast food? ${ }^{65} \mathrm{E}$ como enfrentar essas barreiras de entendimento, compreensão e transposição de saberes se temos diante de nós grande parte da população que mal consegue entender um texto de jornal, por ausência de formação e de informação?

pretende é situá-lo como no lugar a que tem direito, histórica e literalmente ele vale pelo que significa”. (Wilson Martins, 1978). VILAR, Gilberto. Notas. In: O Primeiro Brasileiro. Onde se conta a história de Bento Teixeira, cristão novo, instruído, desbocado e livre, primeiro poeta do Brasil, perseguido pela Inquisição. São Paulo: Marco Zero, 1995. P. 262.

63 “Em meio à penúria literária que caracteriza nosso primeiro século, decerto a Prosopopeia ganha relevo e não pode passar despercebida, e por questões de precedência histórica, deve ser lembrada. No entanto, se o intuito desta coletânea fosse apresentar apenas o melhor de nossa literatura, obviamente não teria cabida o poemeto de Bento Teixeira". MOISÉS, Massaud. A Literatura Brasileira Através dos Textos. São Paulo: Cultrix, 2010. P. 39.

64 “Durante cerca de um século depois da atividade poética de Anchieta, quase não houve no Brasil a produção de escritos onde predominasse a imaginação poética ou ficcional, excetuando-se coisas tão insignificantes como o primeiro poema épico escrito em português, a Prosopopeia (1601), de Bento Teixeira (155?-1600), que só tem o mérito de precedência."CANDIDO, Antonio. Iniciação à Literatura Brasileira. Rio de Janeiro. Ouro sobre Azul, 2004. P.22.

65 Observamos inclusive que hoje as maiores livrarias no Brasil precisam adequar seu espaço físico a esse e leitor que precisa reconhecer entre os livros, o espaço da lanchonete, da diversão ou do lazer. As livrarias brasileiras promoveram, aos poucos, a inserção desse leitor consumidor, que nem sempre está lá para ler ou procurar um livro, participar de um debate ou conferência. 
Em tempos atuais, soa anacrônico para esses leitores, cada vez mais reféns de um mundo editorial, o qual produz e vende em massa letras como se fossem “commodities", cambiando e justificando o investimento pela grande negociação e barganha de autores, ao mesmo tempo em que escolhe o que se ler e para quem se vende, como podemos observar hoje que muitos espaços literários de inclusão, gestão e debate de ideias, na verdade, usam da fachada de "literário" e se transformaram num mercado sofisticado, para servir e divertir o público que sabe ler e pode pagar pelo livro a ser consumido. A Flip em Paraty e as Bienais do Livro pelo Brasil, sobretudo a de São Paulo, estão aí para provar esse fato: atendem a vontade e recepcionam o desejo do grande leitor consumidor que apenas circula pelos espaços e que nem mesmo consegue perceber que o evento homenageia um autor.

Há uma finalidade pública que deve e precisa ser justificada, até porque estamos pensando a leitura como o direito de aprender, de usufruir e de adquirir conhecimento, como um Direito Social que se coloca na qualidade de função arrolada pelo ordenamento jurídico, constitucional e amparado por legislação internacional, uma vez que o Brasil é signatário de muitas Convenções.

Diante desses pressupostos, a pesquisa investiga o plano da estética literária de um poema épico, ao mesmo tempo em que percorre, posteriormente, uma possibilidade leitura e análise da crônica descritiva realizada por Henry Koster, traduzida por Câmara Cascudo, por meio de articulações interdisciplinares, como ferramenta de recepção, no sentido de facilitar ao leitor a percepção, o resgate quanto à importância do conhecimento de um texto colonial, a aprendizagem de um rol de vernáculos clássicos, bem como o estudo de temas circulantes à concepção de mundo, como estratégia de se propor o diálogo entre séculos, culturas e questões, vigentes, amparado por vozes de outros escritores brasileiros que realizaram percepção comparada, contributiva.

Ainda, a investigação caminha no sentido de que essas narrativas promovam a observação de que o pêndulo transita entre o mundo literário e o histórico e que essa fronteira híbrida precisa comunicar com outras áreas, sobretudo com a antropologia, a geografia e a educação, para que se promova, pela função social de mediação de leitura, a possibilidade de se capacitar esse leitor a ler e a perceber pela narrativa, o processo literário histórico. 
Finalmente, a tese se coloca no sentido de se trazer a proposta de análise e reflexão de um poema épico para o campo da literatura brasileira que, nas suas bases, não apenas herdou um modelo camoniano de concepção, mas que se insere num universo estético de produção literária circulante e comunicante entre os mundos lidos, navegados e conquistados. 


\section{EMBARQUE}

\section{1. Entre poéticas e imagens}

"O intérprete do puro sentimento da terra." 66

Preliminarmente, pretendemos revisitar a estrutura realizada em Prosopopeia, de Bento Teixeira, com base no repertório cultural circulante, como fonte poética necessária ao diálogo literário com outros campos interdisciplinares, observando-se o gênero épico, como produção textual vigente no seu tempo.

Sob o ponto de vista estético, verificamos que o poema de Bento Teixeira continua a dividir parte da crítica, a qual lê Prosopopeia como uma quase obra-prima enquanto que para outra, o Poema não chega sequer a ser relevante.

Eneida Beraldi nos informa que Bento Teixeira fez história da memória, uma vez que Prosopopeia, escrito em homenagem ao capitão donatário Jorge de Albuquerque, configura-se como a primeira obra de um escritor laico a ser publicada no Brasil; no seu entender, Bento Teixeira é considerado o primeiro poeta das letras brasileiras e que sua mais rica produção não se encontra na Prosopopeia, porém na fortuna escrita realizada por Ele no silêncio do cárcere, como forma de se buscar a vida através da palavra ${ }^{67}$, por fragmentos escritos que a Inquisição guardou secretamente por séculos.

66 Almeida, Guilherme. Do Sentimento Nacionalista na Poesia Brasileira. São Paulo: Casa Garraux, 1926.

67 RIBEIRO, Eneida Beraldi. Bento Teixeira e a "Escola de Satanás". O Poeta que teve a "prisão por recreação, a solidão por companhia e a tristeza por prazer". Orientador: Anita Waingort Novinsky. São Paulo: USP, Tese de Doutorado, 2006. 
_Nesse sentido, Antonio Soares Amora pensa o "poemeto" como não merecedor de maiores considerações, além de ter sido feito, para muitos autores, como cópia remendada d'Os Lusíadas". ${ }^{68}$

“Bento é igualmente perito na poética e na história. "69

Por outro atalho, embarcamos na tradução de Luís da Câmara Cascudo para a viagem contada por Henry Koster, preservando-se a condição textual em que levantamos a cartografia em tela, com base na percepção de um modus de escrever adquirido por meio de vivências, leituras e de um corpus guardado, herança de todo um repertório imaginado, na condição de práticas e contatos recolhidos para uma narrativa em construção.

Aqui pensamos Koster como testemunha, não na condição de um mero passageiro que se desloca por terras nordestinas, sobretudo pernambucanas, mas como um colono que vivencia o espaço, fruto das relações humanas estabelecidas, para um repertório a ser guardado nas muitas gavetas, imaginárias ou não, como processo de escrita, entre o viajar e o escrever, sobretudo quando observamos que Ele, amigo do poeta Robert Southey, autor de uma História sobre o Brasil, a exemplo de Bento, era também um leitor escritor.

Robert Southey nos conta que o primeiro viajante a descobrir o Brasil foi Vicente Yañez Pinzón, o qual pertenceu à esquadra de Cristóvão Colombo, na primeira viagem realizada ao Novo Mundo. Na qualidade de comandante e mestre na Caravela Niña, Ele e Arias, seu sobrinho, obtiveram uma espécie de licença dada pela Coroa de

68 AMORA, Antônio Soares. A prosopopeia, de Bento Teixeira, à luz da moderna camonologia. Lisboa: Universidade de Lisboa, 1957.

69 VILAR, Gilberto. O Primeiro Brasileiro. Onde se conta a história de Bento Teixeira, cristão novo, instruído, desbocado e livre, primeiro poeta do Brasil, perseguido pela Inquisição. São Paulo: Marco Zero, 1995. 
Castela, para buscar novas terras e comércio, nos lugares não conhecidos ou explorados por Colombo.

The first person who discovered the coast of Brazil was Vicent Yañez Pinzon, who had sailed with Columbus, on his first voyage, as commander and master of the Niña. Seven years afterwards, he and his nephew Arias obtained a commission to go in search of new countries, and trade in any which Columbus had not previously appropriated. ${ }^{70}$

Entendemos que o conceito do primitivismo, base das vanguardas de início do século XX, a exemplo da estética percebida na poesia Pau Brasil, possa ser recuperado como ferramenta de percepção e interpretação para se pensar a condição de produção, circulação, categorização e recepção dessas obras, diálogos necessários entre nosso passado, nosso presente. ${ }^{71}$

Mencionamos aqui a contribuição de Benedito Nunes em cujo entendimento, Oswald de Andrade, no século XX "estava à procura das fontes emotivas, das origens concretas e metafísicas da arte":

[...] as vanguardas utilizaram para assinalar essa busca do elemento originário a que Oswald de Andrade se referia pelo primitivismo, em decorrência do choque que a sua descoberta produziu na cultura europeia, do "pensamento selvagem" (Claude Lévi-Strauss, 1962) pensamento poético, que participa da lógica do imaginário, e que é

70 SOUTHEY, Robert. History of Brazil. London: Hurst, Rees, Ormne and Brown, 1822. Vol.1. http://www.brasiliana.usp.br/handle/1918/01726710.

71 “A poesia Pau-Brasil é o ovo de Colombo - esse ovo, como dizia um inventor meu amigo, em que ninguém acreditava e acabou enriquecendo o genovez. Oswald de Andrade, numa viagem a Paris, do alto de um atelier da Place Clichy - umbigo do mundo - descobriu, deslumbrado, a sua própria terra. A volta à pátria confirmou, no encantamento das descobertas manuelinas, a revelação surpreendente de que o Brasil existia. Esse facto, de que alguns já desconfiavam, abriu seus olhos à visão radiosa de um mundo novo, inexplorado e mysterioso. Estava creada a poesia Pau- Brasil. Paulo Prado escreveu esse artigo intitulado Poesia Pau Brasil, em maio de 1924. In: Andrade, Oswald de. Pau Brasil, Edicção FacSímile. 
Observamos aqui a valorização dos estados brutos da alma coletiva, como fatos culturais, de natureza pictórica, contidos a saber: casebres, favela, carnaval, toda a história bandeirante e a comercial do Brasil, a formação étnica, a riqueza vegetal, o minério, a cozinha brasileira e, sobretudo a língua, pela "contribuição milionária de todos os erros" nos instrumentaliza a pensar a condição do espaço em que o poema brasileiro é composto, segundo um sistema épico português. (Ciacchi, 1993).

Pretendemos que o texto proponha uma leitura ${ }^{73}$ do poema épico como uma narrativa que transita entre gêneros textuais, uma espécie de máquina de ideias,

$72 \mathrm{Na}$ visão de Nunes, "em tais princípios de sua poética, na acepção ampla do termo, princípios que podem ser aplicados à pintura de Tarsila desse período, encerra o Manifesto, como aspetos complementares de uma só concepção primitivista, um programa de reeducação da sensibilidade e uma teoria da cultura brasileira.” E: “A perspectiva definida pelo Manifesto — sentimental, intelectual, irônica e ingênua ao mesmo tempo - é um modo de sentir e conceber a realidade, depurando e simplificando os fatos da cultura brasileira sobre que incide". Finalmente: "A inocência construtiva da forma com que essa poesia sintetiza os materiais da cultura brasileira equivale a uma educação da sensibilidade, que ensina o artista a ver com olhos livres os fatos que circunscrevem sua realidade cultural, e a valorizá-los poeticamente, sem excetuar aqueles populares e etnográficos, sobre os quais pesou a interdição das elites intelectuais, e que melhor exprimem a originalidade nativa. Nasce daí a teoria já crítica da cultura brasileira, focalizando a oposição, que foi um dos móveis da dialética do Modernismo, entre o seu arcabouço intelectual de origem europeia, que integrou a superestrutura da sociedade e se refletiu no idealismo doutoresco de sua camada ilustrada, e o amálgama de culturas primitivas, como a do índio e a do escravo negro, que teve por base". NUNES, Benedito. A Visão Poética Pau Brasil. Antropofagia ao Alcance de Todos. In: ANDRADE, Oswald. Do Pau-Brasil à Antropofagia e às Utopias. Editora Civilização Brasileira, 2a Edição. Obras Completas, V. 6, 1978.

73 "Diferentes orientações como a estética da recepção, a hermenêutica, as teorias semióticas do leitor ideal ou modelo, o chamado reader oriented criticism e a desconstrução elegeram como objeto de pesquisa não tanto os acontecimentos empíricos da leitura (objeto de uma sociologia da recepção, mas a função de construção - ou de desconstrução - do texto desenvolvida pelo ato de leitura, visto como condição eficiente e necessária da atuação mesma do texto como tal." E्: A assertiva subjacente a cada uma dessas tendências é: o funcionamento de um texto (mesmo não verbal) explica-se levando-se em consideração, além ou em lugar do momento gerativo, o papel desempenhado pelo destinatário na sua compreensão, atualização, interpretação, bem como o modo com que o próprio texto prevê essa 
composição de mundos e circulação de saberes, com enfoque naquilo que o texto nos conta, alcançando a narrativa descrita por Koster, não no sentido do cotejo, mas a título de ilustração de dois mundos poéticos diversos.

Desejamos alcançar uma possibilidade de traçar a percepção do olhar estrangeiro: de um português que compõe um poema épico sobre o Brasil e, mais tarde, de um inglês que, por experimentar cartograficamente o espaço, decompõe sua "história" sob o signo da viagem.

A memória é, de imediato, um documento histórico, uma fonte historiográfica que, configurando-se por um trabalho sensivel do que foi vivido, alcança uma inscrição literária suplementar. ${ }^{74}$

Almejamos com o presente estudo investigar como a escrita foi tecida, com base na observação do corpus lexical, no sentido de acompanhar a composição das formas de expressão, da nomeação lexical dos $\operatorname{mitos}^{75}$, das divindades e do espaço; ainda que imitassem o gênero textual em circulação, traduziam, pela épica ou pela viagem descritiva, uma condição de mundo que se colocava nos trópicos, ainda não descoberto pelos leitores.

participação." ECO, Umberto. Intentio Lectoris. Apontamentos sobre a Semiótica da Recepção. In: Os Limites da Interpretação. São Paulo: Editora Perspectiva, 2015 P.01, 02.

74 LIMA, Luiz Costa. As Formas Híbridas. Um termo elástico ou impreciso? História. Ficção. Literatura. São Paulo: Companhia das Letras, 2011. P. 353.

75 "O mito e a narração nunca estão completamente fora da história. $O$ ser e o existir pertencem a cada homem, mas encontram-se com as aventuras do humano de vir a ser no tempo. Se o Ulisses antigo é um signo que a civilização clássica interpreta e enche de significado no momento de seu apogeu, projetando a viagem profetizada por Tirésias nos confins do mundo conhecido, a aventura sem tempo do Ulisses medieval é ladeada obliquamente por sombras sugestivas que provêm da realidade." BOITANI, Piero. Naufrágio: Interpretação e Alteridade. In: A Sombra de Ulisses. São Paulo: Editora Perspectiva, 2005. P.29. 
Pesquisarmos e escrevermos sobre essas narrativas coloniais faz-se necessário, uma vez que parte da crítica, por um lado, pensa a Prosopopeia como leitura menor ${ }^{76} \mathrm{e}$, por outro, observa as Viagens ao Nordeste do Brasil na condição de fonte preferida como leitura pelos estudos historiográficos.

No entanto, observamos que a leitura de um canto épico, feita por um poeta que tentou escapar da Inquisição por meio da letra, propõe-nos a pensar para além do campo fonte, no sentido de se perceber como um inglês, na condição de testemunha descreve o processo de ocupação da terra e da gente do Brasil, arrolando grandezas percebidas por Câmara Cascudo, seu tradutor, como obras que nos convidam a pensar para além do mero documento: estamos diante de um gênero textual complexo, seja pela ação do imitar ou do escrever com base na memórias ${ }^{77}$ e vivências, o qual sugere uma possibilidade de interpretação para além da história, justificada por uma teia discursiva circulante em tempos de letras coloniais.

76 "Que não é grande o mérito poético do poema", (Ramiz Galvão, descobriu a Prosopopeia na Biblioteca Nacional em 1873); "Sob o aspecto nativista, não passa de água meio morta com uns verdes e amarelos de cor local (Freyre, Gilberto. Acerca da Prosopopeia. Revista de História de Pernambuco. Recife, a.1, n1, agosto de 1927); "O assunto é histórico e pernambucano, a forma, inclusive alguns versos, sensivelmente camoniana; o fundo mitológico, porém mais virgiliano do que camoniano". (Fernando de Oliveira 1969); "Não tivesse o poema por si a marca de primeira "manifestação, em letra de fôrma, da literatura no Brasil e a suposta nacionalidade brasileira do autor, cuja incógnita biográfica desafiou a pesquisa por tanto tempo, e teria passado ao esquecimento sem grave prejuízo para o nosso patrimônio literário". (Galante de Sousa, 1970); "O poema de Bento, nenhum valor literário apresenta, quanto ao conteúdo, mera sucessão de lisonjas bombásticas ao sublime Jorge, quer pela forma, canhestro decalque das diç̧ões camonianas". E: "Bento Teixeira, como poeta, tem ótimos versos, embora raros, senão raríssimos". Ainda: "Bento Teixeira não era, com certeza, um grande poeta, nem ocorre apresentá-lo como ; tudo o que se pretende é situá-lo como no lugar a que tem direito, histórica e literalmente Ele vale pelo que significa". (Wilson Martins 1978). VILAR, Gilberto. O Primeiro Brasileiro. Onde se conta a história de Bento Teixeira, cristão novo, instruído, desbocado e livre, primeiro poeta do Brasil, perseguido pela Inquisição. São Paulo: Marco Zero, 1995.

77 "A memória encerra o indivíduo na sua própria subjetividade, isola-o e suspende a situação dialógica [...]. A preponderância da memória de qualquer modo suscita um processo de subjetivação." ROSENFELD, Anatol. O Teatro Épico. São Paulo: Editora Perspectiva, 2004. P. 88. 
Requer a tese a busca por uma leitura atenta à escolha do corpus lexical no poema, bem como do vocábulo escrito e traduzido na narrativa, para acompanhar condicionantes histórico-geográficas enunciadas com base nas poéticas e nos discursos coloniais vigentes, como pressuposto de acompanhar, não de justificar a leitura dos textos, como necessária aos estudos de língua e de cultura brasileira, no sentido de se perceber as poéticas de pensamento em construção, como fomento de se refletir sobre processos, o que pode ser lido como literário e o que pode entendido meramente como histórico, por meio dos múltiplos diálogos textuais em debate.

Cabe aqui pensarmos nos processos de leitura dessas narrativas, meditando sobre a épica e a temática da viagem como gênero em circulação, propondo o diálogo com outros campos do conhecimento, para além da relação pendular entre a literatura e a história $^{78}$, como pressuposto de se pensar o campo narrativo como dialético quanto ao processo colonial de circulação de poéticas, privilegiando-se mais sua condição de linguagem do que documento, ao permitir que se estabeleça uma chave discursiva capaz de possibilitar a compreensão do processo literário pelo pensar: a estética textual como parte integrante do contexto dos escritos coloniais, muito além da condição de "poemeto" ou de "mera literatura de informação".

Analisamos esses antecedentes como indispensáveis para escritos posteriores, tarefa devida da presente tese, no sentido de se acompanhar valores presentes, como o histórico-literário, etnoliterário, graças ao gênero textual em circulação, como diários, tratados e viagens, prioritariamente lidos e pesquisados mais

78 "Os cronistas do primeiro século ainda presenciaram as cerimônias tupis dos habitantes da costa; Jean de Léry, Hans Staden e Fernão Cardim informem por todos." E ainda: Há expressões acentuadamente primitivas ou arcaicas, isto é, formas de cultura material e espiritual peculiares ao homem que sempre viveu sob o limiar da escrita. E há expressões de fronteira que se produzem pelo contacto da vida popular com os códigos letrados para cá trazidos ao longo de todo processo colonizador. Uma cerimônia de antropofagia entrevista por Hans Staden quando cativo dos tupinambás mão é, evidentemente, do mesmo estofo que a cena de uma guerra posta em um auto escrito em tupi por Anchieta e cantado e dançado pelos mesmos tupinambás, já expostos à catequese e, eventualmente, aprendizes do alfabeto latino. " BOSI, Alfredo. Sob o Limiar da Escrita. Colônia, Culto e Cultura. In: Dialética da Colonização. São Paulo: Companhia das Letras, 2002. P. 46 e 47. 
como "documento", menos como cartografia imaginada, restritos, portanto, a uma vocação interpretativa material de fonte, sem valor estético.

Nesse sentido, há que se pensar no papel que uma leitura intertextual e interdisciplinar justifica a condição e constatação de que estamos diante de um gênero híbrido $^{79}$, o qual não deve ser sequestrado pela crítica como menor, porque apenas informa ou documenta, uma vez que nos encontramos diante de um plano estético de leitura e interpretação das fontes e não sociológico.

A obra literária, mesmo a de valor estético menor, é forma em si e realidade histórica operada por uma consciência. Acreditar nesse fato significa trabalhar por um sistema de relações. ${ }^{80}$

Bento faz parte inequívoca da gênese artístico-histórica de Gregório de Matos, do Padre Vieira e outros letrados, das manifestações da cultura colonial, os quais o superam em engenho, arte e experiência.

Observarmos, sob o prisma da crítica literária, que fontes têm sido "ignoradas", como mero testemunho ou literatura de informação, discussão a qual iniciamos na defesa de mestrado em 2007, ao analisarmos a condição de circulação de crônicas, relatos ou diálogos, por parte dos estudos acadêmicos. Entendemos que não se

79 Sob a condição de analisar as expressões trânsito e trocas simbólicas, a Prof. ${ }^{a}$ Maria Luiza Scher Pereira, da UFJF, afirma que nos textos literários, as marcas do híbrido são deixadas pelo advento da experiência, seja ela vivida ou imaginada, da condição do deslocamento, motivado pela viagem, exílio, citação, tradução e, inclusive, "pelas formas diversas de leitura, desleitura e releitura, praticadas pelo escritor, para delas construir sua escrita por meio de empréstimos e apropriações culturais." PEREIRA, Maria Luiza Scher. Modos de viajar, modos de narrar. Modos de ler, modos de escrever. In: Literaturas em Movimento. Hibridismo cultural e exercício crítico. São Paulo: Coleção Via Atlântica, 2003. № 5P. 163-173.

80 ALVES, Luiz Roberto. A Fábula em busca da história. Relações entre as narrativas manuscritas de Bento Teixeira e o poema Prosopopéia. USP: Tese de Doutorado, 1997.

81 Idem. Confissão, Poesia e Inquisição. São Paulo: Editora Ática, 1983. 
pode generalizar a leitura do gênero crônica, como mero documento, mas que certas obras suscitam o debate para o campo híbrido denominado Literatura de Viagem.

Ainda, essas narrativas também levantam uma questão importante, de ordem filosófica, a saber: qual é o ponto em que a crítica se coloca, uma vez que temos diante de nós uma história contada ao passo que nos deparamos com uma narrativa a qual medeia processos de interpretação de um mundo coletado pela polifonia dos cronistas que, graças ao testemunho advindo da experiência do viajar, nos convidam ao embarque $^{82}$; na condição de aprendizes, experimentamos, pela leitura, o conhecimento de um mundo pluricentrado num rol de saberes, uma espécie de banquete cultural, o qual comporta aprendizagens por meio da experiência do contato, do conhecer o outro, do cantar sobre um mundo diverso e que precisa estar presente no banco da escola, com leitura de texto mediado e de contexto a ser compartilhado.

A pretensão da Tese estabelece um convite à leitura destes textos com base no presentismo proposto por Hartog ${ }^{83}$, no sentido de que há que se moldar o olhar para o embarque devido: esses escritos demandam a necessidade de pensar que estamos no

82 Como ponto de partida, podemos observar o testemunho dado por Hans Staden e perceber, como os escritores "se debruçaram sobre os documentos históricos que tinham à sua disposição, ou pelo menos sobre o que reconheciam como tal: crônicas, diários de viagem, cartas e documentos jesuítas. O cronista apresenta o Livro Segundo como "pequeno relatório verídico sobre a vida e costumes dos tupinambás dos quais fui prisioneiro", bem como o lugar "habitam a América; sua terra fica a $24^{\circ}$ de latitude sul, limitando com uma região que é chamada Rio de Janeiro". STADEN, Hans. Das armas de guerra dos selvagens. A Terra e Seus Habitantes. In: Duas Viagens ao Brasil. São Paulo: Edusp, 1988. P.178-179.

83 François Hartog nos propõe uma chave de interpretação, com base no reconhecimento da diversidade das culturas e de concepções levantadas por Claude Lévi-Strauss sobre Raça e História, publicadas pela UNESCO, em 1952 e mais tarde arroladas no Capítulo XVIII de Antropologia Cultural Dois. O Autor nos convida a pensar que o progresso se encontra em perspectiva "le progrès ensuite est fortemente mis en perspective", bem como observa a condição do tempo e da presença do outro, no processo de acumulação de condicionantes, diante da história em processo, no sentido de comunicar questões favoráveis a se perceber a construção de ideias em circulação. "Cést seulement de temps à autre que l'histoire est cumulative, c'est-à-dire, que les comptes s'additionnent pour former combination favorable." In: HARTOG, Francois. Régimes d"Historicité. Presentisme et Expériences du Temps. Paris: Éditions du Seuil, 2003. 
tempo de um Brasil Colônia cuja contemporaneidade guarda marcas profundas, como a práxis consuetudinária em detrimento do contrato.

Propor a leitura dessas narrativas, com base no Regime de Historicidade, uma reflexão de François Hartog, para uma compreensão melhor entre o passado e o futuro, com reflexos no tempo presente, é um ponto de partida a ser considerado, tanto para o processo de escrita da história, como para a percepção do campo da literatura em diálogo com a história, vez que pensamos a aquisição dos saberes conectados pela circunstância de circulação de grandezas. Inclusive, porque estamos diante de um gênero híbrido, o qual necessita de uma leitura mediada, dada a fortuna do vernáculo e, sobretudo, pelo fato de que não se pode realizar a leitura de narrativas coloniais somente com os olhos de um leitor atado ao tempo presente.

\section{Avec le régime d'historicité on touché ainsi à l'une des conditions de possibilité de la production d'histoires: selon les rapports respectifs du présent, du passé et du futur, certains types d'histoires sont possibles et d'autres non. ${ }^{84}$}

Nesse sentido, ainda, com a tese pretendemos perceber, graças à poética da narrativa, os discursos e os espaços coloniais arrolados pela genética textual em construção, não na condição de mero documento, mas como forma de expressão, graças à linguagem épica, poética e descritiva, às possibilidades de múltiplas leituras, bem como de interpretação que as narrativas permitem e não menos da contribuição do olhar de um leitor, o qual se encontra em processo de acúmulo e assimilação de saberes, na condição de sujeito dessa percepção.

Leitores, investigadores ou críticos, com base na leitura dessas fontes e por meio dos atalhos da interpretação, terão diante de si a possibilidade de abrir múltiplos caminhos, recuperar vozes e acompanhar como a apropriação cultural de saberes se faz, em virtude da produção literária em diálogo com as fontes em processo.

Nesse sentido, questões foram levantadas para se acompanhar a forma escrita, bem como o cânone representativo, a recepção desses diálogos pela crítica, no 
sentido de se pensar como posicionar tais narrativas sob o signo literário, na roda da fortuna das letras.

Optamos aqui pela estratégia de se estabelecer a análise e a reflexão das narrativas por meio de diálogos interdisciplinares como tentativa de percepção do contexto, das fontes e dos pressupostos como possibilidade de se interpretar e traduzir o texto para um leitor contemporâneo.

Nesse sentido, na qualidade de mediação desses saberes, propomos uma condição de leitura de fôlego, um olhar experimental, uma interpretação atenta que permita alcançar esses saberes submersos, seja pelo vernáculo ou pela longevidade textual, reduzindo-se a velocidade do pensamento e do olhar, mediante estratégia artesanal de decodificação para a devida interpretação do mundo cantado ou descrito, como tentativa de se tecer uma rota pelas letras cuja finalidade é ver esse mundo encoberto pela ausência do não ler um texto épico ou uma narrativa extensa.

Ao princípio de relativismo proposto por Lévi-Strauss, Hartog agrega uma segunda concepção, com base no lugar que o observador ocupa:

Afin de montrer que la dimension et la vitesse de déplacement des corps ne sont pas des valeurs absolues, mais des fonctions de la position de l'observateur, on rappelle que, pour um voyageur assis à la fenêtre d'un train, la vitesse et la longueur des autres trains varient selon que ceux-ci se déplacent dans la même sens ou dans un sens opposé. Or, tout membre d'une culture en est aussi étroitement solidaire que ce voyageur idéal l'est de son train. ${ }^{85}$

Hartog acompanhado por Lévi-Strauss, acrescenta a este princípio o lugar da posição do observador, nas bases elementares da teoria que relativiza o diálogo do encontro. A imagem aqui sugere um observador, o qual se desloca em viagem e vê um mundo diante de si, através da janela de um trem, o qual percorre não somente_espaços

85 LÉVI-STRAUSS, Claude. Race et histoire. Unesco, coll. " La question raciale devant la science moderne", 1952, repris dans Anthropologie structurale deux. Paris: Plon, 1973, p.377-431. 
físicos, paisagens refletidas pelos contornos do olhar, mas toda uma narrativa por recortes de imagens e sombras criadas, nos emaranhados caminhos do pensamento.

A circunstância de se compor o caminho por meio da viagem, da experiência ou da leitura de mundo auxilia-nos a compreender muitas questões, as quais a investigação acolhe, na tentativa de se perceberem as poéticas em circulação que dialogam com o presente, por meio da cultura legítima representativa da expressão de um povo.

A Poesia Pau Brasil é uma sala de jantar das gaiolas, um sujeito magro compondo uma valsa para a flauta e a Maricota lendo o jornal. No jornal anda todo o presente. ${ }^{86}$

Partindo-se da concepção do Embarque, a tese se propõe a estabelecer o debate acadêmico, sugerindo os seguintes capítulos: Paisagem, Mundos, a Prosopopeia da Viagem por Letras Coloniais, Ler um Mundo de Saberes e, finalmente, no Desembarque, sem deixar de passar pelo carnaval, ao resgatar da nossa memória, as muitas vivências guardadas entre as gavetas dos afetos e das letras. Boa viagem...

86 O Manifesto Antropofágico, lançado por Oswald de Andrade, no Correio da Manhã, em março de 1924. In: TELES, Gilberto Mendonça. Vanguarda Europeia e Modernismo Brasileiro: apresentação e crítica dos principais manifestos vanguardistas. 16.ed.Petrópolis, Editora Vozes, 2000. 
O Zé Pereira chegou de caravela E preguntou pro guarani da mata virgem - Sois cristão? - Não. Sou bravo, sou forte, sou filho da Morte Teterê Tetê Quizá Quizá Quecê!! Lá longe a onça resmungava Uu! ua! uu!

O negro zonzo saído da fornalha Tomou a palavra e respondeu - Sim pela graça de Deus Canhém Babá Canhém Babá Cum Cum! E fizeram o Carnaval. ${ }^{87}$

Das muitas viagens realizadas ao Nordeste do Brasil, entre 2007 e 2014, com o intuito de se descobrir e experimentar lugares somente conhecidos pela leitura das crônicas como fontes de pesquisa, Pernambuco é, sem sombra de dúvida, o lugar de onde retornamos, a cada carnaval vivenciado nas ladeiras de Olinda, com muitas memórias guardadas na bagagem, de onde o olhar retorna modificado, cada vez mais sofisticado pela experiência dos afetos, dos sabores ${ }^{88}$ e dos sons.

87 Andrade, Oswald. Tupi or not Tupi. This is the question. http://www.releituras.com.

88 “Receita de Munguzá de engenho: Toma-se o milho para munguzá inteiro, sem os olhos (esse milho encontra-se no comércio. Antigamente é que era preciso tirar os olhos do milho em casa) e deixa-se em água fria durante a noite. No dia seguinte lava-se e vai ao fogo para cozinhar em água. Quando o milho está tenro põem-se leite de coco, sal e açúcar. Deixa-se ferver um pouco. O leite de coco poderá ser substituído por leite de vaca". FREYRE, Gilberto. Açúcar. Uma Sociologia do Doce, com Receitas de Bolos e Doces do Nordeste do Brasil. São Paulo, Global, 2012. P. 127. 
Moro em São Paulo, mas namoro Olinda ${ }^{89}$.

Dos sucessivos carnavais passados entre Olinda e Recife, a experiência de seguir bonecos gigantes ${ }^{90}$, maracatus ${ }^{91}$, caboclinhos $^{92}$, troças $^{93}$, bandas de frevo ${ }^{94}$, o

89 Frase dita por Alceu Valença: "namoro Olinda e moro no Rio de Janeiro !"

90 "Feitos para encantarem pela leveza e graça com que flutuam nos ares, acima das cabeças dos foliões, nas tardes luminosas de Carnaval. Suas roupas coloridas são de pano humilde, do mesmo algodão barato, que veste os corpinhos minchos dos meninos nordestinos." BONALD NETO, Olímpio. Os Gigantes foliões em Pernambuco: Olinda: Edição Fundação Centro de Preservação dos Sítios Históricos de Olinda, 1992, p. 93.

91 Maracatu-nação hoje designa uma manifestação da cultura pernambucana, especificamente da região do Recife e de Olinda, que é encontrada principalmente no período carnavalesco, quando desfilam pelas ruas da cidade em um cortejo real acompanhado de uma orquestra percussiva." E ainda: "Para os Maracatus é imprescindível uma identidade no sentido de que sejam criados ou mantidos os sentimentos de pertencimento dos seus membros, internamente de suas comunidades, de modo que as pessoas se sintam partícipes de forma plena, e não apenas nos momentos carnavalescos." LIMA, Ivaldo Marciano de França. Maracatus do Recife: novas considerações sob o olhar dos tempos. Recife: Edições Bagaço, 2012. P. 47 e 52.

92 Segundo Bonald Neto, "De ascendência indígena, desfilam com seus cocares com penas coloridas, porta-estandarte mirins, apitos, pífanos e flautim de taquara, tarê e preaca, ritmando a dança. Originalmente teria sido um auto de inspiração sagrada". BONALD NETO, Olímpio. Os Gigantes Foliões em Pernambuco. 2.ed. Recife: Companhia Editora de Pernambuco, 2007.

93 Olinda $n^{\circ}$ 2, do Clube Carnavalesco Misto Elefante de Olinda, composto por Clídio Nigro e Clóvis Pereira, é considerado o Hino de Olinda:. "Ao som dos clarins de Momo / O povo aclama com todo ardor / O Elefante exaltando a suas tradições / E também seu esplendor / Olinda esse meu canto / Foi inspirado em teu louvor / Entre confetes e serpentinas / Venho te oferecer / Com alegria o meu amor / Olinda! Quero cantar a ti esta canção / Teus coqueirais, o teu sol, o teu mar / Faz vibrar meu coração, de amor a sonhar / Em Olinda sem igual / Salve o teu Carnaval!"

94 "Pernambuco tem uma dança que nenhuma terra tem", versos que iniciam o frevo-canção "É Frevo, Meu Bem", de Capiba. "Diferente da grande maioria dos gêneros da música popular brasileira, o frevo tem origem em um único estado: Pernambuco.” TELES, José. Do Frevo ao Manguebeat. São Paulo: Editora 34, 2012. 
samba do Patusco ${ }^{95}$, a ciranda de Lia $^{96}$, a sambada de coco ${ }^{97}$, o coco de umbigada e o cavalo-marinho, entre outros brinquedos, Olinda nos proporciona a experiência da transviagem cultural, por meio da aprendizagem de um repertório de saberes de uma Terra sem-fim ${ }^{98}$, fruto de toda uma circulação de mundo: etnias ameríndias, povos e nações africanas, costumes e práticas lusitanas de uma contribuição colonial, como falares, quitutes, danças e religiosidade, nossa herança, patrimônio imaterial, legítimo de nossa formação.

O Brasil devia eleger da sua herança colonial - isto sim - uma série de valores em harmonia com a paisagem tropical e com as condições brasileiras de vida. ${ }^{99}$

95 Grêmio Recreativo Escola de Samba Patusco comanda o som dos tamborins nas ladeiras do Sítio Histórico de Olinda.

96 Maria Madalena Correia do Nascimento, Lia de Itamaracá, é considerada a mais famosa cirandeira do Brasil". "Ciranda é uma dança de roda de mãos dadas, o vai e vem no balanço do bombo e da zabumba, todos iguais democraticamente entram e saem da roda quando querem." OLIVEIRA, Leonidas Henrique de. Ciranda Pernambucana uma dança e uma música Popular. Recife: Monografia apresentada ao curso de Especialização em cultura Pernambucana, 2007.

97 Os Mestres e brincantes definem a sambada como festa, a reunião, o encontro, o espaço para cantar, dançar, tocar, celebrar, sambada é o espaço para brincar, sambar o coco.” BASTOS, Dani. Coco de Umbigada. Cultura Popular como Ferramenta de Transformação Social. Recife: Editora Daniela Bastos dos Santos, 2011.

98 Um dia eu hei de morar nas terras do Sem-fim. BOPP, Raul. Cobra Norato. São Paulo, José Olympio Editora, 2001.

99 "Independente do modernismo do Rio e de São Paulo, houve um movimento também de revolução cultural - e não apenas literária - na mais velha região do Brasil: no Nordeste. Igualmente exprimiu uma revolta contra o estreito colonialismo, dominante nos meios intelectuais e artísticos, ainda que não repudiasse a experiência brasileira nem a integração dos valores europeus e extraeuropeus durante a época colonial no conjunto da cultura brasileira em formação. E: "Proclamava a necessidade de atitudes e valores extraeuropeus, sem deixar de reconhecer a necessidade que tinha o Brasil de intimo contato com a Europa e com o seu próprio passado Europeu”. [...] "Dai a importância que deram alguns líderes do movimento à cozinha tradicional, à confeitaria e à arquitetura tradicionais, aos móveis antigos e à arte popular - não para preservá-los como coisas sagradas sob a forma de relíquias para 
Assim, na circunstância de turista aprendiz, a exemplo de Mario de Andrade, trazemos, na bagagem, a experiência vivenciada pelo contato com o outro na percepção da paisagem, ao experimentarmos uma espécie de munguzá cultural que nos ajuda a compreender que, a escolha de continuar a reflexão e pesquisa sobre narrativas poéticas do Brasil Colônia, legitima nossa opção de investigação acadêmica sobre outros palcos do descobrimento. Faltava incluir Pernambuco, buscar as devidas peças de um quebra-cabeça que nos une.

Como proposta de percepção acadêmica pelas teias da literatura como viagem, a partir de leituras realizadas de outros viajantes como Gandavo, Gabriel Soares, Jean de Lery e Claude D'Abeville, perseguimos a trilha modernista que nos instigou a pensar sobre a terra brasilis e suas gentes, segundo suas fontes e tesouros máximos, deixando de lado o olhar pronto pelo academicismo e crítica, para saborear como leituras necessárias e contínuas, uma viagem pelas letras, partindo-se da leitura de um poema épico, a Prosopopeia ${ }^{100}$, até alcançarmos as Viagens ao Nordeste do Brasil, por meio da tradução de Luís da Câmara Cascudo.

A leitura das crônicas, diários, poemas, diálogos, descrições, histórias e tratados e a proposta de se caminhar pelas ladeiras, entre casarões coloridos, nos Quatro Cantos, Alto da Sé, Guadalupe, Carmo e Varadouro, nos possibilita a pensar sobre nossa ancestralidade afro-indígena, sobre a terra e as gentes do Brasil, por meio de um repertório apreendido, como caldo cultural de saberes que, devidamente, precisa estar presente na sala de aula, nos espaços do aprender sobre cultura brasileira, por meio das práticas e aprendizagens que os muitos brinquedos carnavalescos nos possibilitam degustar.

Pensar o ponto em que estamos, entre ler textos e ver o mundo, perceber o espaço por onde muitas vozes circularam, por entre janelas, vidraças e terraços que

utilizá-los como bons motivos ou sugestões, no desenvolvimento de uma arte e de uma maneira de viver realmente brasileiras". FREYRE, Gilberto. Interpretação do Brasil. São Paulo, Global, 2015. P.199, 200.

100 “O século XVI é o fundamento indispensável para os estudos e compreensão das origens da formação da Literatura Brasileira." Produção Intelectual do Período Colonial - I. O Século XVI - As Fundações. In: CASTELLO, José Aderaldo. A Literatura Brasileira. Origens e Unidade. Volume1. São Paulo: EDUSP, 1999. 
olham-nos devagar ${ }^{101}$, saber que aqueles caminhos de pedra guardam segredos, que os muitos túneis escondem um passado de fuga de escravos e de cristãos novos, experimentar a trajetória por ruelas e rios que desembocam em igrejas seculares, não na condição de turista aprendiz, agora como viajante que experimenta o aprender por meio de uma viagem lida e imaginada, primeiro, ao redor do quarto ${ }^{102}$,para um universo único, permite-nos cuidar de um olhar menos geográfico e mais imaginado, não teorizado pelo contexto histórico, mas observado pelo hipertexto que se tece aos poucos, graças às rodas conversas, como função comunicativa de se buscar esse outro de que somos parte, uma dialética que nos transporta a um tempo e espaço únicos na cosmogonia épico-descritiva de um Pernambuco que poeticamente nos convida a dialogar com nossa questão de brasilidade.

Há, pois uma necessidade enunciativa que nos faz pensar sobre a prosopopeia da descoberta, pela tradução da viagem que, culturalmente, nos propõe Câmara Cascudo, convidando-nos a revisitar esse mundo de saberes que Koster arrolou a seu modo, por sua conta e risco.

Nesse sentido, foi preciso buscar por ti, Olinda ${ }^{103}$, nossas primeiras letras, cidade onde moramos nos quatro, cinco dias de folia e por onde percorremos ladeiras e caminhos feitos de pedras e de letras, entre a ficção do poeta e o testemunho do viajante.

101 Pensamos aqui no poema Cidadezinha Qualquer. ANDRADE, Carlos Drummond de. Alguma Poesia. Rio de Janeiro: Record, 2007.

102 MAISTRE, Xavier. Viagem ao Redor do Meu Quarto. Porto Alegre: Mercado Aberto, 1998.

103 “Olinda, dada a sua posição de metrópole brasileira do primeiro século e que dela saíram os primeiros livros de nossa literatura, tenha sido ele "o lugar em que primeiro abrolhou a flor literária em nossa pátria", como assim nos informa Capistrano de Abreu. Vanildo Bezerra Cavalcanti. "Olinda e sua Formação Literária.” Revista do Arquivo Público. Recife, 31-32 [33-34]:3-152, 1977-1978), p. 65. 


\section{PAISAGEM: entre a tela e a escrita}

“O Brasil é uma paisagem" 104

Bento Teixeira, no Prólogo ${ }^{105}$ de Prosopopeia, estabelece a quem dirige o poema: ao Capitão e Governador da Capitania de Pernambuco, Jorge D’Albuquerque Coelho, inserindo no cenário épico a Nova Lusitânia, nome como assim Olinda era conhecida.

\section{PRÓLOGO 106}

Dirigido a Jorge d'Albuquerque Coelho, Capitão e Governador da Capitania de Paranambuco, das partes do Brasil da Nova Lusitânia,

etc.

104 “Ah, o Brasil não é uma pátria, não é uma nação, não é um povo, mas uma paisagem." Nélson Rodrigues. Recepcionamos aqui a percepção apresentada no Artigo, reafirmando a importância das diferentes linguagens em circulação na pesquisa acadêmica que a tese acolhe, na linha dos estudos culturais, ao concordar que "os desenhos rodrigueanos ressignificam o imaginário, por meio do ficcional, misturando sujeitos, cores e imaginários, elementos fomentadores de uma identidade nacional polimórfica e reacendida a cada dia na pena e na ideia dos diversos autores que compõem a nossa história, seja literária, seja factual”. BRIGLIA, Tcharly Magalhães. Desenhos de Brasil na Crônica de Nelson Rodrigues. In : Revista Urutágua - acadêmica multidisciplinar do DCS /UEM, n³1, Nov 2014 abril de 2015 , ISSN1519-6178 file:///C:/Users/Lucineia/Documents/Leon2015/23957-114253-2-PB.pdf Acesso em 14 de fevereiro de 2016.

105 "Prólogo é toda parte da tragédia que antecede a entrada do coro". ARISTÓTELES. Poética. In: A Poética Clássica. Introdução de Roberto de Oliveira Brandão. Tradução de Jaime Bruna. São Paulo: Editora Cultrix, 2011. P.31.

106 TEIXEIRA, Ivan. Multiclássicos Épicos. Prosopopeia. O Uraguai. Caramuru. Vila Rica. A Confederação dos Tamoios. I-Juca-Pirama. São Paulo: Edusp. Imprensa Oficial, 2008. 
Arrolam-se musas, ninfas, deuses, divindades, sereias uma pintura clássica moldada pelas letras, segundo a concepção de Horácio. ${ }^{107}$

Se é verdade o que diz Horácio que Poetas e Pintores estão no mesmo predicamento

Tétis, que em ser fermosa se recrea,

Traz das Ninfas o coro brando e doce:

Clímene, Efire, Ópis, Panopea,

Com Béroe, Talia, Cimodoce;

Drimo, Xanto, Licórias, Deiopea, Aretusa, Cidipe, Filodoce,

Com Eristea, Espio, Semideas,

Após as quais, cantando, vem Sereas.

Isso no sentido de que escrever também funciona como uma possibilidade de se criarem imagens ${ }^{108}$, sobretudo, de uma terra vista a partir de um universo da memória,

107 "Sabemos, desde Aristóteles, que os diferentes gêneros de poesia, a despeito de serem todos certo tipo de imitação ou mimese, se distinguem um do outro. A epopeia e a poesia trágica, assim como a comédia e a poesia ditirâmbica, e também a maior parte da aulética e da citarística, são todas em geral imitações. Diferem, porém, entre si, por três coisas: ou por imitar com meios diversos, ou coisas diversas, ou por fazê-lo diversamente e não da mesma maneira. Há diversos tipos ou gêneros de poesia, ou porque os meios, ou os objetos e modos de imitar Aristóteles efetivamente se refere? Resumindo os três primeiros capítulos de Poética, digamos que os meios de imitação são o ritmo, a linguagem e harmonia; os objetos, as ações de homens melhores, ou piores, ou iguais à média; os modos, a narração a representação ou ambas". NOGUEIRA, Érico. A Lírica Laudatória no Livro Quarto das Odes de Horácio. São Paulo: USP, Dissertação de Mestrado, 2006. 
de todo um repertório, fortuna de um processo de leitura clássica e experiência escolástica, como professor, tradutor, escritor por espaços olindenses.

E vós, sublime Jorge, em quem se esmalta

A Estirpe d'Albuquerques excelente,

E cujo eco da fama corre e salta

Do Cauro Glacial à Zona ardente,

Suspendei por agora a mente alta

Dos casos vários da Olindesa gente,

E vereis vosso irmão e vós supremo

No valor abater Querino e Remo.

A construção poética parte pela estética do criar segundo o desenho, a imagem, a representação clássica; primeiro, o rascunho $e$, por conseguinte, a busca pela perfeição entre a métrica e a rima.

Prólogo

[...]; e estes pera pintarem perfeitamente uma Imagem, primeiro na lisa távoa fazem riscunho, pera depois irem pintando os membros dela extensamente, até realçarem as tintas, e ela ficar na fineza de sua perfeição; [...]

\footnotetext{
108 Pensamos aqui nas formas interdiscursivas do imaginário estético e cultural, relações centrais entre literatura e arte, no sentido de se pensarem os eixos de formação tanto da sociedade quanto dos espaços de circulação e ocupação inseridos nos contextos. A narrativa imagética, para além de documentar, compõe cenários ao interpretar relações sociais e espaciais, entre os falares de uma mesma língua, entre as relações de poder e entre o campo e a cidade. FARIAS, Sônia Lúcia Ramalho de e LEITE, João Denys Araújo (Org.) Imagens do Brasil na Literatura. Recife: UFPE, 2005.
} 
Na condição de vassalo, apura o ofício do escrever com engenho e arte pela epopeia $^{109}$, colocando-se como servo digno de beijar as mãos de seu Senhor:

[...] Assim eu, querendo debuxar com obstardo pincel de meu engenho a viva imagem da vida e feitos memoráveis de vossa mercê, quis primeiro fazer este rascunho, para depois, sendo-me concedido por vossa mercê, ir mui particularmente pintando os membros desta imagem, se não me faltar a tinta do favor de vossa mercê, a quem peço, humildemente, receba minhas rimas, por serem as primícias com que tento servi-lo.

Nesse sentido, pensar a poética épica ${ }^{110}$ realizada por Bento Teixeira parte de uma concepção de composição pela arte, a tela e o pincel em busca da rima, lapidada, em construção.

No entanto, como pensar no elo de criação estabelecido por este diálogo entre o ofício do escrever e o do pintar quando se tem em mãos um poema cuja estética

\begin{abstract}
109 "Na perspectiva do século XVI e XVII, essa circunstância de "pessoa"- fundamental na retórica greco-latina, mas inexistente como elemento de invenção na poética aristotélica, subsumida que está entre ação, caráter e pensamento, passa a ser determinante. Tais lugares de pessoa que compõem os personagens, a epopeia em prosa busca-os na retórica." E: " É na epopeia em prosa o lugar onde as ações, costumes e sentenças se efetuam". Ainda: "Desde que a epopeia em prosa trata preferencialmente de personagens, e desde que esses personagens fornecem elementos qualificadores de seu caráter e de suas ações discursando, a invenção de tais personagens reúne a uma só vez o topói personarum que, na retórica, concernem a demonstração de um discurso e concernem além disso ao orador". Finalmente: "São personagens permanecentes de quem, por um lado, o poeta e, por outro, eles mesmos exemplarmente - universalmente, como corresponde à verossimilhança da poesia - que praticam ações virtuosas (ou infames) e que tem tal ou qual caráter". MUHANA, Adma Fadul. A Epopeia em Prosa Seiscentista: uma definição de Gênero. São Paulo: FFLCH - USP, Tese de Doutorado. 1996. P. 79.
\end{abstract}

110 "Uma epopeia não pode ser escrita em oposição índole de sua época: o profeta e o satírico podem-se manter alheios ao seu tempo, ou opor-se a ele, mas o autor épico tem de dar voz aos sentimentos gerais. Embora Camões seja indiscutivelmente poeta, é lido pelo leitor de hoje como se fosse prosador. Os Lusíadas tem mais valor que um romance histórico: eles nos dão o tom do pensamento da época. Sob este aspecto, são poesia épica”. POUND, Ezra. A Arte da Poesia. São Paulo: Cultrix, 1988. P. 143. 
se comunica com a imitação da arte produzida no seu tempo? E ainda, como adequar a lente do olhar para essa poética?

Cantem poetas o poder romano

Submetendo nações ao jugo duro;

O Mantuano pinte o Rei Troiano,

Descendo à confusão do reino escuro;

Que eu canto um Albuquerque soberano,

Da fé, da cara pátria firme muro,

Cujo valor e ser, que o céu lhe inspira,

Pode estacar a lácia e grega lira.

Como realizar essa tentativa de decodificação de significado uma vez que o mundo visto por aqui parte de um processo de criação escrita segundo a concepção de estética clássica $^{111}$ de Horácio $^{112}$ e alcança a contemporaneidade de um leitor que precisa dar conta de uma leitura cujo léxico é sofisticado, tanto do ponto de vista do vocabulário como pela escolha da mitologia?

111 "Desde Aristóteles até os estruturalistas, passando por Jakobson, enfim, fazendo uma recapitulação ainda que sumária da história da estética, sempre encontramos uma preocupação central de definir o estético ou o artístico ou o literário como uma tarefa de representação que se apoia em mediações”. BOSI, Alfredo. Entre a Literatura e a História. São Paulo: Editora 34, 2013. P.221-222.

112 “As ações ou se representam em cena ou se narram”. E: "Princípio e fonte da arte de escrever é o bom senso". Ainda: “Quem aprendeu seus deveres para com a pátria e para com os amigos, com que devemos amar o pai, o irmão, o hóspede, qual a obrigação de um senador, qual a dum juiz, qual o papel do general mandado a guerra, esse sabe com segurança dar a cada personagem a conveniente caracterização”. HORÁCIO. Arte Poética. In: A Poética Clássica. Introdução de Roberto de Oliveira Brandão. Tradução de Jaime Bruna. São Paulo: Editora Cultrix, 2011. P.31. 
Poesia é como pintura ${ }^{113}$ : uma te cativa mais, se te deténs mais perto; outra, se te pões mais longe; esta prefere a penumbra; aquela

quererá ser contemplada em plena luz, porque não teme o olhar penetrante do crítico; essa agradou uma vez; essa outra, dez vezes repetida, agradará sempre. ${ }^{114}$

Num instante de pausa e reflexão, ao caminharmos pelas ruas da cidade, entre pensamentos e leituras realizadas, alcançamos uma possibilidade feliz de visitar a exposição de Iberê Camargo, no Centro Cultural Banco do Brasil, ${ }^{115}$ em abril de 2014, momento em que foi possível perceber seu processo de criação ${ }^{116}$.

113 "A relação entre a poesia e a pintura, até agora, tinha sido abordada de modo muito superficial; até Platão não encontramos nenhum autor cujo foco teórico fosse a analogia entre essas duas artes, muito menos encontramos autor que coloque essa relação como imagem dos fundamentos do conhecimento e como crítica social tão devastadora." E: "Um poema ou uma pintura não são objetos reais, não tem relação autêntica com a verdade. Pintura e poesia são imitações de uma aparência e é vã qualquer tentativa de relacioná-las diretamente com a verdade. Conclui-se assim que o poeta e o pintor tecnicamente nada mais são do que fabricantes de imagens, e não fabricantes de objetos, os outros artífices". RABELLO, Felipe Simas; TELES, Gilberto Mendonça. UT pictura poesis: um panorama histórico das relações entre poesia e pintura. Rio de Janeiro: 2014. Tese de doutorado - Departamento de Letras - Pontifícia Universidade Católica do Rio de Janeiro.

114 HORACIO. Idem, P.65.

115 Iberê Camargo: um trágico nos trópicos, de 03 de maio a 07 de julho de 2014, em São Paulo, uma parceria do CCBB e da Fundação Iberê Camargo, sob a curadoria de Luiz Camillo Osório, a mostra abordou a questão do homem, seu corpo e sua existência. 2014 é o ano de centenário de Iberê Camargo. http://culturabancodobrasil.com.br/portal/ibere-camargo-um-tragico-nos-tropicos/. Acesso em 01 de julho de 2015.

116 "O historiador é como o pintor de estilo: o quadro (isto é, o período), o assunto (isto é, aquilo que ele vai escolher do período) são-lhe dados mais pelos acasos da vida do que pelo trabalho do espírito. Mas estes não dizem nada de sua arte, que é o verdadeiro segredo da profissão e que não consiste em imaginar relações entre várias espécies de fatos reputados até independentes ou em pôr questões novas sobre fatos que já são conhecidos: não, o historiador deve sobretudo devolver à existência, pela magia da sua narrativa, todas estas vidas, estes pensamentos, estas paixões, perdidos nos manuscritos antigos que ninguém antes dele releu." FURET, François. A Oficina da História. Trad. Felipe Jarro. Lisboa, Gradiva, sd. P. 21. MICELI, Paulo. Para o Mar dos Viajantes. In: O Ponto onde Estamos. Campinas: Editora UNICAMP, 2008, p. 21. 
E uma indagação se coloca: como pensar o processo de criação de Iberê Camargo e de Bento Teixeira diante do hiato secular entre processos de criação? Observamos um pintor que cria sua obra pela desconstrução enquanto que o outro segue a 'imitatio’ vigente. Como pensar universos tão díspares?

Além de pintar, Iberê Camargo escreveu e nas suas memórias nos lembra sobre a fortuna dos nossos guardados, convidando-nos a não olhar para a tela com os olhos prontos da crítica, a pensar para além dos "rabiscos" e "borrões". Ele nos ensina a não embarcar com o olhar pronto, práxis devida de todo pesquisador. Ele nos convoca a instigar, pelo modo de concepção da pintura e uso dos carretéis, nossas próprias escolhas, a partir do momento em que abrimos nossas gavetas e recolhemos nossas memórias e por que não nossas leituras?

A condição aqui se coloca da seguinte forma: Iberê cria suas telas a partir de um processo de deformação, desconstrução de estruturas terminadas, rompendo com a imagem já definida. Iberê nunca se filiou a correntes ou movimentos. ${ }^{117}$

Bento, por outro lado, parte da imitação estética do escrever, ao criar uma alegoria de composição com base no molde visto; por isso, a crítica decidiu por pensá-lo como um poeta menor, uma vez que mantinha o mesmo paradigma camoniano do criar e não do romper. ${ }^{118}$

117 Iberê Camargo é um dos grandes nomes da arte brasileira do século 20, com obra extensa: pinturas, desenhos, guaches e gravuras. Nasceu em Restinga Seca, interior do Rio Grande do Sul, Brasil, em 1914 e iniciou seus estudos na Escola de Artes e Ofícios de Santa Maria. Em 1948 viajou para a Europa, através de um Prêmio de Viagem ao Estrangeiro para aprimoramento técnico, oportunidade em que visitou museus, realizou cópias dos grandes mestres da pintura e estudou gravura e pintura. Conquistou inúmeros prêmios: Bienal de São Paulo, Bienal de Arte Hispano-Americana em Madri, Bienal de Veneza, Bienal de Gravuras em Tóquio, entre outros. No final dos anos 1950, o artista desenvolveu um dos temas mais recorrentes em sua pintura: os carretéis, brinquedos de sua infância que o levaram, mais tarde, à abstração, e que estiveram presentes em sua obra até a fase final. Ao longo de toda sua produção, nunca se filiou a correntes ou movimentos. http://www.iberecamargo.org.br/site/o-artista/ibere-camargo.aspx. Acesso em 05 de julho de 2016.

118 "Bento Teixeira compõe um poema extremamente menos engenhoso e artístico que o de seu auctor, Camões, publica Prosopopeia em 1601, 37 anos depois de todos os decretos do Concílio de Trento terem 
Bento foi um poeta que transitou entre mundos lidos e vividos e também fez suas escolhas. Era "polemista", "livre pensador", segundo Luiz Roberto Alves e "intelectual rebelde", segundo Kênia M. A. Pereira, no tempo em que a Inquisição vigiava a tudo e a todos. Ser um professor não eclesiástico no século XVI, diante de uma "cultura amordaçada e cerceada" pela censura inquisitorial, segundo Maria Luiza Tucci Carneiro $^{119}$, não era uma tarefa fácil, sobretudo para um poeta articulado a uma diversidade de questões.

Essas considerações nos levam a pensar sobre o lugar da crítica, diante de como ler Prosopopeia com os olhos no presente quando, na verdade, temos que buscar outra forma de concepção enquanto leitores, observadores das condicionantes desses mundos, no sentido de não reproduzir a fala pronta de parte dos estudos literários, a qual promove uma leitura do poema como menor. ${ }^{120}$

sido declarados leis do reino de Portugal pelo rei D. Sebastião. Sabendo que imitar é fazer semelhante, moraliza a verossimilhança catolicamente, pois ela depende da verdade inquisitorial. E, seguindo seu auctor, usa dos deuses antigos como metáforas fabulosas que ilustram virtudes católicas. HANSEN, João Adolfo. Introdução: Notas sobre o Gênero Épico. In: Teixeira, Ivan. Multiclássicos Épicos. São Paulo: EDUSP, 2008.

119 “Cristóvão Colombo havia sido financiado pela Coroa de Castela e, em decorrência disso, o território descoberto passou a pertencer àquele reino. A princípio Castela, no esforço de assegurar a posse da América apenas para seus naturais, promulgou uma legislação que lhe garantia exclusividade no tocante à soberania nas novas terras. Assim, no Novo Mundo, seria considerado estrangeiro todo aquele que não fosse nascido em solo de Castela, fosse ou não súdito do mesmo rei”. E: "Em 1580 os Portugueses tornaram-se vassalos do rei espanhol, fato que em nada alterou sua situação com respeito à América hispânica, onde continuavam a ser legalmente excluídos". CARNEIRO, Maria Luíza Tucci. O antisemitismo nas Américas: memória e história. São Paulo: Edusp, 2007.

120 “A Prosopopeia é um poemeto épico, [...] no qual a imitação, as reminiscências, imagens e talvez os versos d'Os Lusíadas de Camões constituem como que a intimidade mesma da obra. A crítica nacional não tem sido benigna com o autor". José Veríssimo (História da Literatura Brasileira, 1916) é mesmo duro: chama-lhe o 'patriarcha dos nossos' e 'engrossadores literários'; Ronald de Carvalho (Pequena História da Literatura Brasileira, 1922) é também severo: 'poema de mediocre feitio, não se lhe percebe um grande sopro de inspiração, nem ao menos qualquer relevo de estylo; frequentes indecisões de expressão, muita mesquinhez de estro e de linguagem e raras partes de boa poesia'. PEIXOTO, Afranio (Prefácio). Bento, Teixeira. Prosopopea. Publicações da Academia Brasileira. Clássico Brasileiros. I Literatura. Rio de Janeiro: Álvaro Pinto, Editor, 1923. 
Aqui os processos de criação não se comunicam, porém provocam-nos a pensar quanto à condição de recepção: como compreender a tela e como ler o poema afastando rótulos e escolhas: importante pensar como público e leitores promovem essa desconstrução quanto ao olhar de concepções diversas de linguagem e de arte e como nós nos relacionamos com essas rupturas, seja pela imagem, seja pelo léxico vernacular e mítico.

Como sugestão, propomos realizar o percurso da leitura e análise da poética de Prosopopeia, sob a estética do refazer uma interpretação que buscasse um diálogo com outras fontes ${ }^{121}$, pressupostos que a crítica literária até então não havia percorrido, no sentido de borrar a tela já concebida sobre a Prosopopeia, como circunstância de se encontrar com quais outras vozes sua estética podia manter condições dialógicas.

Ao observar o processo de uma tela em construção por meio de um documentário, bem como perceber as bases de sua formação e das muitas rupturas estéticas realizadas pelo autor, levantamos, a partir da observação de seu repertório, uma possibilidade de se pensar a leitura e o estudo de Prosopopeia, sob a condição de disponibilidade acadêmica; em outras palavras, como a crítica recepciona o poema, como autores brasileiros dialogam com o texto, bem como pensar nas condições de mundo e de contemporaneidade entre texto, contex to e recepção.

Como fundamento, observamos que Iberê nos brinda com o convite de pensar que:

a memória é a gaveta dos guardados. Minha bagagem são os meus sonhos; todo criador é um Pedro Álvares Cabral. [...] Escrever pode ser, ou é a necessidade de tocar a realidade que é a única segurança

121 "Interessante lembrarmos aqui o filósofo francês Derrida, que concebe a intertextualidade como um “tecido" formado à base de fios tomados emprestados de outros textos. Este processo parece ser o percorrido pelo autor da Prosopopeia, uma vez, que tal obra é tecida com fios emprestados não só d'Os Lusíadas, como também de episódios do Naufrágio da nau Santo Antônio, da Eneida e das Metamorfoses”. PEREIRA, Kênia Maria de Almeida. Educação e Literatura: o Professor e o Poeta Bento Teixeira entre a Heresia e a Censura. Uberlândia: UNITRI, 2008. 
de nosso estar no mundo - o coexistir. É difícil, se não é possível, precisar quando as coisas começam dentro de nós. ${ }^{122}$

Diante dessa reflexão, sob o signo da concepção estética de composição do retrato como o lugar da memória, percorremos a leitura de Prosopopeia, não nos esquecendo de abrir a gaveta dos muitos guardados lidos, sob a condição de analisá-la mediante a práxis de criação do artista, para percebermos léxico e contexto, paisagem e espaços cartograficamente criados.

Nesse sentido, Prosopopeia há que ser lida para além da forma, observandose os pressupostos de criação de Bento Teixeira, intelectual numa terra de poucos letrados, conhecedor de universos culturais diversos, colônia e metrópole, práticas religiosas distintas e que, segundo um modelo clássico de produção, foi “o primeiro autor a elaborar um poema épico no Brasil colonial" ${ }^{123}$.

O prazer de se decodificar um tempo histórico funciona como uma possibilidade de tradução da forma e da expressão vigentes, a título de comunicar o conteúdo para um leitor contemporâneo, graças a uma estratégia de leitura cujo parâmetro se propõe a pensar a partir das ruínas, dos escombros da produção textual em circulação, porque estamos a observar um evento ocorrido do outro lado do Atlântico, descrito à moda peninsular, sobre personagens transportados para os trópicos e que pertenciam à outra paisagem.

122 Escrito em Porto Alegre, entre 1993 e 1994, as frases anotadas foram coletadas na Exposição do CCBB, São Paulo, 2014 e pertencem à Gaveta dos Guardados, livro de memórias escritas por Iberê Camargo. Publicado em conjunto pela Fundação e pela editora Cosac Naif, lançado em maio de 2009, foi organizado por Augusto Massi, o qual nos conta que: "o conjunto de contos é uma viagem no tempo de "um homem que ainda está a caminho", como Iberê mesmo procurou se autodefinir. A obra é considerada um precioso esboço biográfico, que, mais do que ajudar a compreender o artista, desdobra o homem, envolto ao tema da tragédia”.

123 "No que tange o universo da intertextualidade, Bento Teixeira busca como fonte de inspiração, para criar seu texto, o vate português; Camões, não plagiando ou copiando servilmente, pois Prosopopeia tem enredo e desenvolvimento próprios." PEREIRA, Kênia Maria de Almeida. Educação e Literatura: o Professor e o Poeta Bento Teixeira entre a Heresia e a Censura. Uberlândia: UNITRI, 2008. 
Ao propormos um atalho entre as letras coloniais e a tela contemporânea, guardamos, em primeiro lugar, as vozes críticas, os rótulos prontos sobre movimentos literários ou concepção estética de estilos; num segundo plano, buscamos interpretar épica e arte segundo o engenho de seus autores, respeitando-se individualidades necessárias, como tempo e espaço: o quadro à espera do artista, a letra como criação do poeta.

Ao vivenciarmos a composição do quadro de Iberê Camargo por meio de um vídeo, momento em que foi possível sacudir as ideias e levantar novas questões, no sentido de acompanhar seu processo de criação artística, descobrimos que não havia lugar para o academicismo somente pela forma, mas por meio da expressão, dos sentimentos, bem como a necessidade de comunicação e diálogo com as cores, com o movimento dos pincéis e a percepção do pintor no instante de criação.

Ao observarmos o processo de composição da tela por meio de um documentário, na condição de uma narrativa em processo, constatamos como as bases de sua formação se colocam diante das rupturas estéticas necessárias realizadas pelo autor, como seus guardados precisavam sair das muitas gavetas da memória, dando vida aos carretéis que, guardiões de experiências, promovem a poética da expressão. ${ }^{124}$

Nesse sentido, passamos a pensar sobre a obra como texto em processo, tanto pela dialética da criação quanto pela recepção, ao acompanharmos seu processo de elaboração: como ele, artista, processa seu método, ao "formar" e "deformar" imagens, alternando tons, cores e riscos.

Perante nossos olhos podemos perceber, com entusiasmo, seu processo de criação e expressão: o inconsciente que contribui para o retrato e que nos instiga a pensar, como leitores, o quanto cada obra de arte e de escrita demanda-nos o exercício do pensar, do desacelerar diante de uma tela, a qual provoca-nos interpretações e sensações diversas, ou no plano de leitura de uma épica seiscentista; há que se perceber

124 Para Augusto Massi, em Gaveta dos Guardados, dois princípios parecem balizar a criação e o destino pessoal do pintor, ao entender que "a vida é uma caminhada" e que ao compor o quadro, realiza uma espécie de metáfora da viagem: "antes de iniciar a viagem - o quadro -consulto minha bússola interior e traço o rumo." Carretéis da Memória. In: CAMARGO, Iberê. Gaveta dos Guardados. São Paulo: EDUSP, 1998. P.14. 
o sentido do poema por meio de muitas práticas do ler e do reler versos. Prosopopeia não é um texto para ser lido de um só fôlego, pois demanda ao leitor um exercício de práticas de leitura e de percepção de camadas de sentidos.

Somos aqui convidados a refletir sobre um mundo coletado pela polifonia, por meio do embarque, de outros diálogos que o texto-obra nos convoca a realizar, ao mesmo tempo em que, partícipes do processo, aprendizes de plantão, interpretamos linhas, por cores ou versos, distanciados do tempo presente, uma vez que freamos o passo, já entramos na galeria ou abrimos um livro. Somos assim transportados para esse mundo, uma viagem pelas letras ou pelos contornos de uma imagem.

A partir da observação de todo um repertório subjetivo, levantamos a possibilidade de se pensar estética e produção de um quadro; por que não pensar na condição do retrato épico que uma narrativa como a Prosopopeia nos proporciona.

Ao estilo da sua escrita, com base no gênero textual em circulação de seu tempo, permitiu-se ao poeta emprestar seus sentimentos, dando vida a seres, elementos, lugares por ele arrolados a seu modo, sob sua pena e papel, a exemplo dos pincéis e da tela do pintor.

Pensamos, nesse sentido, observar como Bento compõe sua poética dando forma ao texto, convidando-nos a tirar das nossas gavetas outras experiências lidas, como Os Lusíadas, de Camões ou a Odisseia de Homero e compor nossa reflexão e entendimento, por meio de um diálogo promovido por um leitor que hoje, ao ler uma narrativa $^{125}$ ou ao observar uma tela, caminha entre o experimentar e o pensar, a exemplo da experiência dos pincéis livres, comunicando, tanto na viagem do ler como na do pintar, guardados e mundos por meio da recepção.

125 "O livro é uma máquina de nos fazer levantar a cabeça”, frase dita pelo escritor português Gonçalo M. Tavares no encontro Minha Língua, Minha Pátria, realizado em São Paulo, em 2015, na Livraria Cultura. E ainda: "E é isso que a literatura permite, que a nossa cabeça funcione sozinha nesse momento em que a levantamos. O livro é uma máquina de nos fazer levantar a cabeça e não olhar para nada. 99\% das obras artísticas nasceram deste momento em que a pessoa suspende a cabeça”, quando nela se associam imagens, ideias". In: http://www.publico.pt/culturaipsilon/noticia/o-livro-e-uma-maquina-denos-fazer-levantar-a-cabeca-1692173 Acesso em 30 de janeiro de 2016. 
Sob o signo da concepção estética de composição do retrato, o lugar da memória, da proposta de se traçar o caminho, retomamos a leitura de Prosopopeia, não nos esquecendo de abrir a gaveta de muitos guardados lidos, sob a condição de analisála mediante a práxis de criação do artista, para perceber a proposta do sentido, de como o léxico dá conta do mundo tecido, de como a paisagem se compõe pela escrita, de como as rimas funcionam na condição de cor e textura estética de uma narrativa que, mais do que propor colorir os feitos históricos de uma família influente, promove uma voz de autodefesa, ao tentar se esconder da Inquisição como também denúncia que lhe foi feita.

Ao embarcarmos na viagem escrita por Iberê ${ }^{126}$, pelo seu "andarilhar de pintor", aqui narrado na condição de um diário de vivências, quão relevante é a percepção do compor estético quando a tinta não mais se coloca na tela, mas agora nas folhas; a mão que escreve com o mesmo engenho que pinta, de forma autobiográfica e que nos convida a abrir nossas próprias gavetas de memórias.

Pensar o teor de Prosopopeia é peregrinar pelas letras, por uma pesquisa que pretende evitar o taylorismo curricular como industrialização acadêmica, mas observar a riqueza estética que se coloca pela concatenação sequencial das formas, de como contar os proveitos e os insucessos de uma viagem que inclui a capitania de D. Duarte no diálogo d'além mar.

Assim, a Prosopopeia não deve ser lida como um poema épico que apenas documenta um tempo histórico, que imita um gênero textual camoniano, um poemeto com forma luso-brasílica; porém, como uma épica que seguia os moldes de produção textuais vigentes à época.

Segundo Kênia Maria de Almeida Pereira, Bento Teixeira, ao compor sua obra, não ridiculariza o modelo, nem parafraseia Camões, Homero ou Virgílio, uma vez que a

\footnotetext{
126 “A memória é a gaveta dos guardados. Nós somos o que somos, não o que virtualmente seríamos capazes de ser. Minha bagagem são os meus sonhos. Fui o poeta das ruas, das vielas silenciosas do Rio, antes que se tornasse uma cidade assolada pela violência. Sempre fui ligado à terra, ao meu pátio. Gaveta dos Guardados In: CAMARGO, Iberê. Gaveta dos Guardados. São Paulo: EDUSP, 1998. P.31.
} 
temática do poema é outra, ao manter o gênero epopeia com "criatividade" e "inovação":

Evidentemente, vários momentos da Prosopopeia nos remetem automaticamente ao texto camoniano, em um constante diálogo intertextual, próprio do Renascimento, em que eleger um grande poeta para tornar-se guia e mentor dos escritores principiantes era artifício comum e encorajado. ${ }^{127}$

A proposta aqui é realizar a provocação quanto à recepção desse gênero, que se coloca sob a luz de seu tempo, o desafio de se traduzir o léxico e o sentido para o leitor contemporâneo, conversar sobre a alteridade, a interdisciplinaridade e a transdisciplinaridade das questões, sobretudo estéticas, no sentido de se obter uma das muitas chaves de interpretação, mediante o embarque num mundo composto por versos, imagens e tons.

Alternativamente, há também a intenção de se promover uma leitura e reflexão sob a prática de articulação com o presente, compreendendo-se as condições do ocupar a terra, transpor gentes, domesticar a paisagem e de circularem práticas clássicas de observação de rima, lírica e versificação poética em construção.

Essas condições servem de pressupostos, meio para se alcançar a finalidade maior: o resgate de um texto sequestrado pela crítica, como leitura necessária. Afinal, como nos lembra Horácio "os pintores e os poetas sempre gozaram da mesma forma do poder de ousarem o que quisessem".

127 PEREIRA, Kênia Maria de Almeida. Educação e Literatura: o Professor e o Poeta Bento Teixeira entre a Heresia e a Censura. Uberlândia, UNITRI, 2008. 


\title{
IV. MUNDOS
}

\section{IV.1. Épico}

\begin{abstract}
Writers of belles-lettres. That is, men who didn't really invent anything, but who specialized in some particular part of writing, who couldn't be considered as 'great men' or as authors who were trying to give a complete presentation of life, or of their epoch.
\end{abstract}

Ezra Pound ${ }^{128}$

Bento Teixeira ${ }^{129}$, autor de Prosopopeia, professor e intelectual para a Colônia, ${ }^{130},{ }^{131}$ herege ${ }^{132}$ e cristão-novo para a Coroa Portuguesa, foi perseguido pela

128 POUND, Ezra. Compass, Sextant, or Landmarks. In: ABC of Reading. London Faber and Faber, 1991.

129 "O jovem poeta Bento Teixeira se impôs como um representante de seu tempo: cristão-novo, professor, comerciante, advogado, polemista, até mesmo assassino da esposa e pretenso livre-pensador do final do nosso primeiro século". ALVES, Luiz Roberto. Introdução. In: Confissão, Poesia e Inquisição. Ensaios. São Paulo: Editora Ática, 1983. P.04.

130 "Bento Teixeira foi um dos primeiros professores e intelectuais rebeldes que viveu no Brasil colonial. Foi um dos primeiros professores não eclesiásticos a ministrar aulas de latim, matemática, filosofia." PEREIRA, Kênia Maria de Almeida. O Poeta e o Professor Bento Teixeira: Transgressão e Censura no Brasil do Século XVI. Uberlândia: Centro Universitário do Triângulo.

131 "Depois de casado, foi a Olinda onde estabeleceu escola de ler, escrever e latinidade, ensinando mais de sessenta moços em dois anos, instruindo na doutrina cristã e nos bons costumes e tendo procedimento exemplar”. ALVES, Luiz Roberto. O Trajeto em Três Dimensões. In: op. cit. P.41.

132 "A autobiografia de Bento Teixeira, que principia por elementos mensuráveis, conteúdos de sua vida desde o nascimento no Porto - condição primeira da verdade - , e termina por novos fatos que se podem detectar, ganha, porém, toda a sua força nas aberturas do mundo para além da sala abafada do 
Inquisição, preso e torturado, vindo a falecer em 1600, em Lisboa, de tuberculose ${ }^{133}$, sem ver sua obra editada ${ }^{134}$.

Escreve, Prosopopeia ${ }^{135}$, com arte e engenho, poema digno do gênero textual vigente à sua época e seu tempo. Como leitor e educador, comunica sua defesa por escrito, por meio da estética quanto à forma (epopeia) e expressão (linguagem mítica, proveito, exemplo e invenção) ${ }^{136}$ vigentes, personificando as virtudes de um

interrogatório.” E: “Ele mesmo, feito personagem nas equações anteriores caminha por toda a "costa do Brasil" e mostra as crenças e os erros, ora envolvido no pecado, ora justaposto a um diálogo levantando problemas na base do argumentandi gratia, a exemplo de Proteu, que na Prosopopeia exerce semelhante papel em concluir com o narrador. Em toda a confissão, a sensação transmitida é a de presença, daquele que viu e participou, e jamais que escutou alguém dizer. Aqui, uma oposição básica à atitude do ouvir, aceita pelo Santo Ofício e por certo uma representação capaz de extrapolar inclusive as exigências feitas". ALVES, Luiz Roberto. Confissão e Ficção. In: op. cit. P.103-110.

133 “As últimas informações que fecham a sua biografia, sua trajetória, sua vida, constam do início do Processo [5206] na ordem em que estava guardado na Torre do Tombo. A primeira é um certificado passado pelo médico João Álvares Pinheiro, no qual consta - estamos em 9 de abril de 1600 - ter visitado Bento Teixeira "na cadeia da Corte da cidade de Lisboa e que estava "em cama”, com febre, tendo lançado algum sangue pela boca segundo pude julgar de um pano que se mostrou e assim me pareceu doente e ter necessidade de se curar". Não se cura. Na capa do documento, lado direito superior, encontramos: "É falecido Bento Teixeira e faleceu andando com a penitência, em fim de julho de 1600. A tuberculose, ou doença semelhante, é a resposta final à sua discutida e discursiva existência". ALVES, Luiz Roberto. Fábula em busca da História: relações entre as narrativas manuscritas de Bento Teixeira e o poema Prosopopeia. São Paulo: USP, Dissertação de Mestrado, 1977.p.119, 120.

134 “Bento não tinha mais do que 23 anos de idade. Para alguns críticos, apenas 19. Era o seu sonho, que ele queria ainda continuar e aperfeiçoar. A morte não deixou." VILAR, Gilberto. O Primeiro Brasileiro. Onde-se conta a história de Bento Teixeira, cristão-novo, instruído, desbocado e livre, primeiro poeta do Brasil, perseguido e preso pela Inquisição. São Paulo: Marco Zero, 1995. P. 262.

135 "O ano de 1593 foi de muitas tribulações para o poeta, sendo provavelmente o mesmo da morte de Felipa Raposa. Segundo Capistrano de Abreu, também foi nesse tempo que Bento Teixeira compôs o poema Prosopopeia.” ALVES, Luiz Roberto. O Trajeto em três Dimensões (com a palavra o povo, os inquisidores e o réu) In: op. cit. P. 65.

136 “O mito não é literatura, é a reinterpretação dos mitos que se torna literária, reinterpretação que atribui aos mitos uma polissemia que só pode ser compreendida no quadro de uma sociedade que tem uma relação determinável com a história e o arquivamento de certas mensagens sociais sacralizadas, 
"herói”, digno de cantar os feitos de um soberano, metáfora de um mundo colonial imaginado a partir dos trópicos, entre os mares e o exílio, prisioneiro de consciência, entre as muitas fugas e o claustro, silenciado pela Inquisição .

Bento Teixeira divide o Poema em sete ${ }^{137}$ partes, mediante as seguintes estrofes:

Proposição: I

Invocação: II a VI

Narração: VII a XVI

Descrição do Recife de Pernambuco: XVII a XXI

Canto de Proteu: XXII a XCII

Fala de Netuno: XCIII

Epílogo: XCIV

legitimadas no mais alto grau cultural como sendo distintas de qualquer outra mensagem". MARTINON, Jean-Pierre. O Mito da Literatura. In: Atualidade do Mito. São Paulo, Livraria Duas Cidades, 1977. P. 123.

137 Sete é um número perfeito e exclusivo no universo: os quatro elementos da Terra com os três da Trindade Santa. Sete em língua hebraica é o mesmo que jurar. Como bom leitor das fontes medievais e da cabala, Bento conhecia que sete, na arte gótica em forma de pomba, eram os dons do Espírito Santo (Sabedoria, Entendimento, Conselho, Força, Ciência, Piedade e Temor a Deus); sete eram as virtudes (Fé, Esperança, Caridade, Prudência, Justiça, Força e Temperança); sete eram as artes nas ciências (Lógica, Gramática, Retórica, Aritmética, Música, Geometria e Astronomia); sete eram os sacramentos (Batismo, Confirmação, Eucaristia, Penitência, Unção dos Enfermos, Ordem e Matrimônio); sete eram também os pecados capitais (Soberba, Ira, Inveja, Luxúria, Gula, Avareza e Preguiça); sete eram os pedidos no pai nosso, (três ao Céu e quatro a terra); sete as obras de misericórdia (dar de comer, beber e vestir, dar pousada, assistir aos enfermos, visitar os presos e cuidar dos que partem pela morte); sete são os braços $\underline{\text { do }}$ candelabro judeu, com sete braços indicando os sete dias da criação. No casamento judaico, sete são as voltas. http://numerologiadacabala.blogspot.com.br/2011/06/o-misticismo-do-numero-7.html. Acesso: 12 de maio de 2016. 
Nos estudos já realizados sobre o poeta, Eneida Beraldi Ribeiro informa-nos que Bento Teixeira foi preso por possuir e ler livros proibidos, traduzir a Bíblia para a linguagem vernácula, proferir "impropérios" à Virgem, desacreditar dos dogmas católicos, negar-se a colaborar com a Igreja e não trabalhar aos sábados:

em Pernambuco, onde foi preso, Bento Teixeira redigiu seu primeiro texto. Nele, nega qualquer tipo de culpa, salientando que era homem cristão e, como mestre de moços, ensinava os bons princípios da religião aos seus alunos. Nos cárceres em Lisboa, continuou a escrever, ainda negando qualquer tipo de apostasia. Em fins de 1597, muda seu discurso e conta que tinha sido judeu até então, mas que arrependido pedia perdão e reconciliação com a igreja. Bento

Teixeira descreve encontros, conversas, desentendimentos pessoais, dúvidas sobre religião e política. Tece uma rede de relacionamentos e parentescos dos habitantes do Brasil, com os quais convivera, alguns falsos em textos que Luiz Roberto Alves, em sua tese sobre o poeta, denominou de teatrais. Bento Teixeira se fez personagem e através de sua oralidade mudou uma série de dados do passado, misturando fatos reais com imaginários, recriando um discurso adaptado às condições em que se encontrava ${ }^{138}$.

Bento Teixeira, segundo Andrea Ciacchi, chegou à Colônia com poucos anos de idade. Filho de cristãos-novos em fuga do Santo Ofício português, respondeu denúncia por prática de judaísmo ao Visitador Inquisitorial em 1593. Ao ser preso e transferido para Lisboa, conheceu a solidão e a penitência durante o exílio, ao ser submetido a longo processo, o qual culminou com sua "plena confissão":

homem com uma formação pública jesuítica e uma educação doméstica judaica, com atitudes de livre pensador, polemista, tradutor de textos hebraicos e preceptor dos filhos de grandes latifundiários pernambucanos. ${ }^{\mathbf{1 3 9}}$

138 RIBEIRO, Eneida Beraldi. Bento Teixeira e a Escola de Satanás. O Poeta que teve a prisão por recreação, a solidão por companhia e a tristeza por prazer. Orientador: Anita Waingort Novinsky. São Paulo: USP, Tese de Doutorado, 2006;

139 CIACCHI, Andrea. A Prosopopeia de Bento Teixeira: Materiais e Apontamentos para uma Revisão Historiográfica. João Pessoa: UFPB, 1997. 
Escreve Prosopopeia ${ }^{140}$, um longo poema de noventa e quatro estrofes ${ }^{141} \mathrm{em}$ decassílabos heróicos, sob o argumento de narrar os feitos históricos da família de Jorge de Albuquerque Coelho, donatários da capitania de Pernambuco, com base na guerra promovida contra os índios da costa do Brasil e pela participação épica na batalha de Alcácer-Quibir, instante histórico em que se funda o mito de Dom Sebastião ${ }^{142}$.

Mais do que cantar a história das virtudes de Albuquerque Coelho, Bento Teixeira ${ }^{143}$ produz uma obra esteticamente digna de arte poética, relacionando feitos

140 “Impressa pela primeira vez em 1601, a Prosopopeia de Bento Teixeira é não apenas exemplo do gênero prosopopéico, em que divindades olímpicas se nos apresentam como partícipes das peripécias por que passa o herói, Jorge de Albuquerque Coelho, mas também exemplo de dialogismo, já que aí se empresta voz, entre outros, a Proteu para que, por seu intermédio, se teça a fantasia do canto ao referido herói." MOREIRA, Marcello. Louvor e História em Prosopopeia. In: Multiclássicos. Épicos. Ivan Teixeira (org.) São Paulo: EDUSP / Imprensa Oficial, 2008.

141 “A Prosopopeia é um poemeto em decassílabo heroico, oitava rima, com 94 estrofes. Eis, em linhas gerais, o seu plano: Proposição (est.1.); Invocação (est.2-6); Narração (est.7-16); Descrição do Recife de Paranambuco (est. 17-21); Canto de Proteu (est.22-92); Fala de Netuno (est.93); Epílogo (est.94)." SOUSA, J. Galante. A Prosopopeia. In: Em Tôrno do Poeta Bento Teixeira. São Paulo: IEB, 1972. P.2130 .

142 “Outro episódio narrado no poema é a travessia do oceano por Jorge de Albuquerque Coelho com destino a Portugal, durante a qual o herói teve de refrear seus companheiros de infortunada viagem que quase se entregaram à antropofagia". MOREIRA, Marcello. Louvor e História em Prosopopeia.

143 "Vale dizer que Bento Teixeira, por ter sido o primeiro, não foi o único escritor dessa época, no Brasil, a ter livros impressos. Capistrano de Abreu faz duas observações que merecem ser levadas em conta: Primeiro, tanto Jorge de Albuquerque quanto o seu irmão mais velho Duarte II tinham “tendências literárias” e “ambos escreveram livros”. Segundo, “foi Pernambuco, nem podia deixar de sê-lo, o centro de que partiu nossa evolução literária; para compreendê-la, o historiador de nossa literatura deve ali estudar-lhe os germens. Antes do grupo baiano geralmente conhecido, existiu o grupo literário pernambucano, em que figurou Frei Francisco do Rosário, Jorge de Albuquerque, o autor dos Diálogos, Bento Teixeira e outros. Donde se conclui que foi Pernambuco o lugar em que primeiro abrolhou a flor literária em nossa pátria. [In Anais da Biblioteca Nacional, v. XIII (1885), p. XII e XIII]”. VILAR, Gilberto. O Primeiro Brasileiro. Onde-se conta a história de Bento Teixeira, cristão-novo, instruído, desbocado e livre, primeiro poeta do Brasil, perseguido e preso pela Inquisição. São Paulo: Marco Zero, 1995.P. 262. 
históricos com personagens míticas, partindo da paisagem do Brasil que, nesse instante, é conhecida, a partir de Pernambuco ${ }^{144}$, entrelaçando diálogos e visões, como se lê nestes versos da estrofe XXV.

A fama dos antigos coa moderna

Fica perdendo o preço sublimado:

A façanha cruel, que a turva Lerna Espanta com estrondo d'arco armado:

O cão de três gargantas, que na eterna Confusão infernal está fechado, Não louve o braço de Hércules Tebano.

Pois procede Albuquerque soberano.

Proteu $^{145}$, por meio de uma narrativa épica, "prosopopéica”, constrói seu argumento com base na verossimilhança ${ }^{146}$, ao invocar inúmeras musas e divindades

144 A reflexão sobre letras coloniais parte de Pernambuco com base na fortuna histórica de um passado: "Por sua formação política, herdando a altivez dos primeiros donatários, Duarte Coelho e seus sucessores; pela constituição de suas elites, originárias dos sucessores de Jerônimo de Albuquerque e dos "muitos gentis homens, fidalgos e bons colonos" que aqui aportaram a partir de 1535; pela sua proximidade com portos da Europa e ligações com a África; pela sua contribuição na colonização e na conquista de todo o Norte do Brasil, ainda nos difíceis anos do século XVI; pelo espírito aguerrido do seu povo, responsável pela suserania da coroa portuguesa nas capitanias do Norte, antes integrantes do Brasil Holandês (1630-1654)". SILVA, Leonardo Dantas. Bento Teixeira e os outros pioneiros das Letras em Pernambuco. Ci. \& Tróp., Recife: v 26, a. 2, p. 303-31 0, juL/dez., 1998.

145 "[...] considerando a criação épica de Camões, onde os deuses não são categoria real, mas sim puros entes de ficção, Bento Teixeira cria um plano onde o destronado ente fabular Proteu deixa a condição de fábula para ser pessoa. Só assim, depois de Camões e sob a égide de Ovídio, ele pode ser animado”. ALVES, Luiz Roberto. Matéria ordenada e matéria inacabada. In: A Fábula em busca da história. Relações entre as narrativas manuscritas de Bento Teixeira e o poema Prosopopeia. São Paulo: USP, Dissertação de Mestrado, 1977. P. 65.

146 "O poeta imita pessoas, coisas e eventos, como os que se encontram na história. Mas não os mesmos: a história narra sucessos ocorridos, já singularizados em sua ocorrência, enquanto o poeta os 
marinhas da Antiguidade, tecendo sua previsão, com respaldo no evento histórico e nos feitos do clã dos Duarte.

Conforme Andrea Ciacchi nos lembra, Bento Teixeira, réu da Santa Inquisição, olha para a Colônia a partir de um ângulo inédito, o de um homem livre, "ainda não brasileiro, porém não mais português, exemplo de intelectual laico", entre dois universos simbólicos, entre duas religiões às quais pertence:

O autor da Prosopopeia consegue mandar para um dos maiores editores portugueses da época, um poemeto em oitavas camonianas compostas no Brasil, mas que acolhe todas as características e os elementos do mais amplo sistema épico nacional, todo português, mas

do qual Bento Teixeira, embora exilado "além-mar", é um dos primeiros representantes. Em Olinda, aceita todas as convenções literárias que naquele período, menos de vinte anos após a publicação d'Os Lusíadas, estavam estruturando a nova fase de um gênero, o poema épico, que, justamente depois de Camões, já nascia epigônico;

E ainda:

A primeira e maior parte da trajetória existencial desse homem se desenvolve toda no Brasil, onde ele é testemunha da instalação da

Visitação Inquisitorial. Isso acontece enquanto ganha corpo o processo colonizador português, do qual são forças históricas a experiência das Capitanias, a Sucessão dos Governos Gerais, o ciclo do pau brasil e o da cana de açúcar, a catequese e s lutas contra franceses, holandeses e ingleses, interessados em participarem das riquezas da nova terra, e contra os povos indígenas, avessos, na maioria dos casos, a aceitarem pacificamente o projeto colonial português e o projeto apostolar dos Jesuítas. De tudo isso quase não existem marcos na Prosopopeia, que, ao contrário, é toda voltada para a metrópole. ${ }^{147}$

narra "verossímeis" e "possíveis", nunca esgotados na sua possibilidade de reunir significados." $\underline{\mathrm{E}}$ ainda: "Verossímil, "semelhante ao verdadeiro", um conceito que só pertence junto ao de imitação". MUHANA, Adma Fadul. A Epopeia em Prosa Seiscentista: uma definição de Gênero. São Paulo: Tese de Doutoramento, 1996. P. 24.

147 CIACCHI, Andrea. A Prosopopeia de Bento Teixeira: Materiais e Apontamentos para uma Revisão Historiográfica. João Pessoa: UFPB, 1997. 
Nesse sentido, os fatos narrados no poema ocorreram num tempo histórico, não da forma como apresentados pelos documentos, mas aqui transformados sob o signo da invenção, por meio da fantasia poética. Os versos não encontram respaldo na história somente, mas na poética do criar, do mesclar e do circular saberes épicos no sentido de confundir verdade e verossimilhança ${ }^{148}$, entre o narrar e o versar, numa alegoria que pinta o cenário colonial a partir de Olinda $^{149}$, pelas mãos um poeta capaz de desafiar a lei instaurada pelas letras de quem conhece as condicionantes de todo um processo em construção vigente entre a Nova e a Velha Lusitânia.

Observamos que no Prólogo ${ }^{150}$, "Dirigido a Jorge d'Albuquerque Coelho, Capitão e Governador da Capitania de Pernambuco, das partes do Brasil da Nova

148 Aqui recolhemos a diferença entre Poesia e História, a partir de Aristóteles: "a Poesia encerra mais filosofia e elevação do que a história; aquela enuncia verdades gerais; esta relata fatos particulares. Enunciar verdades gerais é dizer que espécie de coisas um indivíduo de natureza tal vem a dizer ou fazer verossímil ou necessariamente; a isso visa a Poesia, ainda quando nomeia personagens. Relatar fatos particulares é contar o que Alcibíades (Fulano, nota do Tradutor Jaime Bruna) fez ou o que fizeram a ele.” Aristóteles, Poética. IX. In: A Poética Clássica. São Paulo: Editora Cultrix, 2011.

149 Com a fundação do Colégio dos Jesuítas em Olinda (1551), surge em Pernambuco um centro educacional que viria a formar as gerações, não somente na iniciação à alfabetização e ao catecismo da doutrina cristã, bem como nos rudimentos da matemática, mas também no latim, na filosofia e na moral, matérias estas cujas aulas tiveram início em julho de 1568 pelo padre João Pereira. Em 1800 o prédio do antigo Colégio dos Jesuítas vem a ser ocupado pelo Seminário Episcopal de Nossa Senhora da Graça, cujos estatutos foram elaborados pelo bispo D. José Joaquim da Cunha de Azeredo Coutinho (Lisboa: Tipografia da Acad. R. das Ciências, 1798), com a finalidade de instruir "a mocidade em todos os seus principais ramos da literatura, própria não só de um eclesiástico, mas também de um cidadão que se propõe a servir ao Estado". E-: "O seminário, chamado pelo cônego Barata de "escola de heróis", veio a ser o principal propagador do ideário ilusionista dos filósofos franceses nas capitanias do Norte do Brasil." SILVA, Leonardo Dantas. Bento Teixeira e os outros pioneiros das Letras em Pernambuco. Cia. \& Tróp, Recife, v 26, a. 2, p. 303-31 0, jul /dez., 1998.

150 “A relação entre poesia e memória, presente no Prólogo, e reiterada muitas vezes ao longo do próprio poema, ecoa uma tradição que remonta aos antigos, particularmente à famosa ode de Horacio": Um monumento mais que o bronze eterno”.

E que reais pirâmides mais alto Arrematei, que nem voraz dilúvio, Àquilo iroso ou série imensa de anos 
Lusitânia, etc.", Bento Teixeira faz uso do preceito horaciano "Ut Pictura Poesis", com o objetivo de alcançar seu objetivo: compor a paisagem a partir dos versos, a exemplo do artista no momento de criação do retrato, ao selecionar pincéis, tons e moldura, com destreza e perícia, a partir de um rascunho luso-brasileiro aqui denominado como Nova Lusitânia, Olinda.

Sabemos que a narrativa da epopeia trata da ação heróica de tipos ilustres, sob o signo da guerra, da religião e da virtude, uma vez que recupera a concepção dos valores da Antiguidade. Ao narrar, segundo seu interesse e escolha, fatos, ilustrações e imagens que Bento julga relevantes para compor o cenário de um mundo por ele concebido, realiza a épica da memória.

Nesse sentido, Jairo Luna ${ }^{151}$ entende o conceito de memória a partir da épica, com base na terminologia proposta pelos estudos dos irmãos Campos ${ }^{152}$ sobre Sousândrade e Ezra Pound, como condição em que o narrador escolhe, mediante interesse, ordem e importância dos fatos narrados, reservando-lhes o espaço que julgar necessário no poema, "no sentido de que o fluxo da memória é que dá o tom à narrativa e não a preocupação histórico-cronológica”.

Para melhor compreensão da concepção de Mundo Épico, Jairo lembra-nos que, para a tradição clássica desse gênero, temos em Homero o seu principal modelo e que ele tem a favor de si, o distanciamento no tempo, o berço cultural e o fato de ser o primeiro:

Nem dos tempos a fuga estragar possa.

MOREIRA, Marcello. Louvor e História em Prosopopeia.

151 LUNA, Jairo. Retórica da Poesia Épica. (De Bento Teixeira a Sousândrade). São Paulo: DLCVUSP, 1997.

152 “Trata-se, pois, de uma "plotless epic”, de uma verdadeira épica de memória, sem uma sucessão cronológica de eventos, mas segundo o delineamento de focos de interesse. Por essa razão, talvez, sentia o poeta a rebeldia de seu poema a uma classificação ortodoxa de gêneros de composição, preferindo apelar para a ideia de narrativa". CAMPOS, Augusto e Haroldo de. Ver. de Souzândrade. Rio de Janeiro: Nova Fronteira, 1986. P. 40. 
Seguem-se Virgílio, Tasso, Ariosto, Camões como representantes de modelos clássicos. As nações europeias que herdaram da cultura grega o conceito de épica a partir de Homero, elegeram as obras desses poetas como verdadeiros símbolos nacionais. ${ }^{153}$

Ainda, percebemos que o poeta imitava opiniões consideradas como verdadeiras nos campos da semântica e da atividade discursiva e se colocava como um artífice capaz de compor um estilo, ao inventar um poema com forma análoga, mediante engenho e arte, com base numa retórica greco-latina.

As epopeias reproduzem o corporativismo da hierarquia da sociedade da corte. Acerca do mundo camoniano, Alcir Pécora nos lembra sobre os efeitos que a épica é capaz de construir, a partir da condição de louvor. Proteu ${ }^{154}$, deus dos mares, opera essa exortação como necessária, a título de defesa ao construir

efeitos tão desolados e contrários em tudo ao que se esperaria de um canto de louvor à pátria. Uma pátria, de resto, que, no presente da enunciação, produz-se sem quase traço da antiga grandeza que dera causa ao canto. ${ }^{155}$

A poesia épica luso-brasileira do século XVI considera como público o Estado, como corpo político. Não há que se falar na individualidade de leitores, até porque não havia a condição de circulação, publicação e leitura dessas obras.

Uma das funções da épica era a teatralização. A história como grande fomento, o que sugere a epopeia retratar a dramaticidade dos episódios por meio de uma

153 Luna, Jairo. Idem, p. 20.

154 “Divindade Marinha encarregada do pastoreio dos rebanhos pertencentes a Poseidon. Podia, como muitos outros deuses do mar, metamorfosear-se no que desejasse, habilidade de que se valia para escapar àqueles que lhe dirigiam perguntas. Tinha o dom da profecia, mas se recusava a prestar informações àqueles que o buscavam”. TEIXEIRA, Ivan. Multiclássicos Épicos. Prosopopeia. O Uraguai. Caramuru. Vila Rica. A Confederação dos Tamoios. I-Juca-Pirama. São Paulo: Edusp. Imprensa Oficial, 2008.

155 PÉCORA, Alcir. Máquina de Gêneros: novamente descoberta e aplicada a Castiglione, Della Casa, Nóbrega, Camões, Vieira, La Rochefocauld, Gonzaga, Silva Alvarenga e Bocage. São Paulo: EDUSP, 2001, p. 141. 
narrativa, por vezes dramática, com finalidade de apresentar proezas para serem admiradas. Trata-se de poesia escrita para ser lida, aqui vista como prática poética lusobrasileira nutrida de elementos aristotélicos que alcançam a temática dos elementos cristãos e indígenas.

O gênero em circulação ${ }^{156}$ se baseia nas três funções indo-européias: soberania, força e fecundidade, o que explica que os heróis derivem de deuses ou figuras míticas. A imitação pretende também um discurso narrativo longo.

Bento Teixeira como um criador que aprendeu uma lição retórica de singular valor, vigente atitude maneirista que abre a porta para o Barroco: o estilo é que metamorfoseia o conteúdo, e isto a tal ponto que as palavras e as ideias com que o poeta joga podem dar-lhe prazer mesmo perante certos desgostos. ${ }^{157}$

A poesia épica ${ }^{158}$ também é narração, mas composta segundo a verossimilhança de ações humanas memoráveis. Entretanto, a poesia é mais filosófica do que a história, pois não narra particularidades e verdades dos eventos que ocorreram,

156 “O herói português e espanhol, mesmo quando vive momentos de crise, representava-os através da glória. Camões, por exemplo, utilizava-se de Vasco da Gama para compor o perfil do Estado português, figura básica da representação ibérica, necessária à construção épica.” Theodoro, Janice. A Cultura Ibérica e seu contraponto inglês. Descobrimento da América: A Comemoração como o Narciso da Cultura Latino-Americana. In: América Barroca. São Paulo: Editora Nova Fronteira /Edusp, 1992. P.04.

157 ALVES, Luiz Roberto. A fábula e a história. In: A Fábula em busca da história. Relações entre as narrativas manuscritas de Bento Teixeira e o poema Prosopopeia. São Paulo: USP, Dissertação de mestrado, 1977. P. 200.

158 "A ideia de que uma tradição seja capaz de reproduzir uma narrativa épica extensa e homogênea sem a cooperação de um poeta consciente e deliberadamente criativo, e de capacitar alguém para recontar, exaustivamente e de maneira coerente, tais histórias, é um rematado absurdo. Uma narrativa bem acabada e homogênea, por mais rudimentar que seja a forma nem que se apresente, deixe de ser uma saga para converter-se num poema, e aquele que o diz pela primeira vez é seu criador". HAUSER, Arnold. Os Poetas Épicos e seu Público. In: Idade Média. In: História Social da Arte e da Literatura. São Paulo: Martins fontes, 1995. P.165. 
mas põe em cena o universal, o tipo de coisa que determinados homens diriam e fariam conforme a necessidade de seu caráter.

A figura prosopopeia é a marca da personificação; é quando, por exemplo, no desfile dos seus atos também os entes fabulários metamorfoseiam o seu agir passando ao modo humano. Assim, pela nova fórmula a fábula adquire consistência de história. Retoricamente a prosopopeia consistirá num instrumento forjado e refinado para contar verdades renovadas, as quais já não tem voz pela sua própria natureza e força. ${ }^{159}$

159 ALVES, Luiz Roberto. Matéria ordenada e matéria inacabada. In: op. cit,. P. 221. 


\section{1.a Descrição do Recife}

\section{XVII}

Para a parte do sul, onde a Pequena

Ursa ${ }^{160}$ se vê de guardas rodeada,

onde o céu luminoso mais serena

tem sua influïção, e temperada;

influência

Junto da Nova Lusitânia ordena

Olinda

A natureza, mãe bem atentada,

Um porto tão quieto e tão seguro,

Que para as curvas naus serve de muro.

\section{XVIII}

É este porto tal, por estar posta

Uma cinta de pedra, inculta e viva,

Ao longo da soberba e larga costa,

160 Ursa Maior e Menor são duas constelações invisíveis a partir do hemisfério sul. Teriam surgido das metamorfoses sofridas por Calisto e por seu filho Arcas. Calisto era companheira de Ártemis e votou permanecer virgem. No entanto, foi violentada por Zeus, que a enganou, ao disfarçar-se de irmã de Apolo. Um dia, obrigada a desvestir-se diante de Ártemis, que se banhava em uma fonte com ninfas, revelou-lhe sua gravidez. A deusa para puni-la transformou-a em uma ursa. Arcas, criado por Maia, saiu a caçar depois de crescido e deparou-se com sua mãe. Perseguiu-a até o templo de Zeus, em que adentrou, o que lhe valeu a pena de morte pelo sacrilégio cometido. Zeus, penalizado, metamorfoseou ambos em constelações, dando-lhes Arcturo como guardião. TEIXEIRA, Ivan Prado (org.) e PARRON, Tâmis (rev.) Glossário. In: Prosopopeia. Multiclássicos. Épicos. .São Paulo: Edusp, 2008. P.1212, 1213. 
Onde quebra Netuno ${ }^{161}$ a fúria esquiva.

fugir

Entre a praia e pedra descomposta,

O estanhado elemento se deriva

Com tanta mansidão, que uma fateixa âncora

Basta ter à fatal Argos ${ }^{162}$ aneixa. anexa

\section{$X I X$}

Em o meio desta obra alpestre e dura,

Uma boca rompeu o mar inchado,

Que, na língua dos bárbaros escura,

Pernambuco de todos é chamado.

De para'na, que é mar; puca, rotura,

Feita com fúria desse mar salgado,

Que, sem no derivar cometer míngua,

Cova do mar se chama em nossa língua.

\section{$\boldsymbol{X} \boldsymbol{X}$}

Pela entrada da barra, à parte esquerda,

Está uma lajem grande e espaçosa,

161 Nome latino dado à divindade oceânica que os gregos chamavam Poseidon. Senhor dos mares, comandava as ondas, provocava tempestades no mar e, com um golpe de seu tridente, fazia a água brotar do solo. Estendia seu império sobre fontes e lagos, embora os rios estivessem sob o domínio de outros deuses. Era conduzido em um carro puxado por hipocampos. Teve inúmeros filhos, muitos deles perversos e violentos. De Toosa, por exemplo, teve o ciclope Polifemo e, de Medusa, o gigante Crisaor e Pégaso. TEIXEIRA, p. cit., p.1195.

162 'au de origem lendária, daí a palavra Argonauta = tripulante, marujo, marinheiro. TEIXEIRA, p. cit., p.1161. 
Que de piratas fora total perda,

Se uma torre tivera suntuosa.

Mas quem por seus serviços bons não herda,

Desgosta de fazer cousa lustrosa,

Que a condição do Rei que não é franco

O vassalo faz ser nas obras manco.

\section{$X X I$}

Sendo os Deuses à lajem já chegados,

Estando o vento em calma, o mar quieto,

Depois de estarem todos sossegados,

Por mandado do Rei e por decreto,

Proteu $^{163}$, no céu c'os olhos enlevados,

Como que investigava alto secreto,

Com voz bem entoada e bom meneio,

Ao profundo silêncio larga o freio.

\footnotetext{
163 Divindade marinha encarregada do pastoreio dos rebanhos pertencentes a Poseidon. Podia, como muitos outros deuses do mar, metamorfosear-se no que desejasse, habilidade de que se valia para escapar àqueles que lhe dirigiam perguntas. Tinha o dom da profecia, mas se recusava a prestar informação àqueles que o buscavam. TEIXEIRA, p. cit., p.1202.
} 


\section{IV.1.b Soneto}

Bento Teixeira, em Prosopopeia, também nos oferta um soneto.

\section{SONETO POR}

Ecos, ao Mesmo Senhor Jorge

D'Albuquerque Coelho

Gran Jorge, por su ser llamado - Amado,

Querer mi Verso celebrarte, - Arte

Ni cuanto el Cielo acá reparte, - Parte

Menor, dirán, de tu sagrado - Grado;

Por lo que has con valor sobrado - Obrado,

Se ocupa siempre en sublimarte - Marte,

Y para en algo acomodarte, - Darte

Quiso tan alto y recuestado - Estado;

Tu eres la gloria y la columna, - Luna

De Lusitania y refulgente - Gente,

Por quien llamarse venturosa - Osa;

Y el Cielo que tal don consiente, - Siente

Que te dio por suerte oportuna - Una

Señora excelsa y grandiosa - Diosa.

\section{LAVS DEO}


Observamos que há toda uma discussão crítica acerca da recepção da Prosopopeia, uma vez que não integra o corpus do cânone brasileiro, não recebe a chancela de literatura brasileira ou luso-brasileira ou portuguesa pelo plano da história da arte ou da literatura.

"Desde o século XIX, a crítica que se ocupa da poesia atribuída a Gregório de Matos e de outros discursos coloniais penso, por exemplo, em Anchieta, Nóbrega, Bento Teixeira, Vieira, Manuel Botelho de Oliveira, Cláudio Manuel da Costa, Basílio da Gama, etc. costuma ignorar e eliminar sistematicamente suas categorias, substituindo-as por outras, que universalizam valores interessados do presente dos intérpretes". ${ }^{164}$

No entanto, reiteramos a circunstância em que pensamos o poema, na condição de texto sequestrado dos estudos coloniais, como letras necessárias para serem percebidas, diante de um inventário de questões possíveis que Ela suscita. Não tomamos partido quanto a uma condição de texto integrante de nossa formação, como literatura brasileira, porque "sequestrada" do barroco; deixamos a questão em aberto, até porque o debate não se encerra e porque o importante é a provocação, como convite à leitura e à reflexão.

Pensamos para além dessa questão. Como a poética colonial dialoga com os estudos clássicos e a chave literária de interpretação caminha pela dialética do mito, bem como pela contribuição do vernáculo colonial ${ }^{165}$, como corpus integrante dos estudos literários.

A função em jogo está lançada: como mediar a interpretação desses saberes para um leitor cada vez menos habilitado à percepção do mundo, com o qual integra e o quanto língua e literatura funcionam como contributos legítimos para a cultura.

Sabemos que querelas entre o que é literatura e o que não é ajuda-nos a pensar, como educadores, nas grandes demandas do que ser ensinado na sala de aula e como

164 HANSEN, João Adolfo. Letras Coloniais e Historiografia Literária. Rio de Janeiro: UERJ, 2015.

165 MARTINON, Jean-Pierre. Id. , 1977. 
ensinar conteúdos sofisticados pela visão de mundo e fortuna linguística que ensejam. Levantam questões como produção, difusão e consagração de textos literários ou obras já festejadas no mercado de saberes e aprendizagens de objetos simbólicos que a escola está apta ou não a compartilhar. Ficamos, por ora, com o pensamento de Gilberto Freyre: "o tempo poetiza as pessoas e as coisas". 


\section{IV.2. Mundo Narrativo}

"Ainda que tudo o que sabemos do passado fosse certo, seria menos do que nada em relação ao ignorado. Quão pequeno e imperfeito éo conhecimento que mesmo os mais curiosos têm de nosso tempo"!

Montaigne ${ }^{166}$

A leitura de um texto colonial ${ }^{167}$ nos convida a pensar por teias aparentemente conexas e ao mesmo tempo ardilosas uma vez que, como leitores ${ }^{168}$,

166 Montaigne nos alerta no sentido de se atentar também para o que Sólon diz ter ouvido dos sacerdotes egípcios acerca da história de seu país, dos países estrangeiros e dos métodos de escrevê-la: "Se pudéssemos ter sob os olhos a extensão infinita das terras e dos tempos em que o espírito mergulha e que percorre sem encontrar limites, aí descobriríamos um sem número de formas (Cícero)”. MONTAIGNE, Michel de. Ensaios. São Paulo: Abril Cultural, 1972. P. 416.

167 "A ação colonizadora reinstaura e dialetiza as três ordens: do cultivo, do culto e da cultura. A ordem do cultivo, em primeiro lugar. As migrações e o povoamento reforçam o princípio básico do domínio sobre a natureza, peculiar a todas as sociedades humanas. Novas terras, novos bens abrem-se à cobiça dos invasores. Reviva-se o ímpeto predatório e mercantil que leva à aceleração econômica da matriz em termos de uma acumulação de riquezas em geral rápida e grávida de consequências para o sistema de trocas internacional. Pode-se calcular o que significou para a burguesia europeia, em pleno mercantilismo, a maciça exploração açucareira e mineira da América Latina. Se o aumento na circulação de mercadorias se traduz em progresso, não resta dúvida de que a colonização do Novo Mundo como um agente modernizador da rede comercial europeia durante os séculos XVI, XVII e XVIII. Nesse contexto, a economia colonial foi efeito e estímulo dos mercados metropolitanos na longa fase que medeia entre a agonia do feudalismo e o surto da Revolução Indústria". BOSI, Alfredo. Colônia, Culto e Cultura. Dialética da Colonização. São Paulo: Companhia das Letras, 2002. P.19 e 20.

168 “Desde sua primeira viagem, com base nas analogias entre o que tinha diante de si e o que lera em autores como Mandeville, Colombo procuraria provar que chegara nas imediações do Paraíso Terrestre". SOUZA, Laura de Mello \&. O diabo e a Terra de Santa Cruz. São Paulo: Companhia das Letras, 2005, P.37. 
podemos nos perder entre as muitas chaves de interpretação: mundos criados que se escondem por labirintos ${ }^{169}$ ou se disfarçam por meio de espelhos ${ }^{170}{ }^{171}$, entre os espaços da fábula ${ }^{172}$, da memória ou da história.

Na condição de argonautas de primeira viagem, embarcamos no jogo de tomar o atalho mais seguro, imaginando por conta e risco, tudo o que conseguimos captar pelas mãos do autor, o qual nos conduz, mediante artífice, por narrativas ${ }^{173}$ que nos levam a percorrer caminhos, por letras que narram experiências vividas, mas

169 "Un examen de los grandes mitos humanos relativos al origen de la especie y al sentido de nuestra presencia en la tierra, revela que toda cultura - entendida como creación y participación comum de valores - parte de la convicción de que el orden del universo há sido roto o violado por el hombre, el intruso. Por el "hueco" o abertura de la herida que el hombre há infligido em la carne compacta del mundo, puede irrumpir de nuevo el caos, que el estado antiguo y, por decirlo así, natural de la vida". PAZ, Octavio. El Pachuco y otros extremos. In: El laberinto de la soledad. Madrid: Catedra, 2004. P.161.

170 MORSE, Richard M. Os Pioneiros. "Aprendi a valorizar seriamente a literatura para explicar (...) como funcionam as sensibilidades..." In MEIHY, José Carlos Sebe Bom. "A Colônia Brasilianista: História oral de vida acadêmica". São Paulo: Nova Stella, 1990. P. 139-161.

171 As novas colônias começaram, ou seus atores tiveram a sensação de começar, a partir de uma base nova, sensação que deforma boa parte da historiografia do Novo Mundo. MORSE, Richard M. Novo Mundo: Dois Mundos. O Espelho de Próspero. Cultura e Ideias nas Américas. São Paulo: Companhia das Letras, 1988. P.23.

172 "Algumas coisas, porém, não viu, mas escutou-as de outros homens sinceros e verdadeiros. Portanto, nos referimos às coisas vistas por vistas e às ouvidas por ouvidas, para que nosso livro seja fiel, sem artifícios, enganos e para que as aventuras que aqui se descrevem não sejam tomadas por fábulas". POLO, Marco. Aqui começa a introdução do livro denominado: A Descrição do Mundo. Livro Primeiro. In: $O$ Livro das Maravilhas. Porto Alegre: L\&PM, 2015. P.35.

173 "A antiga preceptiva, que ainda chegava a distinguir fontes narrativas de fontes não narrativas foi inteiramente diluída pela afirmação de que, a rigor, todas as fontes, consideradas ou não em seu nível linguístico, seriam fontes narrativas. Alguns historiadores mais afoitos, ávidos por retomar as "regras" de uma disciplina cuja linguagem e identidade estavam à deriva, partiram para transformar tudo em texto e encontrar no passado "estruturas de significado", "gabaritos simbólicos", "sistemas simbólicos" e outras variações". SALIBA, Elias Thomé. Documentos, Relíquias, Lembranças: Pequena História de Aventuras e Desencantos. IN: A Escrita da Memória. Leandro Karnal e José Alves Freitas Neto (org.) São Paulo: Instituto Cultural Banco Santos, 2004. P. 37. 
também documentam espaços coloniais cartografados com base nas memórias; se verdade ou imaginação, o quanto se tem de veracidade e o quanto as letras, ainda que não belas, mascaram pela invenção ${ }^{174}$.

Janice Theodoro, em como fundir o relato histórico com o relato literário?, ajuda-nos a pensar que a melhor maneira de trabalhar o documento histórico, passa pela percepção da narração presente ao texto, vozes e discursos articulados entre fatos, o que colhemos como ciência ou o que recolhemos como imaginação, trazendo-nos elementos para um bom debate entre os campos da História e da Literatura enquanto disciplinas.

Segundo ela, a análise de um documento e a análise literária muito se parecem uma vez que "veracidade" e "imaginação" constituem elementos do texto histórico:

"A presença alternada, combinada e espelhada torna muitas vezes dificil, ao historiador, separar o fato propriamente dito, do que é imaginação, ou que se transformou de imaginação em fato documentado (descobrimento da América) ou ainda, o que foi um fato distorcido, apenas um pouquinho, pelo olhar do narrador, daquele que foi muito distorcido". ${ }^{175}$

Ao analisar relatos históricos, Janice parte dos pressupostos estudados por Walter D. Mignolo:

"veracidad y ficcionalidad se conciben, en mi sistema conceptual, como convenciones que regulan el empleo del lenguaje, literatura e historia se conciben como normas que regulan el empleo del lenguaje en una práctica discursiva disciplinaria". ${ }^{176}$

\footnotetext{
174 "Colombo, pois, vive e atua no âmbito de um mundo em que a América, imprevista e imprevisível, era, em todo caso, mera possibilidade futura, mas da qual, nem ele nem ninguém tinha ideia, nem poderia tê-la”. O’Gorman, Edmundo. O Processo de Invenção da América. A invenção da América. São Paulo: Editora UNESP, 1992. P. 99.
}

175 Theodoro, Janice, op. cit., p. 17.

176 MIGNOLO, Walter D. "Dominios Borrosos y Dominios Teóricos: Ensayo de Elucidación Conceitual". Buenos Aires, Facultad de Filosofia y Letras, ano xx, 1985, PP.21-40. 
Nesse sentido, a função do narrar e do compor imagens de um viajante que se desloca por espaços e escreve, mais do que o simples desenho ou o arrolamento das memórias, é capaz de cartografar terras e valores sociais.

Ao fixar-se por lugares desconhecidos, e procura estabelecer relações humanas, identifica valores sociais circulantes; enquanto narra e registra a composição das grandezas, percebe a economia e os bens em circulação e, sobretudo, a composição do tecido social do qual hoje somos parte, hoje nomeado ${ }^{177}$ como Brasil $^{178}$.

Ainda, traz-nos condicionantes de uma sociedade que se formava a partir da monocultura do açúcar ${ }^{179}$, monopólio de produção de circulação de riquezas e, sobretudo, de pessoas, diante do domínio europeu.

Buscar, pela leitura das letras coloniais, a percepção de como a paisagem colonial se coloca, bem como interpretar a narrativa com base no contexto em que a obra foi produzida, é um ofício a ser realizado não apenas por historiadores, antropólogos e naturalistas, mas por qualquer leitor interessado em perceber como um

177 “A nomeação equivale a tomar posse". E: "Há dias em que esta obrigação deixa Colombo num estado de verdadeiro furor nominativo." Ainda: “A parte da comunicação humana que prende a atenção de Colombo é, pois, precisamente o setor da linguagem, já que vê os nomes confundidos às coisas: toda a dimensão de intersubjetividade, do valor recíproco das palavras, do caráter humano e, portanto arbitrário, dos signos lhe escapa". TODOROV, Tzvetan. Colombo Hermeneuta. In: A Conquista da América - a questão do outro. São Paulo: Martins Fontes, 1988. P. 27, 28.

178 "O agente da Sereníssima, que assistiu em Lisboa ao regresso da frota de Pedro Álvares Cabral, alude, já em 1501, àquela “terra delli Papagá” e do Crético ou de alguma outra fonte passaria esse nome, devidamente latinizado, até às cartas geográficas. Só mais tarde começaria a prevalecer, generalizando-se, o de terra do Brasil”. HOLANDA, Sergio Buarque de. Visão do Paraíso. São Paulo: Editora Brasiliense, 2002. P.212.

179 “Nos três primeiros séculos da colonização da América, será, entretanto, o açúcar o móvel quase único da colonização dos trópicos. E: A Coroa Portuguesa empenhará um grande interesse pelo desenvolvimento da produção açucareira no Brasil. Foi criada uma honraria especial, que valia por um título - o de "senhor de engenho" - concedida especialmente por Sua Majestade". FURTADO, Celso. A Economia da Cana de Açúcar. In: Economia colonial no Brasil nos séculos XVI e XVII. São Paulo: HUCITEC, 2001. P.95-96. 
mundo narrado inclui a tradução da paisagem percebida por Koster, ao começar seu desenho por Olinda.

A cidade de Olinda é construída sobre um outeiro: sua situação, observada do mar, é do mais agradável efeito. Igrejas e conventos que se elevam sobre os cimos e os flancos da colina, seus jardins e suas árvores, semeados aqui e além entre as casas, dão a mais alta

ideia de sua beleza e extensão. ${ }^{180}$

Ler e compreender como o autor consegue dar conta do processo narrativo ao compor e ilustrar a paisagem, obra traduzida por um folclorista, é tarefa desafiadora ao leitor ${ }^{181}$, por se tratar de uma narrativa densa, farta, memorialista, com grandezas e curiosidades inventariadas por um olhar que registra práticas e costumes, circula um gênero textual vigente; retrata uma sociedade majoritariamente iletrada, ao mesmo tempo em que nos informa que possuir o domínio da letra, significa possuir poder.

Surpreendente aos ingleses que em uma praça tão grande como Recife não exista uma tipografia nem um mercado de livros. ${ }^{182}$

Aqui é preciso que o leitor se permita perceber que tem diante de si uma viagem narrada para além do campo da história, sobretudo da memória, da oralidade de quem conviveu no espaço descrito. Necessário se faz realizar o trânsito pelas palavras, sem tomar partido, com cautela, pois há que se decifrar práticas e costumes singulares a um tempo e a um espaço. Não podemos viajar na leitura dessa obra com olhos estáticos 180Koster, H. Partida de Liverpool. Chegada a Pernambuco. Jangadas. Recife. O Governador. O Comércio. In: Viagens ao Nordeste do Brasil. São Paulo: Companhia Editora Nacional, 1942. P. 30.

181 "O "onde" da leitura é mais importante do que se poderia pensar, pois a colocação do leitor em seu ambiente pode dar sugestões sobre a natureza e sua experiência.". DARNTON, Robert. História da Leitura. In: A Escrita da História. Novas Perspectivas. Peter Burke (org.) São Paulo, UNESP, 1992. P. 213.

182 Idem, p. 68. 
do presente ou da teoria pronta, acadêmica, de quem lê a Viagem na qualidade de mero documento ou fonte de pesquisa. Reiteramos que há que se permitir uma dialética da mediação, com base na evidência dos discursos circulantes. Assim se faz o caminho, ao caminhar... ${ }^{183}$

Em meio caminho, fomos pelas margens do Capibaribe. A vista é excessivamente encantadora, casas, árvores, jardins de cada banda.

$O$ rio faz a curva deante e parece perder-se no meio da mata. As canoas indo docemente descem com a maré, ou penosamente forcejam seu caminho contra a corrente, e tudo reunido forma um espetáculo delicioso. O rio aqui é mais estreito que o Tamisa em Richmond.. Ao lado da estrada, neste ponto, estão várias negras vendendo laranjas e

outras frutas e bolos aos canoeiros, com seus compridos varapaus que, incapazes de perder tempo, compram e vendem provisões. Era a primeira vez que deixava a cidade e fiquei verdadeiramente agradado desse aspecto do país, do qual me tornara habitante. Deixamos o rio, continuando pela estrada sempre bordada de casinhas, de melhor ou peor aparência, até um pequenino vilarejo que atravessamos, chegando ao fim da nossa jornada. A situação é muito pitoresca, na margem norte do Capibaribe, ao pé de uma colina, coberta de vegetação. ${ }^{184}$

Decifrar esse contexto por meio do texto, a possibilidade de atalho que comunica letras com outros campos do conhecimento, feita por uma estratégia transdisciplinar de interpretação, promovendo uma relação pendular entre os campos da literatura e da história, eis uma possibilidade para se pensarem sujeitos e discursos, imagens de uma Olinda como espaço atravessado ${ }^{185}$, como território entre a literatura e a cultura, herança legítima do caldo de saberes.

183 Caminante, son tus huellas / El camino, y nada más; / Caminate, no hay camino, / Se hace camino al andar. MACHADO, Antonio. XXIX. .Proverbios y Cantares. In: Poesías Completas. Madrid: Espasa, 2010. P.232-233.

184 Idem, p. 44.

185 "Indagar sobre as representações da cidade na cena escrita construída pela literatura é basicamente, ler textos que leem a cidade, considerando não só os aspectos físicos-geográficos (a paisagem urbana), os dados culturais mais específicos, os costumes, os tipos humanos, mas também a cartografia simbólica, em que se cruzam o imaginário, a história, a memória da cidade e a cidade da 
O número de funcionários civis e militares é enorme; inúmeros inspectores sem objeto a inspeccionar, um sem-fim de coronéis sem regimento para comandar, juizes para dirigir cada ramo da administração, por menor que seja, serviços que podem ser feitos por duas ou três pessoas. Os vencimentos aumentaram, o povo está oprimido e o Estado não colhe benefício algum. Os impostos, pela maneira com que foram estabelecidos, pezam sobre as classes baixas e não alcançam quem os poderia suportar desafogadamente. ${ }^{186}$

As instituições públicas não são numerosas. Mas as que existem são excelentes. O Seminario de Olinda ${ }^{187}$ para a educação de rapazes, é bem dirigido e vários dos professores são pessoas de cultura e princípios liberais. É principalmente destinado ao preparo de

memória. É, enfim, considerar a cidade como discurso, verdadeiramente uma linguagem, uma vez que fala a seus habitantes: falamos a nossa cidade, onde nos encontramos, quando a habitamos, a percorremos, a olhamos como propõe Roland Barthes, no ensaio "Semiologia e Urbanismo". A cidade escrita é, então resultado da leitura, construção do sujeito que a lê, enquanto espaço físico e mito cultural, pensando-a como condensação simbólica e material e cenário de mudança, em busca de significação.Escrever, portanto a cidade, é também lê-la, mesmo que ela se mostre ilegível à primeira vista; é engendra uma forma para essa realidade sempre móvel. Mapear seus sentidos múltiplos e suas múltiplas vozes e grafias é uma operação poética que procura apreender a escrita da cidade e a cidade como escrita, num jogo aberto à complexidade". GOMES, Renato Cordeiro. Cartografias Urbanas: Representações da Cidade na Literatura Urbana. Revista da Cátedra Padre Antonio Vieira de Estudos Portugueses, Rio de Janeiro, n.1. PUC, 2002. http://www.let.puc-rio.br/unidades\&nucleos/catedra/ Acesso em 10 de junho de 2015.

186 Idem, p. 64.

187 “Com a fundação do Colégio dos Jesuítas em Olinda (1551), surge em Pernambuco um centro educacional que viria a formar as gerações, não somente na iniciação à alfabetização e ao catecismo da doutrina cristã, bem como nos rudimentos da matemática, mas também no latim, na filosofia e na moral, matérias estas cujas aulas tiveram início em julho de 1568 pelo padre João Pereira. Em 1800 o prédio do antigo Colégio dos Jesuítas vem a ser ocupado pelo Seminário Episcopal de Nossa Senhora da Graça, cujos estatutos foram elaborados pelo bispo D. José Joaquim da Cunha de Azeredo Coutinho (Lisboa: Tipografia da Acad. R. das Ciências, 1798), com a finalidade de instruir "a mocidade em todos os seus principais ramos da literatura, própria não só de um eclesiástico, mas também de um cidadão que se propõe a servir ao Estado". E: "O seminário, chamado pelo cônego Barata de "escola de heróis", veio a ser o principal propagador do ideário ilusionista dos filósofos franceses nas capitanias do Norte do Brasil”. SILVA, Leonardo Dantas. Bento Teixeira e os outros pioneiros das Letras em Pernambuco. Ci. \& Tróp., Recife, v 26, a. 2, p. 303-31 0, juL/dez., 1998 
estudantes para padres seculares da Igreja. Assim eles usam uma batina preta e um barrete, de forma peculiar, mas não é obrigatório que terminem tomando ordens.

Escolas gratuitas foram fundadas em vários pontos do interior e ensinam latim em muitos desses cursos, mas a maior parte da instrução consta de leituras, escrita e aritmética. Mas essas escolas nem o Seminario exigem pagamento para os alunos. ${ }^{188}$

O Hospital de Lazaro é negligenciado, mas recebe inúmeros doentes e os outros estabelecimentos no gênero estão em um estado verdadeiramente miserável. É extranho que tantas igrejas formosas sejam construídas e deixem perecer uma multidão de doentes a falta de um edifício conveniente para abrigá-los. A melhor instituição de que Pernambuco se pode orgulhar, como a Mãe Pátria, é a Roda dos

Engeitados. Crianças de nascimento clandestino são recolhidas, tratadas, educadas e colocadas socialmente.

O Santo Ofício ou Inquisição jamais se estabeleceu no Brasil, mas residem em Pernambuco muitos padres, empregados como familiares e várias pessoas julgadas responsáveis por esse horrivel Tribunal foram enviadas presas para Lisboa. O Tratado de Aliança e Amizade entre as Coroas da Inglaterra e de Portugal, assinado no Rio de Janeiro em 1810, determinou, peremptoriamente, que o poder da Inquisição não seria reconhecido no Brasil . ${ }^{190}$

Nesse sentido, George Dantas ${ }^{191}$ propõe-nos uma leitura das Viagens de Koster, na condição de "leituras que viajam no tempo e no espaço", como produção fundamental para a formulação de representações sobre as cidades brasileiras, por meio do relato de um viajante que, com o "olhar de fora", realizou a experiência da leitura pela experimentação, ao descrever paisagens de uma sociedade em mudança.

188 Idem, p. 66.

189 Ortografia e acentuação adaptadas. Idem, p. 66, 67.

190 Idem, p. 68.

191 DANTAS, George Alexandre Ferreira. Leituras Viajantes. In: A cidade colonial entre olhares estrangeiros. A Formação das Representações sobre a cidade colonial no Brasil. São Carlos: EESC USP, Tese de Doutorado, 2009. 
Koster, ao relatar, segundo Dantas, é copioso, movido pelo interesse pelo detalhe e pelo anedotário, com pormenores que muito bem ilustram sua experiência entre o viajar e o escrever:

afinal, Koster nem era um artista que buscava ampliar sua paleta e experimentar para abarcar novas cores, formas e texturas; nem era o naturalista interessado em descobrir, catalogar, dissecar; muito menos o militar interessado em ampliar, detalhar e precisar a cartografia náutica; ou o colonialista pensando geopoliticamente; ou ainda o colecionador de coisas exóticas e pitorescas. P.86

Ainda:

Koster embrenha-se não apenas na geografia física do território, dos sertões, mas no território das práticas culturais (as festas religiosas, as novenas, o entrudo), ver de dentro, não apenas de fora-aponta muito mais para os interesses de Cascudo pela etnografia histórica, compulsando fontes antigas, recolhendo material que apontasse, direta ou indiretamente, para as tradições orais. Cascudo enfatiza mais ainda que este ver de dentro marcou a forma de observação de Koster: como na atitude desinteressada de tomar notas sentado na porta da casa grande ou cochilando no embalo da rede." $P .87$

Nesse sentido, a proposta estética sugerida por Otto Maria Carpeaux ${ }^{192}$, ao compor sua História da Literatura Ocidental, organiza o corpus literário histórico por meio de um panorama: convida o leitor a refletir sobre essa possibilidade de método como um "conceito moderno"; viaja entre paradigmas por meio de autores, obras e ideias e permite que o leitor embarque e recepcione a historicidade do texto, com base numa leitura que necessita dialogar amplamente com outros mundos literários ou não.

192 Para Carpeaux, Benedetto Croce não é o historiador de literatura, mas o filósofo cuja crítica literária é a aplicação dos princípios da sua estética, ou seja, o único objeto do estudo literário é a obra de arte, a qual deve ser estudada, abstraindo-se dos acessórios históricos e psicológicos que acompanham o processo poético e dos quais se encontram vestígios na obra”. 
Como bom observador anotava, com detalhes, tudo o que via em suas viagens e no seu dia-a-dia. Tomava parte da vida brasileira, conhecendo seu povo, seus usos e costumes, convivendo nas ruas com as mais diferentes camadas da população e freqüentando festas da sociedade local. ${ }^{193}$

Observamos, pois, a interface textual e historiográfica, a produção realizada por um inglês, filho de portugueses, que se desloca para viver no Brasil, para cuidar de sua saúde e que decide realizar viagens ao nordeste do Brasil, anotando, arrolando e comunicando informações sobre a terra, a gente e as relações sociais que se estabelecem nos anos finais do Brasil Colônia, sob o título "Travels in Brazil"194, Henry Koster ${ }^{195}$.

193 http://basilio.fundaj.gov.br/pesquisaescolar/index.php?view=article\&id=291:henry-

koster\&format=pdf\&option=com_content\&Itemid=187

194 “Mas quem escreveu sobre Pernambuco um livro que é uma delícia foi o inglês Henry Koster. Não era botânico nem geólogo nem missionário mas simplesmente inglês. Um inglês fraco do peito e por isso obrigado a procurar clima quente. O clima de Pernambuco não o curou; mas prolongou-lhe a vida $e$ ainda por cima deu-lhe força e disposição para escrever um dos melhores livros que existem sobre o Brasil: Travels in Brazil (1816). Livro de viagem dos bons, dos que se leem com gosto, como os romances. E quase todo sobre Pernambuco". Freyre, Gilberto. O Recife e os Ingleses. In: Guia Prático, Histórico e sentimental da Cidade do Recife. Rio de Janeiro, Livraria José Olympio Editora, 1942.P. 27.

195 "In Recife, where he arrived December 7, 1809, Koster, aided by letters of introduction, soon adjusted himself to the tempo of Brazilian life. For the next ten months, except for attendance at festivals in Olinda and a residence at Poça da Panella, he remained in Recife. In mid-October, 1810, he left Recife on a northerly trip which consumed the next four months. By horseback, he traveled to Goiana, Paraiba, Natal, Açu, Santa Luzia, Aracati and Fortaleza, then back to Recife. This overland trek acquainted the eager foreigner with many facts of life in the Sertão, including its Indians and those successive scourges of nature, drought and flood. The hospitality of strange men and the wonders of even stranger nature Koster regularly recorded in his journal, there by amassing materials which later added color and fresh detail to his account of a region about which Englishmen would read for the first time. GARDNER, Harvey. Apresentação. In: Travels in Brazil. Southern Illinois University Press, 1966, EUA.https://www.questia.com/read/14759866/travels-in-brazil. 
Para seu tradutor, Câmara Cascudo, Koster não é um viajante ${ }^{196}$, nem ele mesmo teve a intenção de publicar alguma coisa, como nos conta em seu Prefácio:

Não tive jamais a intenção, durante minha residência no Brasil, de publicar cousa alguma do que vira e ouvira nesse país. Não foi senão ${ }^{197}$ depois do meu regresso que me encorajaram a reunir todos os detalhes que pudesse ${ }^{198}$ comunicar. ${ }^{199}$

Ainda nos conta sobre seu processo de escrita, sua facilidade de percepção quanto ao mundo falado em língua portuguesa e ao provável leitor dirige um pedido para que pouca importância seja dada ao livro, sobretudo por sua natureza:

Espero que o leitor queira por bem escuzar os defeitos que possa descobrir neste livro quando saiba que não fiz observações seguidas no Brasil com pensamento de publicar os resultados. Acrescento que a língua portuguesa me é mais familiar que a do meu país. O leitor

196 Henry Koster não é um viajante, caçando anedotas e filmando o pitoresco nem um naturalista, tendo a investigação anteriormente programada. Não há nele a missão unilateral de estudar um aspecto ou fixar pormenores. Não o subsidia Museu ou Instituto. É uma curiosidade ampla e livre, sem compasso, sem barras, nem limites. É uma criatura humana, vivendo humaníssima e logicamente. Não teve a obrigação de regressar à Pátria, com bichos, folhas e relatórios. Independe de qualquer autoridade uma sua conclusão. CASCUDO, Luís da Câmara. Prefácio do Tradutor. In: KOSTER, Henry: Viagens ao Nordeste do Brasil. São Paulo, Companhia Editora Nacional, 1942.

197“sinão"

198 "podesse"

199 KOSTER, Henry. Prefácio do Autor. In: Viagens ao Nordeste do Brasil. Tradução e notas de Luiz da Câmara Cascudo. 2a ed. São Paulo, Companhia Editora Nacional, 1942. 
Câmara Cascudo nos conta que, no seu Prefácio de Tradutor ${ }^{201}$, Koster afirma o que sabe, ouve ou repara e que tomava notas sentado na porta da casa grande, pisando $^{202}$ o massapê do canavial, cochilando no embalo da rede, sacudido no chôto ${ }^{203}$ do cavalo "tungão"204, mastigando léguas-de-beiço ${ }^{205}$.

Cascudo compara o fato de que Koster sofisticava o olhar da percepção da paisagem com o experimentar o lugar pela presença, não pela passagem, a exemplo de outros cronistas que também observaram lugares, porém seguiram adiante, como Spix, Martius, Wied, Neuwied, Lubbock, Mawe e Saint Hilaire.

Ainda Cascudo nos informa que o livro foi escrito entre 1815 e 1816, momento em que Koster se encontrava "mergulhado na [brasiliana] de Robert Southey”, poeta inglês possuidor de biblioteca de 14.000 volumes. Pelo título Travels in

200 "England is my country, but my native soil is Portugal"; "[...] although I was acquainted, still I had not since early youth been in a country where it was generally spoken." E [...] this idiom of a foreign language is perhaps more familiar to me than that on my own". Idem

201 "Travels in Brazil has been twice translated in Brazil, by Antonio C. A. Pimentel who unfortunately worked from a French text at turn of century, and recently (1941) by the able Luiz da Camara Cascudo Henry Koster's life, made memorable by his one book, was a short one." idem

"Luiz da Camara Cascudo,who translated the work in 1941 for his fellow Brazilians under the title Viage ns ao Nordeste doBrasil, asserts that Koster returned to Pernambuco in the autumn of 1816, witnessed th erevolution in Recife on March 6, 1817, and died in his adopted transatlantic homeland, possiblyearly in 1820, age unknown, but young in heart." idem

202 “pizando”. Brasiliana, vol. 221. Edição de 1942.

203 "chouto": trote miúdo de montaria

204 "lerdo"

205 Antiga expressão nordestina para medida. 
Brazil, porém, ele entendia como ('tradução fiel' as Viagens ao Nordeste do Brasil, porque o Brasil de Koster é Pernambuco e as províncias setentrionais) ${ }^{206}$

Morou e viu Pernambuco. Paraíba, Natal, Aracatí, Fortaleza, São Luís do Maranhão, Alcantara. E Sertão. Sertão legitimo, com seca, léguas sem fim, gado morrendo, solidão, resistência, heroísmo, primitividade. ${ }^{207}$

Publicada em Londres em 1816, a narrativa obteve grande repercussão na Europa, por informar sobre as grandezas ali descritas, como uma representação do Brasil, sob o olhar de um estrangeiro comerciante ${ }^{208}$ produzindo, à distância, uma obra que busca recuperar, pelas memórias, em língua estrangeira, o exercício do contar sobre, ao decifrar e ao mesmo tempo traduzir a natureza, a gente e as relações sociais e econômicas de um país que se constituía aos poucos, o Brasil, por meio do olhar curioso

206 Cascudo, p.10, 1941.

207 Câmara Cascudo, p.10, 1941 "In making use of the word Brazil, it must be understood that I mean to denote that portion of the country which I have had opportunities of seeing." (Koster)

208

Um véu de mistério parece encobrir as reais motivações de Henry Koster nas viagens que empreendeu ao nordeste do Brasil e que lhe serviam de inspiração para o livro que publicou, em 1816, sob o título de Travels in Brazil. "Embora se diga comerciante, raramente encontram-se motivações de ordem econômica para as suas viagens", assinala o professor Harvey Gardner, na apresentação a Travels in Brazil (Southern Illinois Univesity Press, 1966, EUA.) Luís da Câmara Cascudo, em sua admirável tradução anotada das Travels - em que se permitiu corrigir o viajante inglês, reintitulando-as Viagens ao Nordeste do Brasil - observa que Koster não é rico, mas também "não aparece dependendo de ganhar dinheiro para viver". Cascudo tentou em vão afastar a cortina de fumaça que obscurece a biografia de Koster, culminado essa busca no capítulo "Biografia impossível" que integra seu "Prefácio de Tradutor" à sua tradução da referida obra. PATRIOTA, Nelson. Prefácio. In: Koster, Henry, Como melhorar a Escravidão. Natal: EDUFRN, 2003. 
de um viajante que, na sua escrita, afirmou o que sabe", "ouviu" ou "reparou" e que veio viver Pernambuco para se defender da tuberculose"209.

Câmara Cascudo nos informa que Koster viajou de Liverpool pelo "Lucy", a 2 de novembro de 1809 e chega ao Recife em 7 de dezembro porque amigos e família recomendaram mudança de clima, sendo que "um íntimo elogiara calorosamente os ares pernambucanos." Relata em seu prefácio que Koster viera viver em Pernambuco "se defendendo da tuberculose". Comenta também que, possivelmente era filho de negociantes ingleses estabelecidos em Portugal, país onde nasceu, mas que teria deixado ainda jovem para estabelecer-se na Inglaterra ${ }^{210}$.

Entre outubro de 1810 e abril de 1811, viaja por Goiana, Igarassú, Mamanguape, Cunhaú até chegar a Fortaleza, “em tempo de seca, varando agreste, praia, catinga, taboleiro e sertão", de onde parte para Aracatí, Santa Luzia do Mossoró, Areais, Cajuais, Aracatí até alcançar um barco para São Luís do Maranhão, de onde veleja para a Inglaterra a 8 de abril e, devido ao clima, retorna ao Recife, em 27 de dezembro de 1811:

Viaja anotando tudo, os homens, as raças, as paisagens, os animais bravos, a natureza dos terrenos atravessados, crenças, tarefas agrícolas produtos, pecuária, almas-do-outro- mundo, costumes, indumentária, alimentos... ${ }^{211}$

Observando-se o título em língua estrangeira e a opção realizada por Luís da Câmara Cascudo em nomear a parte como um todo, o "Brasil" de Henry Koster substituído por "Nordeste", razões que o folclorista explica no prefácio como "o Brasil

209 "Filho do comerciante inglês de Liverpool, John Theodore Koster, Henry Koster nasceu em Lisboa, Portugal. Não se sabe ao certo a data do seu nascimento, mas ao chegar no Recife, no dia 7 de setembro de 1809, consta que tivesse 25 anos de idade.Considerado um dos mais importantes cronistas sobre o Nordeste brasileiro, Koster viajou para o Brasil em busca de um clima tropical para curar uma tuberculose". GASPAR, Lúcia. Henry Koster. Fundação Joaquim Nabuco, Recife. Disponível em: <http://basilio.fundaj.gov.br/pesquisaescolar/>. Acesso em: 09 de agosto de 2015.

210 KOSTER, H: op. cit., p. 11.3

211 Cascudo, p. 12, 1941. 
de Koster é substituído por Pernambuco e pelas provinciais setentrionais". Cascudo já coloca a condição de "credibilidade" do texto, graças ao "quanto viu e registrou fielmente.",212

No Artigo intitulado Imagens da Condição Feminina em "Travels in Brazil", de Henry Koster, Izabel Andrade Marson ${ }^{213}$, concebe a obra como "um relato de um viajante que se refugiava em Pernambuco por motivos de saúde", fornecendonos a divisão em duas partes: um diário das estadias de Koster no Brasil e reflexões sobre a sociedade das Capitanias do norte, diário esse que relata as duas passagens do autor pela região: na primeira, entre dezembro de 1809 a abril de 1811, quando percorreu as principais vilas da zona da Mata de Pernambuco, Paraíba, Rio Grande; a rota que ligava as fazendas de gado do Sertão Cearense ao porto de Recife e as vilas do litoral do Ceará e o porto São Luís do Maranhão; na segunda, entre dezembro de 1811 e 1815, quando se estabeleceu em Pernambuco, primeiramente como senhor e depois como lavrador de engenho. Arrenda o engenho no Jaguaribe, "com escravaria, canaviais, vizinhos ${ }^{214}$, superstições, vaidades velhas, bondade simples, um mundo novo em que o inglês mergulha, gostosamente" e posteriormente para a Ilha de Itamaracá, onde durante duas semanas dorme na sacristia de uma Capela, sacristia malassombrada e cheia de morcegos, corujas e bacuraus de grandes olhos luminosos, fixando-se no Toque, defronte da Povoação da Gambôa, plantada num outeiro":

Aí viveu vida de plantador de cana, deletrando com os padres, visitando os arredores, vendo o Mamulendo, conversando com os negros, dormindo de rede, bebendo cachaça para não constipar quando viajava debaixo da chuva, assitindo aos crepúsculos, fazendo

212 “Koster, pequeno proprietário, não tem imaginação." Considerado como o "exato" Koster, segundo outro escritor inglês, Richard Burton. Cascudo, ainda: "Em parte alguma do Travels in Brazil haverá material para um enredo cinematográfico. Nada descreve além do que, em alta percentagem, ainda vemos, ou até pouco tempo víamos, nas regiões em que vivera o registrador. O exato Koster é digno do título".

213 Professora do Departamento de História IFCH - UNICAMP.

www.bibliotecadigital.unicamp.br/document/?down=50925. Acesso em 20 de agosto de 2015.

214 'visinhos”, como registro. Brasiliana, vol. 221.Edição de 1942. 
sono perto das fogueiras ou vendo o luar, um luar tão claro que se podia dispensar a lâmpada para ler. ${ }^{215}$

Cascudo nos informa que, no começo do ano de 1815 , precisa retornar à Inglaterra, pois "sua presença é exigida" e Koster acredita numa despedida final, momento em que está "quase um senhor de engenho":

Com pouco tempo só poderá amar aquele ambiente, com aqueles hábitos, gestos, ordens e alegrias primitivas, desde o Entrudo com lata d'água até a festa de Nossa Senhora da Conceição em que foi

[noiteiro]. Parte com saudade derramada nas cousas vivas e mortas. $^{216}$

O livro reuniu as anotações de Koster complementadas com uma pesquisa feita na biblioteca do historiador Robert Southey e devidamente organizadas em capítulos. A segunda parte da obra é constituída por seis capítulos conclusivos e um Apêndice. Neles Koster apresentou reflexões sobre a agricultura, a sociedade e a escravidão.

Enquanto os ingleses editaram as Viagens em 1816 e 1817, norteamericanos em 1817, franceses em 1818 e em 1846 e alemães em 1817 e 1831, a primeira edição brasileira foi finalizada em junho de 1899. Publicada pela Revista do Instituto Arqueológico Pernambucano, foi traduzida, a partir da versão francesa de M. A. Jay, edição de 1846, por Antonio C.A. Pimental e somente publicada trinta e cinco anos depois, na Revista do Instituto, no 51, e distribuída no Recife, em 1933, conforme nos informa Câmara Cascudo.

215 Câmara Cascudo, p. 14, 1941.

216 Idem, p. 15, 1941. 
Ninguém fixou a sociedade pernambucana, a sociedade dos fazendeiros do Nordeste, a psicologia do senhor do engenho, o mundo escravo, como Henry Koster. Fixou porque viveu intensamente essa existência que conhecemos descrita por mãos contemporânea ou olhos atuais.

E ainda:

É esse Henry Koster que sonhei restituir à circulação intelectual do Brasil, no seu livro claro, ensopado no leite da ternura humana. ${ }^{217}$

Imaginação e arte por meio da "expressão" e "intuição" integram a interpretação de textos que dialogam ideologicamente com outros. Procurar decifrar esse contexto por meio do texto é de certa forma realizar a tradução de um tempo que alcançamos graças às teias discursivas, interpretações que flutuam entre o historicismo aberto, um convite ao debate entre o historiar e o memoriar. .

Se, por um lado 'literatura não é documento ${ }^{218}$, por outro, entre a literatura e outras disciplinas não se pode falar em fronteiras, sobretudo quando tratamos sobre gêneros literários. ${ }^{219}$ 'Há que se pensar nos fatos ${ }^{\text {,20 }}$, nos discursos ${ }^{221} \mathrm{e}$

217 Idem, p. 22 e 27.

218 "Ilustrar com arte. Emocionar ou enternecer o espectador, para provar que a literatura é qualquer coisa de superior, que nos eleva e transcende. [...] A literatura é aqui mais um dos nossos valores, como os sertões e os casarios que o escritor pisou: manifestações sublimes da Nossa Natureza e Cultura." CESAR, Ana Cristina. Literatura não é Documento. Crítica e Tradução. São Paulo: Instituto Moreira Salles / Editora Ática, 1999. P. 52.

219 CARPEAUX, Otto Maria. Introdução. In: História da Literatura Ocidental. Rio de Janeiro, Alhambra, 1978 .Volume 1.p.15 a 36.

220 "A poesia existe nos fatos. Os casebres de açafrão e de ocre nos verdes da Favela, sob o azul cabralino, são fatos estéticos." ANDRADE, Oswald. Manifesto da Poesia Pau-Brasil. In: TELES, Gilberto Mendonça. Vanguarda europeia e modernismo brasileiro: apresentação e crítica dos principais manifestos vanguardistas. Petrópolis, Vozes, 1976.3ª Ed.

221 (Desde o século XIX, a crítica que se ocupa da poesia atribuída a Gregório de Matos e de outros discursos coloniais penso, por exemplo, em Anchieta, Nóbrega, Bento Teixeira, Vieira, Manuel Botelho de Oliveira, Cláudio Manuel da Costa, Basílio da Gama, etc.) costuma ignorar e eliminar 
no valor social ${ }^{222}$ que arte e literatura comportam diálogos e debates, sobretudo quando refletimos sobre questões como territórios da leitura e da escrita e a relevância de se recuperar construções literárias com forma e expressão, sobretudo em se tratando de estudos coloniais.

Na condição de pesquisa, interessam-nos esses vestígios, as ruínas sob escombros, revendo o paradigma da leitura e reflexão, traduzindo o contexto submerso, a partir de fontes de informação, as obras que inventariam e documentam um rol de invenções e de categorizações que permitem o diálogo sobre a terra e as gentes do Brasil, sobretudo quanto ao período colonial, não como um espaço imaginário, inventado ou historiograficamente constituído, mas o quanto diários, crônicas, histórias das muitas viagens, nos convocam a aproximarmo-nos ou a distanciarmo-nos de textos e contextos, diante de obras produzidas que, ou naufragaram nas mãos de alguns críticos literários ou foram fossilizadas como "documento" por parte da historiagrafia. Interessanos pensar sobre o quanto tais obras permanecem desconhecidas por leitores e como

sistematicamente suas categorias, substituindo-as por outras, que universalizam valores interessados do presente dos intérpretes". HANSEN, João Adolfo. Letras Coloniais e Historiografia Literária. Rio de Janeiro: UERJ, 2015.

222 "Cette question de la valeur sociale de la littérature a largement été investie par la sociologie de l'art. Comme le rappelle notamment Pierre Bourdieu, bénéficiant d'un statut sacré (Bourdieu, 1998), la littérature et l'art correspondent à des 'jeux sociaux' les plus entourés de prestiges et de mystères (Id., 1988). En tant qu'objet 'sacré' et 'consacré' (Id, 1988) fortement chargé d'une valeur sociale, la littératue peut donc constituer un élément particulièrment intéressant à utiliser dans d'autres champs sociaux. Cette instrumentalisation sociale consiste alors à utiliser cet 'objet de croyance' (Id. 1988), à en exploiter le potentiel dans le cadre d' un projet social particulier n'ayant pas pour ambition première la création artistique, mais par exemple la cohésion sociale, la construction d'une identité territoriale spécifique por les cas sur lesquels se focalisent ce premier chapitre. L'instrumentalisation de la littérature par le politique consiste donc alors à faire appel au sacré, au symbolique, au pouvoir social de la littérature et de l' écrivain et à les mettre au service d'un projet de territoire." MOLINA, Géraldine. La question de la valeur et de l'utilisation sociales de la littérature: la littérature un embrayeur du 'vivre-ensemble', 'du faire société en ville? In: Les faiseurs de ville et la littérature: lumières sur star-system contemporain et sés discours publics. Des usages de la littérature au service de l'action des grands architectes-urbanistes. Tome 1. Toulouse: L’Université de Toulouse II - Le Mirail, 2010. 
prováveis consumidores recepcionam sua leitura, percebem os contextos, observam o quanto a interdisciplinaridade da interpretação funciona como uma possibilidade de acesso, uma vez que estamos diante de um gênero híbrido. ${ }^{223}$

Não significa aqui estudar a cronologia das obras, como nos ensina Carpeaux, mas observar o quanto o texto, em tempos diversos, recepciona ou não a evolução de um meio de expressão de ideologias diferentes, o quanto as crônicas produzidas sobre o Brasil em séculos anteriores dialeticamente se comunicam com a leitura realizada por leitores contemporâneos.

A contribuição de Croce para Carpeaux reside no fato de realizar uma crítica que abandona a pretensão positivista da introdução do método exato, ou seja, dissecar o texto nos moldes das ciências naturais, mas pensar o texto segundo uma "ciência de espírito", principalmente na historiografia.

Carpeaux nos propõe estudar a literatura enquanto expressão estilística do espírito objetivo, como reflexo das situações sociais, alcançando a metafísica por meio da sociologia do saber para se perceber o sentido social de formação de civilização, como substituto do rol de eventos históricos que procuram determinar os contextos nos quais textos são produzidos.

Contudo, há que se relacionarem textos e contextos nos processos de leitura. Nossa perspectiva parte de uma condição de colônia, uma vez que nossa formação, nossa ancestralidade, não participou da universalidade das grandes literaturas, como a grega, a romana, a russa, a italiana, a espanhola, a francesa, a inglesa, a alemã, a escandinava, a portuguesa, a holandesa, a polonesa, a provençal ou a catalã, em função do tempo, do contato, da comunicação com outros povos. Fomos encontrados e nos constituímos, ao passo que as outras culturas participaram da circulação com outros povos e mundos.

223 Não se constrói a "ficção" de forma diferente da "realidade". O historiador que, a partir de documentos escritos, ou o juiz que, apoiando-se em testemunhas reais, reconstituem uns e outros, os acontecimentos não procedem em princípio diferentemente do leitor”. (p.102). TODOROV, Tzvetan. $A$ Leitura como Construção. In: Os Gêneros do Discurso. São Paulo, Eduções 70, 1978. 


\section{A PROSOPOPEIA DA VIAGEM POR LETRAS COLONIAIS}

WHY STUDY LITERATURE?

Literature is news that STAYS news.

Ezra Pound ${ }^{224}$

Decidimos, inicialmente, investigar o campo das letras coloniais, entre a épica e a temática da viagem, com o objetivo de se repensar os estudos literários necessários ao resgate de concepção de mundo, por meio de escritos não recepcionados ou arrolados como canônicos pela crítica, com base nas seguintes proposições, perenes durante a pesquisa acadêmica:

Por que estudar narrativas coloniais ao invés de realizar uma escolha acadêmica pragmática como, por exemplo, investir num MBA voltado para uma área cujo mercado absorva prontamente nossa pesquisa, com retorno líquido e certo, atento às grandes questões da modernidade e que nos chancele uma empregabilidade imediata? ${ }^{225}$

Ou ainda, há espaço e interesse hoje para se realizar a leitura de um texto épico ou de uma narrativa descritiva? Como podemos recepcionar, no projeto pedagógico, textos produzidos em outros contextos?

224 POUND, Ezra. ABC of Reading. London:.Faber and Faber, 1991.P. 29.

225 Noam Chomsky em seu artigo Occupy the Future, publicado no New York Times em 2011: Segundo o Autor, o capitalismo vive não apenas uma crise cíclica de "destruição criadora", mas um momento de declínio geral que ameaça até mesmo a sobrevivência da espécie. Nesse momento, opõe-se uma plutonomia, como designa a economia conspícua de produtos de luxo em nichos globais, a um proletariado cada vez mais precarizado. CARNEIRO, Henrique Soares. Occupy: movimentos de protestos que tomaram as ruas. São Paulo: Carta Maior / Boitempo Editorial, 2012. 
E como despertar nos leitores o interesse em ler quando constatamos cada vez mais uma ausência da práxis de leitura, dentro e fora dos muros da escola?

Como mediar condições de leitura de textos clássicos, articular linguagens e condicionantes necessárias à percepção dos discursos presentes quando constatamos, nos dias atuais, a presença de um leitor versado mais na oralidade do que habilitado a compreender na escrita questões difusas, visto que a leitura das letras coloniais demanda um preparo mais sofisticado do olhar e do interpretar temas e questões circulantes há séculos?

«O verdadeiro esforço de reflexão teórica, não está em interpretar as coisas, mas em interpretar a interpretação».

Michel de Montaigne 226

Refletir sobre o conhecimento dessas narrativas produzidas, independentemente de serem rotuladas por escolas literárias, promove o enriquecimento da formação geral pelo campo dos saberes adquiridos, das práticas necessárias para a formação da cidadania, bem como compõem a apropriação de textos básicos que, pela diversidade de questões, ampliam a possibilidade, pela leitura, de uma base de conhecimento voltado para a territorialidade, transdisciplinaridade, multiculturalismo, bem como pela aquisição de saberes elencados por escritores que pensaram a pasta da educação e da cultura como agenda necessária para a transformação da sociedade brasileira. Nomes como Milton Santos, Mário de Andrade, Anísio Teixeira, Paulo Freire e Darcy Ribeiro são necessários ao debate.

Outra proposição substancial precisa ser levantada: pesquisar narrativas coloniais que traduzem aspectos da região nordeste não deve ser visto como um estudo regional apenas, mas unificado a toda uma dinâmica de composição do território: a paisagem colonial entre o mar e o sertão, assim como o tecido social que aos poucos se

${ }^{226}$ MONTAIGNE, Michel de. Ensaios. São Paulo: Abril Cultural, 1972. 
constituía, graças ao projeto de divisão da terra e das categorias sociais, entre a casa grande e a senzala, fruto do projeto pensado sobre capitanias hereditárias, monocultura do açúcar e escravidão.

Vale lembrar que a maior cidade do Brasil, é também a mais nordestina e que ensinamos, todos os dias, os filhos de muitas famílias que saíram de suas terras pelo mito da mudança de vida.

Cabe a todos nós pensarmos que, a composição desse mundo lido, interpretado como conquista, descoberta, ou encontro traduz não somente a viagem, mas a epopeia do retirante, do desterrado que chega a São Paulo e que se concentra, sobretudo, na periferia da grande cidade, em busca da realização de sonhos de uma vida digna, do pão e da água de cada dia, como assim lhes assegura a Constituição Federal: o direito à moradia, à saúde e à escola, mas que, muitas vezes, alcança somente a condição da favela, da subnutrição e do analfabetismo funcional.

Não cabe aqui pensarmos no pressuposto regional nem atemporal das narrativas investigadas para a composição da tese, mas propor a leitura das obras de forma sincrônica com outras em circulação, como Os Lusíadas, a Eneida, tanto pelo mundo épico, bem como por cronistas e viajantes, num constante diálogo entre textos e contextos, observando-se a condição de imitatio, fruto do modelo aristotélico de produção e circulação de ideias.

Codificar os gêneros textuais ${ }^{227}$ em circulação e decodificar os mundos épico e narrados sob o signo da viagem são estratégias que sugerem uma possibilidade de se interpretar ou de traduzir esses mundos pelas letras, graças à sincronia porque dialogam com outros textos literários, canônicos ou não, ou à diacronia, porque transitam como fontes sob o signo da língua e da cultura .

227 Segundo Maria Elaine Andreotti, a Literatura de Viagem sugere uma classificação generalista, uma vez que abarca "diversas formas estabelecidas, como a epopeia, a epístola, a crônica, o diário (de bordo ou íntimo), o romance, o guia.” ANDREOTTI, Maria Elaine. A selva europeia e o paraíso tupinambá: tópicas sobre mundos na História de uma Viagem ao Brasil de Jean de Léry. Dissertação de mestrado. Área de Literatura Brasileira, USP, 2013. 
São, sem dúvida, pressupostos para a formação de um corpus literário barroco nacional, visto que temos em mãos poéticas luso-brasileiras, de um lado e, por outro, um gênero de fronteira que transita, como um pêndulo, entre a história e a literatura.

Cabe aqui ressaltar que um programa de pós-graduação do Sudeste deve incluir essa temática, como justificativa de investigação, porque questões de ordem da terra e da gente do Brasil são instigantes ao debate, ao realizarmos uma leitura a qual parte de Pernambuco e que, todavia, não há que se pensar, exclusivamente, segundo uma perspectiva regional, restritiva; caso contrário, realizaríamos uma leitura anacrônica, a exemplo da crítica que leu as obras mediante essa ferramenta de interpretação excludente, não dialética, não inclusiva.

A medida que pensamos o estudo das letras e da cultura como base para a integralidade de um contexto em formação, como herança das primeiras letras em circulação no território, ainda que não belas para boa parte da crítica, nos damos conta da necessidade de rever o estudo das práticas de representação de toda uma narrativa que precisa ser percebida mediante a prosopopeia da viagem.

Entre as divindades marinhas reunidas no Porto do Recife, ao ouvirem Proteu cantar um passado de glória da família dos donatários e as muitas vozes testemunhadas pelo viajante Koster entre o mar e o sertão, nos damos conta da paisagem e de sua gente à medida que lemos e que somos conduzidos a traçar essa cartografia pela leitura.

A resposta para todas essas indagações se encontra na dialética da modernidade ${ }^{228}$, a qual precisa conversar com esses espaços, sob a perspectiva da

228 "Alterar o significado do tempo e do espaço, da história e da memória, do ser e do devir leva consigo implicações inesperadas e surpreendentes. O Velho Mundo começou a existir quando os navegantes descobriram e conquistaram o Novo Mundo. O Ocidente somente começou a existir quando os viajantes, comerciantes, traficantes, missionários, conquistadores e outros descobriram e conquistaram o Oriente." IANNI, Octavio. Enigmas da Modernidade-Mundo. Rio de Janeiro, Civilização Brasileira, 2000. 
formação de um povo e das primeiras letras que daqui partiram para narrar o outro, fazendo uso do gênero textual vigente à época em que foi produzido.

Embarcamos, pois, na leitura do texto, para se perceber o contexto em que se coloca a linguagem e a estética literária, ainda que não genuinamente pensada como literatura brasileira, mas em diálogo com outras, a exemplo d' Os Lusíadas.

Gilberto Freyre, no Manifesto Regionalista de 1926, nos auxilia a rever que Pernambuco se coloca como parte integrante de uma nacionalidade, a qual ganha sentido de "organicamente brasileira" e por que não americana.

Apresentado por Freyre no Primeiro Congresso Brasileiro de Regionalismo, realizado em fevereiro de 1926, no Recife, subdividia-se em capítulos que reivindicavam uma condição de se olhar para o momento estético de forma integral.

No seu capítulo XXI, Freyre nos propõe a seguinte pergunta: onde estão os poetas, os romancistas, os contistas? Onde estão os pintores, os fotógrafos, os compositores? E convidanos a repensar a condição do Brasil sob o ponto da cultura.

O Nordeste tem o direito de considerar-se uma região que já grandemente contribuiu para dar à cultura ou à civilização brasileira autenticidade e originalidade e não apenas doçura ou tempero. Com

Duarte Coelho madrugaram na Nova Lusitânia valores europeus, asiáticos, africanos que só depois se estenderam a outras regiões da América Portuguesa. Durante a ocupação holandesa, outros valores aqui surgiram ou foram aqui recriados para benefício do Brasil

inteiro. 229

Nesse sentido, olhar para os estudos como uma condição regional não é o procedimento adequado, uma vez que a interdisciplinaridade do caráter "Nordeste" se

229 DIMAS, Antônio. Comentário sobre o Manifesto Regionalista. FREYRE, Gilberto. Manisfesto Regionalista.7.ed. Recife: FUNDAJ, Ed. Massangana, 1996.p.47-75. 
articula com o "Brasileiro"230, uma realidade que a expressão Nordeste define sem que a pesquisa científica a tenha explorado até hoje, sob o critério regional da paisagem. Com Duarte Coelho, "madrugaram na Nova Lusitânia valores europeus." Não havia, portanto, como se pensar na condição de nacional, até porque o país, aos poucos, se constituía.

Melhor pensarmos na circulação das letras atribuídas a Bento Teixeira, como narrativa épica, como descrição cartográfica da prosopopeia da viagem, e afastar uma predisposição a se pensar o texto diacronicamente morto pelo gênero, sincronicamente dialético com o epistema de ideias, como a diversidade, ${ }^{231}$ a ser compartilhada numa rede de espaços e de saberes $^{232}$, pois há uma concepção de mundo que se coloca.

230 "O Congresso Regionalista do Recife queria mais alguma coisa (...): caminhava para a vida. Como tudo que é de Gilberto Freyre, a vida comandava neste seu congresso que para muita gente não passou de desfrute. Todo o seu corpo de ideias de Casa Grande já se esboçava ali. A terra e a gente não como temas, mas como personagens do drama. Pintor, poeta e músico no corpo expedicionário do cientista. [...] no plano artístico é uma sondagem na alma do povo, nas fontes do folclore, no que há de grande e vigoroso na alma popular. E daria um Cícero Dias na pintura, um Luís Jardim no conto, e na culinária uma preta Eva. No plano das ideias, daria mais tarde o seu grande livro Nordeste, de uma força lírica, de um poder de síntese que vai da alma ao corpo, que atravessa zonas misteriosas e escuras e os grandes dias claros. Em poesia seria a Evocação do Recife, de Manuel Bandeira". E: "Nesse sentido o regionalismo do Congresso do Recife merecia que se propagasse por todo o Brasil, porque é essencialmente revelador e vitalizador do caráter brasileiro e da personalidade humana". RÊGO, José Lins do. "Prefácio". IN: Freyre, Gilberto. Região e Tradição. Rio de Janeiro: Gráfica Record Editora, 1968, p. 33.

231 Boaventura de Sousa Santos nos sugere o diálogo de hermenêutica diatópica: "trata-se de uma prática de interpretação e de tradução entre culturas, do diálogo entre culturas, por intermédio da qual se amplia a consciência da incompletude de cada cultura envolvida no diálogo e se cria a disponibilidade para a construção de formas híbridas de dignidade humana mais ricas e mais amplamente partilhadas." Introdução: para ampliar o cânone do reconhecimento, da diferença e da igualdade". In: SANTOS, Boaventura de Sousa. Reconhecer para Libertar. Os Caminhos do Cosmopolitismo Multicultural. Rio de Janeiro: Editora Civilização Brasileira, 2003.P.25-66.

232 Para Pierre Lévy," o "eu" não pensa ou é inteligente sozinho, mas se torna completo com o grupo cultural do qual é membro, com sua língua e toda uma herança de métodos e tecnologias intelectuais, 
Uma questão substancial precisa ser levantada: a condição de representação do verossímil ${ }^{233}$, por meio das belas letras, que traduzem o mundo de seu tempo em que foram produzidas, renascentista, uma poética escrita à moda de Virgílio, Lucano, Ariosto ou Dante e que Bento Teixeira, enunciando a mundaneidade de seu tempo, por meio de versos e rimas, se coloca como um poeta artífice, seguindo um costume e promovendo o discurso à moda de seu tempo, a um destinatário oculto, sob o signo da alteridade, de um pernambucano sob a condição atlântica.

Cabe aqui pensarmos nas ruínas, nos pressupostos enunciativos do gênero em circulação, a composição e combinação do vernáculo, a condição textual que atesta uma sincronia entre categorias de textos em circulação que Ele, autor, conhecia, pela leitura de textos e do mundo ao qual pertencia, por sua condição de professor, perseguido como judeu, em terras tropicais, um universo que se constituía por aqui e se desconstituía em Portugal pela perda de D. Sebastião. Pernambuco é inserido nesse contexto.

Há que se considerar, contudo, conceitos sugeridos por Hansen, no sentido de se conceber a leitura do poema, a partir de um intervalo semântico, com base no gênero em circulação, como n’Os Lusíadas, uma espécie de variação engenhosa do

dentre as quais o uso da escrita." In:. SALVATIERRA, Eliany. Ecossistema Comunicativo e Cognitivo. São Paulo: USP, Núcleo de Comunicação e Educação da Universidade de São Paulo: 2008. P.01-07.

233 O Professor Brandão reflete sobre o conceito de verossimilhança, como pertencente tanto à concepção poética como retórica, com base na Poética enunciada por Aristóteles, para distingui-lo entre os campos da história e da poesia: "a obra do poeta não consiste em contar o que aconteceu, mas sim coisas quais podiam acontecer, possíveis no ponto de vista da verossimilhança ou da necessidade.” [...] "Não é em metrificar ou não que diferem o historiador e o poeta; a obra de Heródoto podia ser metrificada; não seria menos uma história com o metro do que sem ele; a diferença está em que um narra acontecimentos e o outro, fatos quais podiam acontecer. Por isso, a Poesia encerra mais filosofia e elevação do que a História; aquela enuncia verdades gerais; esta relata fatos particulares" (Poética, IX) In: Aristóteles, Horácio e Longino. A Poética Clássica. São Paulo: Editora Cultrix, 2011.p.01 -11. 
mundo predicado graças à teoria da recepção ${ }^{234}$, a fim de se perceber a apropriação da leitura por um leitor que não mais permanece na condição de anonimato, de público.

Ao se aproximar de elementos, dos signos de interpretação históricoliterário, a esse leitor lhe é facultado o convite, ao embarque num mundo que não pretende apenas historicizar a aventura, mas conversar, proporcionando dialeticamente o conhecimento pela transposição no plano das vivências, dos costumes e das práticas coloniais vigentes, uma vez que o Atlântico não se colocava mais como um divisor do mundo, mas o caminho para o conhecimento do outro. Aí reside a condição do deslocamento, mais do que físico.

Essa questão é permanente quando analisamos a dinâmica de circulação de povos no mundo, à procura de terra firme, segura, como espaço. Hoje, presenciamos o Mediterrâneo tornar-se um cemitério de náufragos, desesperados, a cruzar o mundo sob os olhos de países que historicamente vilipendiaram e usurparam secularmente, direta ou indiretamente, por ação ou omissão, suas terras: vidas, espaço, riquezas, cultura e, sobretudo, dignidade humana, um crime internacional de ordem difusa, contra os direitos civis e, sem dúvida, uma afronta à proteção supranacional dos direitos humanos.

E como o Brasil é representado nessa narrativa? Como se processa o retrato dos descendentes de Duarte Coelho, inseridos graças ao texto narrativo, ao contexto épico de Alcácer Quibir e Lisboa, universalizando dinâmicas de tempo e de espaço por meio daquilo que se conta, em rima e versos, como prosa histórica? Em qual outro contexto histórico, escrito a partir do Brasil, há uma transposição de personagens transpostos, segundo o paradigma do outro?

Se o poema não pertence à literatura brasileira, também não pertence à literatura portuguesa. Podemos pensá-lo apenas como um poema histórico? Ao

234 "Para a análise da experiência do leitor ou da sociedade de leitores de um tempo histórico determinado, necessita-se diferenciar, colocar e estabelecer a comunicação entre os dois lados da relação texto e leitor. Ou seja, entre o efeito, como momento condicionado pelo texto, e a recepção, como o momento condicionado pelo destinatário, para a concretização do sentido como duplo horizonte - o interno ao literário, implicado pela obra." JAUSS, Hans Robert. A Estética da Recepção. In: A Literatura e o Leitor. Textos de Estética da Recepção. 2.ed. São Paulo: Paz e Terra, 2001. P. 43-61. 
promovermos a leitura de Prosopopeia sob o estatuto de narrativa épica, históricoliterária, como mediar essa leitura para um leitor contemporâneo?

Bosi nos fala sobre textos que demandam vocação multidisciplinar. Podemos perceber a Prosopopeia como um poema épico que comunica saberes híbridos, por se tratar de um cantar que articula muitas grandezas sob um gênero vigente e Bento Teixeira, como o sujeito cuja composição poética versa a comunicação entre mundos, ao compor sua poética sob a estética do arrolar aventuras, personagens míticos e históricos, sugerindo uma grande viagem pela leitura, por letras cuja estética e poética nos permite a perceber espaço e tempo inventados e ilustrados.

Essas questões nos levam a perceber como pensar a leitura de um texto distante de um leitor contemporâneo e que, se facilitado por um uma adaptação, perderá grande valor estético.

Não cabe aqui pensarmos se a Prosopopeia pode ser percebida como o texto fundacional do Brasil até porque essa investigação não pretende enveredar por essa questão, uma vez que não há que se falar em literatura brasileira nesse tempo, mas em circulação de obras apócrifas ou de criação pluriautoral, práticas literárias em trânsito entre culturas, uma dinâmica de encontro entre povos e universos diferentes, como línguas, costumes, tradições e expressões, motivado pelo advento das grandes viagens e conquistas.

Durante cerca de um século depois da atividade poética de Anchieta, quase não houve no Brasil a produção de escritos onde predominasse a imaginação poética ou ficcional, excetuando-se coisas tão insignificantes quanto o primeiro poema épico escrito em português, a Prosopopeia (1601), de Bento Teixeira (155? -1600) que só temo mérito da precedência ${ }^{235}$.

Há, pois, uma condição de memoriar a trajetória e os feitos da família de Duarte Coelho por meio de uma escrita que testemunha uma aventura dialética da 
viagem e da colagem do mito ${ }^{236}$, do herói, dos grandes feitos. E que inclui o Brasil, por meio de Pernambuco.

Proteu comunica essa coragem garantindo, através de uma composição épica, o dialogar sobre um fato histórico como argumento, o qual nos convida a promover a título de reconhecimento, amplificando os "feitos", a partir da Terra Brasilis, ao mesmo tempo que nos sugere a pensar numa função dialética, ou seja, como "prosopopear" o feito pela memória.

Observamos em Prosopopeia, a narrativa de cantar feitos de disputa contra aqueles que são colocados como inimigos da fé católica, como índios e mouros. A temática da guerra funciona como matéria que justifica a qualidade épica: há que se amansar os índios, domesticá-los, o que atesta a posição de vencidos, a título de formação de uma civilização e dos pressupostos de colonização em processo entre mundos sob os símbolo da conquista.

A resposta indígena é representada pelo autor graças a uma "dura cerviz bárbara", insolente, o que garante a guerra pela presença dos portugueses como necessários para se proceder à salvação das almas, "em busca da verdadeira religião" e posteriormente, à ocupação, organização do território e arrolamento das grandezas da Terra.

236 "O mito conta uma história sagrada; ele relata um acontecimento ocorrido no tempo primordial, o tempo fabuloso do "Princípio". Em outros termos, o mito narra como, graças às façanhas dos Entes Sobrenaturais, uma realidade que passou a existir, seja uma realidade total, o Cosmo ou apenas um fragmento: uma ilha, uma espécie vegetal, um comportamento humano, uma instituição. É sempre, portanto, uma narrativa de criação: ele relata de modo que algo foi produzido e começou a ser. O mito fala apenas do que realmente ocorreu, do que se manifestou plenamente. Os personagens dos mitos são os Entes Sobrenaturais. Eles são conhecidos, sobretudo, pelo que fizeram no tempo prestigioso dos "primórdios". Os mitos revelam, portanto, sua atividade criadora e desvendam a sacralidade ou simplesmente a "sobrenaturalidade” de suas obras. Em suma, os mitos descrevem as diversas, e algumas vezes dramáticas, irrupções do sagrado (ou do "sobrenatural” no Mundo). É essa irrupção do sagrado que realmente fundamenta o Mundo e o converte no que é hoje. E mais: é em razão das intervenções dos entes sobrenaturais que o homem é o que é hoje, um ser mortal, sexuado e cultural." ELIADE, Mircea. A Estrutura dos mitos: tentativa de definição do mito. In: Mito e Realidade. São Paulo, Editora Perspectiva, 1972. P.11. 
Por outro lado, a leitura de um texto colonial nos convida a pensar por muitas teias conexas e, na condição de leitores, embarcamos no jogo de tomar o atalho mais seguro, imaginando por conta e risco aquilo que o autor relata; entretanto nos encontramos diante de um impasse: temos aqui um texto que pretende autobiografar experiências vividas ou observamos uma obra que narra memórias, compondo a historiografia cartográfica do espaço? Esse espaço de fato existe ou foi imaginado? E quanto de veracidade ou de invenção as belas letras mascaram?

A narrativa compõe o desenho do deslocar-se por uma terra desconhecida, a terra que se constitui aos poucos, as relações humanas observadas na "sociedade" que se tenta organizar; as letras procuram traçar o caminho de interpretação, por meio do contexto em que o obra foi produzida. Ler e compreender o que o autor se propõe a contar não é uma tarefa fácil ao leitor, sobretudo se ele não se permitir algumas estratégias, se tratar de um leitor engessado pelos moldes da academia.

É preciso que ele, leitor, permita-se embarcar nos pressupostos em que a obra se desdobra hibridamente. Necessário se faz realizar o trânsito pelas palavras, sem tomar partido, com cautela, pois há que se decifrar práticas e costumes singulares a um tempo e a um espaço. Não podemos viajar na leitura dessas obras com olhos estáticos do presente. Há que se permitir uma dialética da mediação. 


\section{LER UM MUNDO DE SABERES}

Teu Poema

Tudo fiz para escrever o teu poema somente com o coração, porém não posso!

A culpa vem do fundo dos séculos... de meus troncos ancestrais:

- Senhores- de- Engenho com a pele tostada na ardência do sol!

- E um avô caboclo, com sangue de Arariboia, descendente de Tupã!

Com a chegada de Pedro Álvares Cabral ao Brasil iniciou-se a cristianização 238 destas terras chamadas inicialmente de Vera Cruz e, posteriormente, conhecidas

237 SILVA, Valéria Torres da Costa e (Org.). Cana Caiana, 1939. Como Polpa de Ingá Maduro: Poesia Reunida de Ascenso Ferreira. Recife: Cepe Editora, 2015, p. 155.

238 Nesse sentido, Sérgio Buarque de Holanda, em História Geral da Civilização Brasileira, lembra-nos acerca do ambiente da Europa cristã quando os documentos que deram origem ao direito de padroado, nos tempos modernos, foram escritos: "Ao início do século XV, o ambiente da Europa cristã era de terror ante o avanço descomunal dos turcos, que ameaçava todo o continente. Esforçavam-se os papas seguidamente, mas em vão, por organizar uma nova cruzada que salvasse o Oriente. É neste momento em que os feitos portugueses repercutem no ambiente da Santa Sé, como um primeiro sistema de reação cristã". 
como Santa Cruz. O primeiro contato religioso com os habitantes ao sul do Equador foi feito por franciscanos, sendo que oito foram os frades daquela ordem que estiveram presentes no advento do encontro entre dois mundos em terras tropicais.

A descoberta ${ }^{239}$

Seguimos nosso caminho por este mar de longo

Até a oitava de Paschoa

Topamos avres

E houvemos vista de terra.

O primeiro ato público na terra avistada, mais tarde nomeada como Brasil, foi a realização de uma missa, por Frei Henrique de Coimbra, sob o sol e o mar da Bahia, diante de etnias que observavam curiosamente a celebração solene, teatral. ${ }^{240}$ Com o primeiro governador geral, Tomé de Sousa, vieram os primeiros jesuítas para o Brasil, missionários do ofício do catequizar, do ensinar, do organizar e não menos do comunicar, pois foi preciso aprender a língua do outro.

A partir desses pressupostos jesuíticos, Padre Manuel da Nóbrega postula ao rei, o patrocínio do primeiro Colégio da Bahia, a ser dotado por D. Sebastião, no ano de 1564, afirmando que o fazia pelo provimento da catequese como seu dever. Fundou-se

239 ANDRADE, Oswald. Pero Vaz Caminha. Historia do Brasil. In: Pau Brasil. Paris: Sans Pareil, 1925.

240 “Filiação. O contato com o Brasil Caraíba. Ori Villegaignon print terre. Montaigne. O homem natural. Rosseau. Da Revolução Francesa ao Romantismo, à Revolução Bolchevista, à revolução Surrealista e ao bárbaro tecnizado de Keyserling. Caminhamos. Nunca fomos catequizados. Vivemos através de um direito sonâmbulo. Fizemos Cristo nascer na Bahia. Ou em Belém do Pará. Mas nunca admitimos o nascimento da lógica entre nós." ANDRADE, Oswald. Manifesto Antropófago. In: TELES, Gilberto Mendonça. Vanguarda europeia e modernismo brasileiro: apresentação e crítica dos principais manifestos vanguardistas. Petrópolis: Vozes, 1976.3ª Ed. 
então o Instituto dos Padres da Companhia de Jesus, para a conversão dos infiéis e gentios, bem como instrução dos novamente convertidos. Assim observamos como se instaura o princípio do ensinar na Terra Brasilis. ${ }^{241}$

Os índios ${ }^{242}$, por sua vez, desconheciam a leitura e a escrita. Era preciso iniciar o exercício das ciências e o que a época permitiu foi a possibilidade de instruir para aldear, catequizar e organizar o projeto de colonização ora pensado. ${ }^{243}$ Faltas não justificadas à escola era um dos delitos mais comuns nas aldeias. Durante o início de sistemas de aldeamento, procurou-se adaptar um sistema para os índios que se aproximava do modelo de civilizar as populações ${ }^{244}$ e o regime de tutela foi o escolhido.

241 "A vinda dos jesuítas para o Brasil é parte integrante do novo direcionamento da política econômica e administrativa portuguesa nas terras brasileiras. A economia açucareira era um elemento motivador para que tal ação fosse tomada, despontando como atividade altamente lucrativa." E: "Enquanto colonos, os jesuítas percebiam não só a posse da terra como condição da expansão da fé e do mercantilismo, mas principalmente a alteridade que o Novo Mundo lhes revelava. Uma cultura e uma visão de natureza que são registradas em suas cartas". ASSUNÇÃO, Paulo de. A Terra dos Brasis: a natureza da América Portuguesa vista pelos primeiros jesuítas (1549-1596). São Paulo: ANNABLUME, 2001. P. 70 e 71.

242 Para Darcy Ribeiro, "O Brasil é a realização derradeira e penosa dessas gentes tupis, chegadas à costa atlântica uns dois séculos antes dos portugueses, e que desfeitas e transfiguradas, vieram dar no que somos: uns latinos tardios de além-mar, amorenados na fusão com brancos e com pretos, "desculturados" das tradições de suas matrizes ancestrais, mas carregando sobrevivências delas que ajudaram a nos contrastar tanto com os lusitanos." RIBEIRO, Darcy. O Povo Brasileiro. São Paulo:

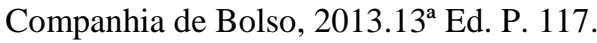

243 Waldemar Ferreira, em A Política da Proteção e Elevação das Raças Exóticas do Brasil nos Séculos XVI a XVIII, cita Serafim Leite: "era preciso civilizá-los, verbo que nos dicionários, tratando de nações ainda incultas, se chama colonizar. Colonizar o Brasil significava transformar brejos em campos cultivados, erguer cidades onde crescia o mato, educar os povos naturais e de costumes selvagens, como era no Brasil, por exemplo, o comer carne humana." NORONHA, Ibsen José Casas. Aspectos do Direito no Brasil Quinhentista. São Paulo: Almedina, 2008.

244 (Contra o Padre Vieira. autor do nosso primeiro empréstimo, 'para ganhar comissão'. O rei analfabeto dissera-lhe:ponha isso no papel mas sem muita lábia. Fez-se o empréstimo. Gravou-se o açúcar brasileiro. Vieira deixou o dinheiro em Portugal e nos trouxe a lábia). ANDRADE, Oswald. 
Nesse sentido, os colégios fundados em São Paulo e na Bahia foram nossas primeiras instituições de cultura no Brasil. Os jesuítas encontraram um estado de decadência moral bastante acentuado nos colonos que lá estavam, homens de costumes soltos e de uma linguagem desenfreada, que lhes tornavam o trabalho de catequização dificultado.

Observar nossa formação histórica, revisitando as instituições como o Estado e a Igreja é uma possibilidade de se pensar nas questões que os tempos atuais nos propõem como resultantes desse processo: mundo, sociedade, relações de poder, seja ele civil ou espiritual, no sentido de refletir sobre essa dialética das mentalidades nos trópicos, como possibilitar a construção de uma sociedade plural, tolerante e que resgate valores necessários para a consolidação democrática de fato.

Instala-se um pluralismo no interior da sociedade civil, facultando vias diferenciadas do exercício da vida moral e ética, ressalvados os dispositivos jurídicos estabelecidos pelo Estado. Tolerância, respeito e liberdade, de um lado, de outro, respeito e neutralidade constituem princípios de igualdade perante a construção de uma ordem política baseada na convivência rica e pacífica. ${ }^{245}$

As caravelas ${ }^{246}$ também trouxeram a poética do pragmatismo, do navegar para a prática do apropriar. Nessas bases o Brasil foi encontrado para literatos,

Manifesto Antropofágico. In: TELES, Gilberto Mendonça. Vanguarda européia e modernismo brasileiro: apresentação e crítica dos principais manifestos vanguardistas. Petrópolis: Vozes, 1976.3ª Ed.

245 Cury, Carlos Roberto Jamil. Laicidade na República Federativa do Brasil.

246 "O Brasil é um país de muitas faces, uma terra de mil povos que habitaram as grandes planícies, matas nativas e encostas, muito antes da chegada das caravelas que por aqui atracaram a caminho das Índias; da procura por outras rotas de navegação, os conquistadores portugueses encontram gente; em busca das riquezas e opulência da terra, esses viajantes se depararam com as diversidades da natureza e a alteridade da vida nos trópicos". Introdução do artigo que produzimos para UNIFMU, para o Curso de Pós Graduação em Direito Ambiental, sob o título Cultura e Direito Ambiental: a Tutela Constitucional Protetiva. São Paulo, UNIFMU. 2014. Discorre sobre o Patrimônio Imaterial, com o objetivo de observar a tutela jurídica dos bens culturais como patrimônio imaterial, sob a interface do Direito Ambiental, com finalidade de refletir sobre a circulação e proteção de saberes necessários à preservação 
conquistado ou descoberto para historiadores. Caminha, na condição, escreveu a Carta de Achamento do Brasil e assim surgimos na condição do registro. A terra e suas gentes arroladas a partir de um documento cujo gênero textual Carta noticia que há viventes nos trópicos e uma infinidade de grandezas a ser contada; com base no registro, práticas e costumes, a partir de um texto escrito tenta explicar para o Velho Mundo aquilo que não se conhece, mas que graças ao advento do contato, precisa explicar.

O Cabralismo. A civilização dos donatários.

A Querencia e a Exportação. O Carnaval. O Sertão e a Favella.

Pau-Brasil. Barbaro e nosso.

A formação ethnica rica. A riqueza vegetal. $O$

Minério. A cosinha. O vatapá, o ouro e a dansa.

Toda a historia da Penetração e a historia

Commercial da America. Pau-Brasil. ${ }^{247} 248$

Nesse sentido, a produção textual realizada no Brasil Colônia foi tecida graças a uma matriz portuguesa ${ }^{249}$ e, por essa razão, nossa gênese textual demanda uma

do repertório imaterial investigado, como pressuposto de defesa ao direito do aprender, pelas leituras e vivências, saberes promotores da cultura de paz, bem como aquisição de conhecimento como tutela de preservação, como garantia constitucional ao direito ao conhecimento para as futuras gerações.

247 ANDRADE, Oswald. Falação. In: Pau Brasil. Paris: Sans Pareil, 1925.

248 "Sua poesia tem o sabor de folha verde" - foi tudo o que pude falar, antes que ele de novo me abraçasse e fosse embora. Nunca mais o vi, mesmo porque, um mês depois, ele morria em sua casa, em São Paulo". Gullar, Ferreira. Encontro com Oswald. São Paulo. Folha de São Paulo, 12 de junho de 2016.C8 Ilustrada. http://www1.folha.uol.com.br/colunas/ferreiragullar/2016/06/1780387-encontro-comoswald.shtml Acesso em 12 de junho de 2016.

249 "Minha pátria é a língua portuguesa". Fernando Pessoa. http://multipessoa.net/labirinto/bernardosoares/ "Gosto de sentir a minha língua roçar a língua de Luís de Camões." E: "Flor do Lácio Sambódromo Lusamérica latim em pó / O que quer / O que pode esta língua"? E ainda: "A língua é 
leitura crítica de interpretação híbrida, a qual necessariamente precisa passar por um instrumental histórico para se considerar a perspectiva do leitor diante da diversidade textual produzida, como $\operatorname{cartas}^{250}$, diários, epopeias, histórias, crônicas, como condição de construção do processo de ler para decifrar o contexto histórico e a arquitetura textual vigente.

\begin{abstract}
A arte do jogo ${ }^{251}$ mais jogado pelos campos do Brasil, do campinho de terra, areia ou gramado, está aí para corroborar as mil faces de que somos feitos: herança de uma formação étnica híbrida, cuja base parte do índio, alcança o branco e encontra o negro, num banquete cultural único, o qual hoje, nossa essência é emprestada para explicar o processo, a dinâmica das civilizações em circulação pelo mundo."

252253
\end{abstract}

minha pátria / E eu não tenho pátria, tenho mátria / E quero frátria / Poesia concreta, prosa caótica / Ótica futura / Samba-rap, chic-left com banana". In: Língua, Caetano Veloso. https://www.letras.mus.br/caetano-veloso/44738/

250 Quanto ao ofício artístico das Cartas escritas pelo Padre Vieira, Hansen nos informa que: “o habito é uma qualidade firme e estável que decorre da experiência; diferentemente da arte da prudência, a arte epistolar encontra seu princípio, aristotelicamente doutrinado, na emulação de casos tradicionais formalizada numa técnica, que é ensinável, como no tempo em que Vieira foi mestre de Retórica em Olinda. Tanto mais nobre será a arte como mais nobre será o seu fim”. HANSEN, João Adolfo. Introdução. In: Cartas do Brasil. 1626-1697. Estado do Brasil e Estado do Maranhão e Grão Pará. São Paulo: Hedra, 2003. P.24.

251 Segundo Wisnik, ao citar Gilberto Freyre, o futebol brasileiro extraía as qualidades de luta dançante da capoeira para fins decididamente lúdicos e estéticos, através dos "bailarinos da bola", por oferecer um efeito de comprovação prática da interpretação cultural em andamento: "o alcance mais engenhoso $e$ inovador dessa formulação é que ela extraía a sua potência afirmativa dos próprios estigmas da escravidão, como uma operação simbólica que extraísse do veneno o próprio remédio.” WISNIK, José Miguel. Veneno remédio: o futebol e o Brasil . 1.ed.São Paulo: Companhia das Letras, 2008.

252 RINALDI, Lucinéa. Cultura e Direito Ambiental: a Tutela Constitucional Protetiva. São Paulo, UNIFMU, 2014.

253 Acrescente-se a isso a ideia de que, aos olhos do outro, o mundo contemporâneo está cada vez mais "se abrasileirando", ao repensar suas fronteiras, ao discutir etnia, língua e religião, vilipendiando direitos humanos internacionais em nome do capital, a medida que observamos os grandes muros reais e 
Assim se constituiu o Brasil, pelo canto das três raças ${ }^{254}$ e que, mais tarde, reembarcou tantos outros povos para aqui plantar café, fornecendo mais do que mão de obra: sonhos plantados pelos muitos caminhos abertos na mata." Homens que trouxeram conhecimento e práticas agrícolas seculares, graças aos saberes incorporados pelo contato e circulação com outros povos 255 .

Nesse sentido, viajar foi preciso para encontrar terra e trabalho $e$, as sementes plantadas por mãos brancas e negras, agora "escravas" pelo jogo do capital, geraram acúmulo de riquezas aos cafeicultores, fato esse que possibilitou a São Paulo deixar de ser uma vila e ganhar, mais tarde, o estatuto de "locomotiva de um Brasil que se formava". A substituição do engenho pelo cafezal indicou a direção, rumo pensado e proposto para a noção de povo em processo de construção, afastando nossa ancestralidade indígena e embranquecendo nossa constituição africana. ${ }^{256}$

Há que se pensar aqui nas muitas fronteiras que permeiam a literatura quando nos damos conta de que estamos diante de um gênero híbrido, o qual ventila muitos debates. Pensemos na condição do deslocamento como possibilidade de comunicação, de acesso ao outro, de uma intenção de registrar aquilo que olha, compara com o referencial que ele autor, conhece, na tentativa de descrever cartograficamente a terra e sua gente, como um estrangeiro que transviaja entre o mar e o sertão.

imaginários que separam continentes, transformando mares num autêntico cemitério de refugiados, como uma tentativa de escapar do flagelo humano motivado pela fome, guerra, religião, etnia, subemprego ou trabalho escravo, documentado, sobretudo, por Sebastião Salgado.

254 E ainda: "a sociedade e a cultura brasileira são conformadas como variantes da versão lusitana da tradição civilizatória europeia ocidental, diferenciadas por coloridos herdados dos índios americanos e dos negros africanos. O Brasil emerge, assim, como um renovo mutante, remarcado de características próprias, mas atado geneticamente à matriz portuguesa, cujas potencialidades insuspeitadas de ser e crescer só aqui se realizariam plenamente. Ribeiro, Darcy. O Povo Brasileiro. São Paulo: Companhia de Bolso, 2013. 13.ed. P.17 e 18.

255 RINALDI, Lucinéa, op. cit.

256 idem. 
Ler e refletir sobre o que a obra nos conta, sobre o que percebemos na concepção dessa narrativa, é uma opção a ser buscada, evitando-se o rótulo canônico observado nos livros didáticos, os quais nomeiam autores e suas produções, segundo escolas literárias, nos compêndios clássicos de literatura. Portanto, não há que se traçar uma concepção que a explique ou como obra literária ou histórica, mas a relevância de se pensá-la como um texto esteticamente preconcebido.

Recuar um pouco é preciso, como nos ensina Bosi, no capítulo as fronteiras da literatura, nos orientando no sentido de que falar em "fronteiras" da literatura é também pensar o campo das interações, sobre diferenças entre "ficção" e “não ficção." Há que se refletir aqui na condição da experiência. Ainda que mais tênue nos pareça, existe sim um momento fronteiriço.

A obra nos permite esse jogo dialético entre "atestar o verificável" e como leitor que recepciona o contexto por meio de um texto em que ele duvida dos fatos ali narrados.

A escrita desse mundo com que tomamos contato pela leitura, relativizando grandezas, pela grafia, a qual molda uma possibilidade de retrato etnográfico da paisagem colonial e de sua gente, remete-nos a pensar no papel que as fontes fornecem para conhecer a cultura em circulação e como ela se coloca no cotidiano.

Refletir sobre a condição da cultura, a partir de diálogos, testemunhos, descrição, construção da paisagem, bem como acompanhar como as narrativas possibilitam o diálogo do processo de forma interdisciplinar, melhor explica o ponto onde estamos ${ }^{257}$, auxiliando ao leitor, ao pesquisador a percepção de possibilidade de tradução de um mundo relatado pelas narrativas que, graças à circulação das condicionantes que o contexto nos permite desvendar, recepcionam múltiplas possibilidades de interpretação.

257 "Estudar as narrativas de viajantes significa tatear por terrenos movediços, tão inseguros para a história quanto foram os caminhos desconhecidos para quem os descobriu e percorreu." e: "Para um mundo que, ao mesmo tempo, se ampliava e reduzia, à medida que seus limites, outrora desconhecidos, foram sendo descobertos e controlados, a partir de múltiplas estratégias de conquista, também deveriam ser descobertas novas formas de narrativa que pudessem dar conta do cenário que se queria descrever." MICELI, Paulo. O Ponto Onde Estamos. Campinas, Editora UNICAMP, 2008. P.29 e 30. 
Há toda uma condição voltada para o campo da escrita, das vozes sobre os discursos presentes e ausentes do texto que se coloca per si, cabendo ao leitor decifrar o mundo que cartograficamente se constitui pelo narrar, como possibilidade de experimentar o novo pelo contato com o outro, com a natureza arrolada, com base no que se vê e não se reconhece, a escrita que se tece sobre terra e gentes a partir da colagem de um repertório de leitura pertencente a outro contexto, tempo e espaço ${ }^{258}$.

Por meio da leitura e análise de narrativas e dos processos de escrita que descrevem, relatam ou ilustram mundos diversos, questões são levantadas para uma reflexão que necessariamente permeia diferentes chaves de interpretação possíveis, como: estamos diante de um documento que realiza o inventário, nomeando seres e lugares ao narrar uma viagem experimentada, chancelada pelo testemunho? Ou de um relato que cartograficamente atesta grandezas e opulências de uma geografia descritiva do imaginário? $\mathrm{Ou}$, ainda, nos encontramos diante um narrador que, pelo encontro com um mundo diverso, enuncia ${ }^{259}$ o contar sobre a terra e suas gentes, a partir de um repertório lido, imaginado e experimentado, promovendo um discurso que parte da memória e alcança a invenção? ${ }^{260}$

258 Ao tratar de perspectiva geográfica, Jean-Marc Besse afirma que "a paisagem" não é definida de início como extensão de um território que se descortina num só olhar desde um ponto de vista elevado, segundo a fórmula tomada clássica a partir do século XVII. Na história da pintura, ela é entendida como espaço objetivo da existência, mais do que como vista abarcada por um sujeito. BESSE, Jean-Marc. Ver a Terra. Seis Ensaios sobre a Paisagem e a Geografia. São Paulo, Perspectiva, 2006. P. 21.

259 "A compatibilidade entre as interpretações feitas pela enunciação e por personagens em ato e os atos de interpretação das recepções diferenciadas que conferem sentido e valor aos discursos". Referência de Roger Cartier, Dandin ou Le social em répresentation, em artigo publicado em Annales, Littérature ET histoire (Paris), Armand Colin, p.283, n. 2 março-abril. HANSEN, João Adolfo. Barroco, Neobarroco e outras ruínas. Teresa. Revista de Literatura. São Paulo, USP Editora 34, 2001. P.25, ao tratar questões como "subjetividade piscológica" nas representações coloniais.

260 “O que é próprio do saber não é nem ver nem demonstrar, mas interpretar." Para Foucault, não se solicita a esse discurso que se interprete seu direito de enunciar uma verdade, mas somente requer dele a possibilidade de falar sobre ele. FOUCAULT, Michel. As Palavras e as Coisas. Uma Arqueologia das Ciências Humanas. São Paulo. Martins Fontes, 2011. 
Num primeiro momento, vivenciar a escrita da história como prática constituída mediante o contato com o outro, a necessidade de se comunicar com ele, por sua base e repertório de estudos e de leitura, ao conhecer e decodificar as fontes do processo de contato, conquista e conhecimento de mundos; num segundo momento, permite que a escrita da história dialogue com mundos diversos.

Ao pesquisador que investiga as narrativas e os discursos coloniais, revisitar e revisionar a circulação desses textos de informação é sempre um convite para se colocar a percepção do outro em relação à cartografia imaginada e descrita, a territorialidade que se coloca, por meio de uma epopeia ou de uma viagem descrita, fundamental para se observar e pensar o ponto onde estamos, no universo da leitura, entre o campo do escritor e o do leitor.

Ler e pensar sobre narrativas, poéticas e memórias coloniais, sob a égide de comunicar mundos, mediante o diálogo e a reflexão com o presente, precisa fazer parte da estratégia de análise e reflexão dos estudos de forma interdisciplinar, porque subsídios e repertório de fontes promovem uma melhor compreensão sobre o contato, o encontro com o outro e com novas dinâmicas de transformação da civilização como um processo. 


\section{DESEMBARQUE}

1.

Prosopopeia $^{261}$

Quem sou eu para te cantar, favela,

Que cantas em mim e para ninguém a noite inteira de sexta-

feira

e a noite inteira de sábado

e nos desconheces, como igualmente não te conhecemos?

Buscar leituras e discussões interdisciplinares foi preciso, no sentido de amparar questões levantadas pela pesquisa, para compreendermos as ferramentas de análise textual relevantes, com finalidade de perceber processos e discursos.

Assim, como a composição da tela, a épica reflete a poética de circulação entre mundos, com base no molde, na estética construída, a partir de um autor / leitor o qual constrói, por meio da rima e do verso, seu cantar. Com esse atributo, alcança a representação do mundo ficcional pela arte da composição, fazendo uso poético do gênero textual corrente ao seu tempo.

O poeta, na solidão, recupera essa fortuna lida e recolhe suas memórias, ao compor o retrato escrito em forma de poema; com grandeza estética, usa a linguagem da arte como possibilidade de clemência ou salvo conduto, a pena como instrumento de defesa, ele, conhecedor dos dogmas, merecedor do perdão.

261 ANDRADE, Carlos Drummond. Favelário Nacional. In: Poesia Completa. Rio de Janeiro: Editora Nova Aguilar, 2003. 
Por outro lado, o gênero textual usado com base no testemunho, realiza a crônica de um Brasil Colônia pela paisagem física e humana: percebe espaços e as relações de poder vigentes, atestam um tempo e um lugar alegoricamente criados a partir do olhar estrangeiro; realiza, ainda, a crônica descritiva do espaço e das relações humanas, ao narrar memórias e vivências entre o sertão e o mar.

Interessa-nos, sim, pensar como a linguagem presente nessas práticas coloniais traduzem, graças ao gênero textual em circulação, discursos necessários para o debate por meio da arte, ao cantar e narrar nossas primeiras letras, ainda que não "belas". O domínio da leitura e da escrita, nos tempos coloniais, era um poder para poucos artesãos da linguagem. Saber imitar com arte era um poder para poucos diante de uma sociedade iletrada.

Feito isso, uma necessidade se coloca e nos instiga a pensar, a partir dos processos da escrita realizada pelo poeta e pelo viajante: como recuperar o lugar em que se observa a arte e a estética épica de um "poemeto", bem como de uma narrativa descritiva, a qual realiza o arrolamento das "grandezas" e dos lugares que, cartograficamente, tecem a paisagem por meio do olhar e do escrever sobre o desconhecido.

Nesse sentido, necessário se fez abrir a gaveta dos guardados para alcançar uma interpretação literária como condição de embarque, no sentido de pensar a narrativa escrita como fortuna de um processo em circulação: cantar um feito histórico, narrar terras e gentes "redescobertas".

$\mathrm{Na}$ condição de ruptura com o academicismo, a estratégia foi guardar na gaveta o olhar pronto da crítica literária e da historiografia, uma vez que as narrativas coloniais revisitadas, ainda recepcionadas como não canônicas, necessitam de debates e conversas no plano da pesquisa e da reflexão.

Dessa forma, necessário foi partir pelo atalho da arte para observar as poéticas coloniais, pelo resgate de uma escrita a qual ilustra, retrata e oferta-nos o desenho da terra e da gente pela composição da paisagem narrada, a qual nomeia lugares, reconfigura o mapa, em perspectiva com discussões contextuais necessárias. 
Dentre as muitas gavetas e os muitos guardados, foi preciso embarcar na condição de turista aprendiz, por questões que experimentam, pelo caminho da leitura, o acesso ao conhecimento de um mundo pluricentrado num rol de saberes.

Sobre essa condição, encontramos, ou melhor, reencontramos a sugestão proposta por Mário de Andrade quanto ao degustar o caldo servido como banquete, ao embarcarmos pela experiência de recepção textual; por aprendizagens antropofágicas (Oswald de Andrade) e tropicais (Caetano Veloso) ponderadas por uma fortuna jesuítica de formação, porque estamos a falar de uma terra e de sua gente, ainda que a noção de Brasil nos chegue mais tarde. Drummond, com o Favelário Nacional, ajuda-nos a mediar esse debate.

Guardadas as reflexões acadêmicas em processo, fizemos uso de uma tática mariodeandradediana ${ }^{262}$ : evitamos levar o olhar pronto, estabelecido pela crítica literária feita pelas vozes históricas que pensaram e explicaram o poema e a viagem, afastando o artístico em detrimento da imitação, sequestrando, por ora, a aparência como "ruína", privilegiando uma interpretação isolada. Embarcamos no risco e na aventura que toda viagem nos convida a experimentar, pelo acaso e descoberta.

Assim, pensar a escrita como um processo de constituição do retrato, dialogando com outros campos do conhecimento e práxis de composição de um texto, seja ele uma narrativa ou um quadro, passou a ser um atalho possível de articular produção literária estética com função discursiva, com a finalidade de repensar o que a narrativa colonial nos comunica.

Pensar a base para os estudos literários parte desses pressupostos coloniais para a devida discussão acadêmica, no sentido de se perceber o ponto em que estamos, movediço, dos estudos estéticos, percebendo que essa pré-concepção de classificar

262 "Não sei, quero resumir minhas impressões desta viagem litorânea por nordeste e norte do Brasil, não consigo bem, estou um bocado aturdido, maravilhado, mas não sei... Há uma espécie de sensação fincada da insuficiência, da sarapintação, que me estraga todo o europeu cinzento e bem-arranjadinho que ainda tenho dentro de mim. “ 18 de maio. ANDRADE, Mário. O Turista Aprendiz. São Paulo: Livraria Duas Cidades, 1976. P.60 e 61. 
momentos em períodos recepciona vozes da historiografia, a qual se formou sob a égide de uma concepção hegeliana (de sucessão) e kantiana (prática). ${ }^{263}$

Nesse sentido, há que serem incluídos, nos debates acadêmicos, momentos, instantes de criação ou provocação literária sobre o período colonial, questionando a condição proposta e herdada de linearidade dos estudos árcades e barrocos do período, ao sugerir a necessidade de se resgatar, para o campo dos estudos literários, uma proposta de revisitar a singularidade dos escritos coloniais enquanto ruínas, resíduos, para uma arqueologia devida do campo dos saberes, então sequestrada, destituída dessa visão positivista, institucionalizada enquanto "formação" como cânone.

Ainda, a proposta aqui é ler e investigar os escritos, levando-se em consideração outros conceitos, como tempo (circulação), arte (gênero) e público, como concepção universal.

Hansen recorda-nos da necessidade de retorno para os clássicos, sobretudo quando pretendemos ler Vieira. Há que se realizar uma leitura a partir do que nos propõe Santo Agostinho e Cícero, no sentido de se perceber a oratória como imitação e a especificidade das práticas de representação. Autores como Chartier e Certeau, segundo ele, nos ajudam a alcançar um modo de leitura e compreensão de narrativas que cruzaram séculos e que alcançam a contemporaneidade.

Assim, devem-se articular processos de leitura, no sentido de instrumentalizar a interpretação pela recepção dos gêneros em circulação pela arte, estética e fortuna textual tecida, qualifica nosso modo de olhar e de recepcionar autores, artistas e suas composições, uma vez que não se encontravam sob a égide da concepção burguesa de produção, voltada ao universo atual que versa sobre direitos autorais e plágio. Essas questões não se colocam em tempos de letras coloniais. Imitar não significava plagiar.

263 Em conferência ministrada no $2^{\circ}$ Seminário de Pós-Graduação em Literatura Brasileira, março de 2016, na USP, o Prof. João Adolfo Hansen revisita e nos convida para o debate necessário quanto a se pensar como conceituar momentos de historiografia da literatura brasileira. 
Hansen lembra-nos sobre a paisagem política colonial vigente na Bahia, no Grão Pará e no Maranhão, bem como da concepção da "Ratio Studiorum", a qual permitia que os jovens entre 7 e 14 anos, em idade escolar, sob o modelo jesuítico, realizassem a leitura de clássicos greco-latinos e fossem latinizados sob a proteção e o projeto de um estamento monárquico em construção.

Nesse sentido, Hansen nos orienta a ler, estudar e a investigar textos coloniais segundo uma visão diacrônica, livre, de resgate de poética e de narrativas constituídas de vários sistemas de representação, as quais dialogaram com outras obras em circulação, a exemplo do fazer estético de Aleijadinho, cujo método de trabalho ao conceber suas formas, recepcionou e conversou com o Barroco de Praga do século XVII e com o Pergamon de Berlim. Isso dentro de uma cátedra de pesquisa que somente a universidade pública nos chancela.

Ele ainda nos fornece os fundamentos de pensamento, de aproximação, para a percepção quanto à produção, manutenção e circulação dessas artes, com base nos códigos, discursos e os modelos bibliográficos, como necessidade de se voltar para a investigação dessas ruínas, ainda que a pesquisa sobre literatura, em tempos atuais, sofra de ausência de prestígio.

Voltar-se para um campo de investigação, negligenciado pela vontade de mercado trata-se de uma postura de enfrentamento: desafiar um sistema que desprestigia a aprendizagem e a aquisição de saberes literários, como estratégia de retirar a possibilidade do conhecer, do direito de aprender e a condição do instruir para o ofício do pensar, cada vez mais perigoso para o paradigma do modelo de certificação da educação em massa, alienada e incapaz de promover a mobilização de transformação devida pelo aprender.

É função da pesquisa numa universidade pública reivindicar como direitos de aprendizagem todos os saberes, uma vez que estamos considerando um corpus literário que foi produzido antes da concepção de um país como nação.

Hansen, ao refletir sobre os estudos coloniais, atesta que ainda há muita discussão acadêmica sobre investigar ou não toda essa "velharia" colonial, vozes que pensam o campo de investigação do barroco como manco, menor, desconhecendo os 
debates que generalizam o que deve ser considerado como canônico ou não na historiografia literária, bem como seus pressupostos romântico-burgueses de inauguração ou de formação dos estudos literários.

Somos um país que ainda não pensou a escolarização como devida. Para Darcy Ribeiro, "a crise da educação no Brasil não é uma crise, mas um projeto". ${ }^{264}$

Herdamos um modelo educacional de exclusão, secularmente alimentado pela escravidão, vilipendiado pela ditadura, modificado por ações e projetos de recorte de disciplinas e competências e agora sequestrado por políticas públicas com maior finalidade eleitoral do que pedagógica e pensamos, sobretudo, na alteração dos conteúdos e parâmetros mínimos modificados por bases curriculares que, mais atendem vontades e finalidades institucionais, mediante a propaganda política de "descolonizar conteúdos" por meio de "teias" ou "territórios" do saber, enquanto a vocação da Educação como agenda, deve se voltar na direção, a qual proporciona diretrizes curriculares com conteúdos mínimos pertinentes aos legítimos direitos constitucionais de aprendizagem.

Após uma formação acadêmica pluridisciplinar, com uma prática pedagógica de aproximadamente três décadas, com efetivo exercício de licenciatura, pensamos que, políticas públicas reducionistas, seletivas, fazem uso de termos como "territórios" para, na verdade, construíram fronteiras, edificando muros e não pontes de aprendizagens.

Entendemos que as diretrizes curriculares nacionais são instrumentos devidos e que devem uniformizar as aprendizagens mínimas em todo o território nacional. Alterar parâmetros ou permitir a escolha do que e como aprender conteúdos de língua, literatura, cultura e história, pode alterar a formação devida, uma vez que essas disciplinas instrumentalizam nossos alunos ao ofício do interpretar, capacitandoos a pensar e a debater para questionar o mundo onde vivem, base ${ }^{265}$ necessária para a

264 http://www.revistaforum.com.br/digital/75/entrevista-com-mario-sergio-cortella-o-unico-criterio-deverdade-e-a-pratica-1a-parte/. Acesso: 02 de maio de 2016.

265 Segundo a Base Curricular, Cervantes e Fernando Pessoa não são obrigatórios nos bancos da escola. 
formação devida, constitucionalmente garantida. Fragilizar as aprendizagens nesses campos atende a uma vontade institucional atual, somente encontrada nos tempos da ditadura militar, a qual, de fato, cerceou direitos de aprendizagens e exercícios significativos de expressão.

Como pensar no direito à aprendizagem dos textos literários se não há equidade quanto ao tempo em que deve o aluno permanecer na escola pública? Como capacitar o aluno a ler e a compreender se, na maior parte delas, sequer há biblioteca? E como pensar numa qualidade de ensino e de aprendizagem se na Base Nacional Comum Curricular em debate, observamos fumaça de sequestro quanto aos estudos de literaturas de língua portuguesa?

Pensar os escritos coloniais segundo um modelo vigente e olhar para a universidade pública hoje, convida-nos a repensar não somente o gênero textual ausente, agora sequestrado do currículo escolar, mas nos propõe a provocar toda uma nação, republicana, a refletir que, essa ausência quanto ao direito de preservação da memória, construído a partir das ferramentas do aprender pela leitura e pela interpretação, resulta na maior catástrofe secular que evidenciamos hoje: grande parcela da população brasileira constitui-se como funcionalmente analfabeta, número esse que encosta ou supera a população brasileira iletrada do século XVII. ${ }^{266}$

Finalmente, não cabe a literatura a tarefa de funcionar como registro da realidade, nem deve a ficção ser confundida com documentos que inventariam a memória literária de escritores e seus escritos. Pertence, contudo, ao campo dos estudos literários, a possibilidade de atuar como base de conhecimento e de aprendizagem para a devida formação, a escolarização pela estética do pensar para o interpretar, bem como a aquisição do conhecimento linguístico voltado para a preservação dos usos e práticas da língua e da cultura.

266 (De acordo com os últimos dados do INAF, 75\% dos brasileiros são considerados analfabetos funcionais. Isso mesmo: 3 em cada 4 brasileiros. Destes, $8 \%$ são analfabetos absolutos, 30\% lêem mais compreendem muito pouco e $37 \%$ entendem alguma coisa mas são incapazes de interpretar e relacionar informações). http://www.geracaobooks.com.br/literatura/texto1.php. Acesso em 02 de agosto de 2016. 
No entanto, cabe à literatura a capacidade de tergiversar e dialogar com outros campos onde discursos e estética funcionam como areia movediça para o historiador; relatos e narrativas como intenção para o antropólogo.

Como pensar nas políticas públicas do ler, do escrever se observamos que boa parte dos professores, titulares ou em exercício, apresentem carência quanto à formação, sobretudo literária, uma vez que professam mais o ofício do fazer e do corrigir exercícios, mecanicamente, ou a capacitar os alunos a reconhecerem a resposta correta e, realizam menos o exercício do ler, do interpretar e do criar como atividade em sala de aula?

Dialogar, de forma interdisciplinar, com a prática do pesquisar e do ensinar, facilita a percepção da necessidade de construção e de circulação de saberes, com finalidade de promoção da cultura de paz e cidadania digna, sobretudo em tempos que, por um lado, acompanhamos o Brasil a se colocar, teoricamente, como uma Pátria Educadora e, por outro, de dentro dos muros da escola, atestamos que o discurso institucional diverge da práxis efetiva.

Pensar a narrativa do ensinar e do aprender, entre a escrita da tese e da aula nossa de cada dia, permite-nos perceber as bases para a devida aprendizagem, como garantia legal quanto à formação do brasileiro: quais pressupostos são necessários para aprender a ler com qualidade, para aperfeiçoar o repertório de leituras e como disponibilizar uma variedade de textos que falam sobre nossa condição como povo.

Ainda, estudar a interface do ler e do conhecer, a partir das nossas primeiras letras, funciona como uma necessidade a medida que aprendemos a perceber como um inventário de ideias facilita nossa percepção de quem somos hoje, por meio de ações positivas, vigilantes.

Demandar a necessidade dos estudos coloniais não significa reivindicar o estatuto de colonizar, ratificar a prática do canonizar saberes, mas retirá-los do silêncio, da ausência dos estudos, escolares e acadêmicos, e agregá-los ao rol de saberes necessários para a devida formação escolar, como resguardo e vigilância quanto ao direito à aprendizagem de conteúdos que possibilitem ao aluno adquirir saberes de fato e de direito, com formação digna, constitucionalmente assegurada. 
A percepção dessa teia viciada que sequestra saberes, sucateia a escola como um todo e silencia campos literários, luso-brasileiros, coloniais, precisa buscar uma compreensão na historiografia que pensa a terra e as gentes do Brasil em processo de formação, a partir de suas bases, suas primeiras letras, belas ou não, canônicas ou não, como tentativa de reconstruir, pela linha do tempo, a compreensão da condição em que nos encontramos hoje: uma nação que não privilegia o ler, a aprender, uma pátria educadora, idolatrada na letra da lei, mas que não inclui seus filhos como mãe gentil. 


\section{BIBLIOGRAFIA}

ABREU, Capistrano de. Capítulos de História Colonial. 1500-1800. 1. Ed. 1906.

ADORNO, Theodor W. Notas de Literatura I. Coleção Espírito Crítico. São Paulo: Livraria Duas cidades / Editora 34, 2003.

ALMEIDA, Guilherme de. Do sentimento nacionalista na poesia brasileira. São Paulo: Casa Garroux, 1926.

ALVES, Luiz Roberto. Fábula em busca da História: relações entre as narrativas manuscritas de Bento Teixeira e o poema Prosopopeia. São Paulo: USP, Dissertação de Mestrado, 1977.

Confissão, poesia e Inquisição. São Paulo: Ática, 1983.

AMORA, Antônio Soares. A Prosopopeia, de Bento Teixeira, à luz da moderna camonologia. Lisboa: Universidade de Lisboa, 1957.

A Prosopopeia e seus temas de interesse. São Paulo: O Estado de São Paulo, Suplemento Literário de 22/02/1956.

ANDRADE, Carlos Drummond. Poesia Completa. Rio de Janeiro: Nova Aguilar, 2003.

ANDRADE, Mário de. 1988. Macunaíma. O Herói sem Nenhum Caráter. Org. Telê Ancona Lopez. 26. Ed. Belo Horizonte - Rio de Janeiro: Villa Rica, 1990.

O Turista Aprendiz. São Paulo: Livraria Duas

Cidades, 1976.

ANDRADE, Oswald. Do Pau-Brasil à Antropofagia e às Utopias. Editora Civilização Brasileira, 2a Edição. Obras Completas, V. 6, 1978. 
. O Santeiro do Mangue e Outros Poemas. São Paulo:

Globo, 1991.

. Pau Brasil. Obras Completas. São Paulo: Globo, 1991.

ANDREOTTI, Maria Elaine. A Selva Europeia e o Paraíso Tupinambá: tópicas sobre mundos na história de uma viagem ao Brasil de Jean de Léry. São Paulo: dissertação de mestrado. Área de Literatura Brasileira, USP, 2013.

ARISTÓTELES, Horácio, Longino. A Poética Clássica. São Paulo: Editora Cultrix, 2011. (Introdução de Roberto de Oliveira Brandão).

ASSUNÇÃO, Paulo de. A Terra dos Brasis: a natureza da América Portuguesa vista pelos primeiros jesuítas (1549-1596). São Paulo: ANNABLUME, 2001.

AUBERT, Francis H., As (In) Fidelidades da Tradução. Campinas: Editora da UNICAMP, 1993.

Procedimentos Básicos de Terminologia. São Paulo: In

Caderno de Terminologia, n.2, CITRAT, 1996.

AUERBACH, Erich. O Escritor Montaigne. In: Ensaios de Literatura Ocidental. São Paulo: Livraria Duas Cidades / Editora 34, 2007.

. Mimesis. Estudos. São Paulo: Editora Perspectiva, 2002.

BANDEIRA, Manuel. Crônicas da Província do Brasil. São Paulo: Cosac Naify, 2006.

BARROS, Diana Luz Pessoa de (org.). Os Discursos do Descobrimento. São Paulo: Edusp, 2000.

BASTO, Dani. Coco de Umbigada. Cultura Popular como Ferramenta de Transformação Social. Recife: Daniela Bastos dos Santos Editora, 2011. 
BENTON, Lauren. A Search for Sovereignty. New York: Cambridge University Press, 2011.

BESSE, Jean Marc. Ver a Terra. Seis Ensaios sobre a paisagem e a geografia. São Paulo: Perspectiva, 2006.

BHABHA, Homi. O Local da Cultura. Belo Horizonte: UFMG, 2010.

BLOCH, Marc. Apologia da História ou o Ofício do Historiador. Rio de Janeiro: Jorge Zahar Editor, 2001.

As Grandezas da Terra Novas: Questões sobre a Geografia Europeia Moderna (séculos XVI a XVIII). Aula 1 proferida em São Paulo: na Cátedra Jaime Cortesão, da FFLCH, USP, em 25/02/2014.

Cosmografia e geografia no século XVI, matemática, história, religião (Finé, Münster, Possevino). Aula 2, proferida em São Paulo: na Cátedra Jaime Cortesão, da FFLCH, USP, em 28/02/2014.

BOITANI, Piero. Naufrágio: Interpretação e Alteridade. In: A Sombra de Ulisses. São Paulo: Editora Perspectiva, 2005.

BONALD Neto, Olímpio. Os Gigantes Foliões em Pernambuco. 2.ed. Recife: Companhia Editora de Pernambuco, 2007.

BOPP, Raul. Cobra Norato. São Paulo: José Olympio Editora, 2001; 1999. 'Cobra Norato'. in Poesia Completa. Org. Augusto Massi. Rio: José Olympio; São Paulo: EDUSP, 1998.

BOURDIEU, P. O Mercado de Bens Simbólicos. In: A Economia das Trocas Simbólicas. São Paulo: Editora Perspectiva, 2013.

. Esboço de Auto-Análise. Tradução, introdução, cronologia e notas Sérgio Miceli. São Paulo: Companhia das Letras, 2005.

BOSI, Alfredo. Dialética da Colonização. São Paulo: Companhia das Letras, 1992. 
. Entre a Literatura e a História. São Paulo: Editora 34, 2013.

. 1970. História Concisa da Literatura Brasileira. São Paulo:

Cultrix,1995.

. Por um historicismo renovado. Reflexo e reflexão em história

literária. Em Literatura e resistência. São Paulo: Companhia das Letras, 2002.

BRANDÃO, Ambrósio Fernandes. Diálogos das Grandezas do Brasil. Recife: Fundação Joaquim Nabuco / Editora Massangana, 1997.

CAMARGO, Iberê. A Gaveta dos Guardados. São Paulo: Cosac Naif, 2009.

CAMINHA, Pero Vaz de. Carta a El-Rei Dom Manuel sobre o Achamento do Brasil. 1o de maio de 1500. Lisboa: Imprensa Nacional; Casa da Moeda, 1974.

CAMÕES, Luís de. Os Lusíadas. São Paulo: Cultrix, 2009.

CAMPOI, Juliana Flavia de Assis Lourenção. Literatura é literatura, e história é história? As narrativas em nheengatu. In: Estudos sobre o Tupi Antigo e as Línguas Gerais no Brasil. Org. Eduardo de Almeida Navarro e outros. São Paulo: Centro Ángel Rama, 2015.

CAMPOS, Augusto e Haroldo de. Revisão de Souzândrade. Rio de Janeiro: Nova Fronteira, 1986. P. 40.

CANDIDO, Antonio. Iniciação à Literatura Brasileira. Rio de Janeiro: Ouro sobre o Azul, 2004. . Formação da Literatura Brasileira. $1^{\circ}$ volume. São Paulo: Livraria Martins Editora, 1959.

. Literatura e Sociedade. Rio de Janeiro: Ouro sobre o Azul, 2006.

. Tese e Antítese. Rio de Janeiro: Ouro sobre o Azul, 2012. 
CANETTI, Elias. A Língua Absolvida: história de uma juventude. São Paulo: Companhia das Letras, 1987.

CARDOSO DE OLIVEIRA, Roberto. Caminhos da Identidade: ensaios sobre etnicidade e multiculturalismo. Brasília: Paralelo 15, 2006.

CARNEIRO, Henrique Soares. Occupy movimentos de protestos que tomaram as ruas. São Paulo: Carta Maior / Boitempo Editorial, 2012.

CARNEIRO, Maria Luíza Tucci. O anti-semitismo nas Américas: memória e história. São Paulo: Edusp, 2007.

CARPEAUX, Otto Maria. Introdução. In: História da Literatura Ocidental. Rio de Janeiro: Alhambra, 1978.

Ensaios reunidos (1942-1978). Vol. 1 e 2. Rio de Janeiro: Univer Cidade-Topbooks, 2005.

CARVALHO, Ronald de. Pequena História da Literatura Brasileira. Rio de Janeiro: F. Briguiet \& C. Editores, 1937.

CASCUDO, Luís da Câmara. Câmara Cascudo e Mário de Andrade. Cartas, 1924 - 1944. Organização e notas de Marcos Antonio Moraes. São Paulo: Editora Global, 2010.

.História da Literatura Brasileira. Literatura

Oral. Rio de Janeiro: Livraria José Olympio Editora, 1952.

CASTELlO, José Aderaldo. A Literatura Brasileira. Origens e Unidade. Vol. 1. São Paulo: EDUSP, 1999.

CASTRO, Eduardo B. Viveiros de. 2002. A Inconstância da Alma Selvagem. São Paulo: Cosac Naify, 2002.

CASTRO, Josué de. A Cidade do Recife. Rio de Janeiro: Livraria da Casa do Estudante do Brasil, 1954. 
CAVALCANTI, Vanildo Bezerra. "Olinda e sua Formação Literária." Revista do Arquivo Público. Recife: 31-32 [33-34]:3-152, 1977-1978).

CESAR, Ana Cristina. Literatura não é documento. In: Crítica e Tradução. São Paulo: Editora Ática, 1999.

CHAMlian, Helena C. Relatório de Pesquisa: A Formação do Professor Universitário na USP. São Paulo: abril de 1996.

. Relatório de Pesquisa: Docentes da Universidade

Vida, Perfil e Formação. São Paulo: abril de 1998. - Professores Inovadores da USP e questão da formação do docente universitário. Cadernos de Pesquisa, n. 118, p.41-64, março/2003; - Experiências de Pesquisa: o sentido da

Universidade na formação docente. Tese de Livre Docência. São Paulo: FEUSP, 2004.

CHARTIER, Roger. Cultura Escrita, Literatura e História. Porto Alegre: Artmed Editora, 2001.

COMPAGNON, Antoine. Literatura para quê?? Belo Horizonte: Editora UFMG, 2009.

CORREA, Dora Shellard. Historiadores e Cronistas e a Paisagem da Colônia Brasil. In: Natureza e Cultura. Revista Brasileira de História. São Paulo: ANPUH, 2006.

COUTINHO, Afrânio. A Literatura no Brasil. Rio de Janeiro: Editorial Sul Americana S. A., 1968.

CURY, Carlos Roberto Jamil. Laicidade na República Federativa do Brasil. http://www.scielo.br/pdf/rbedu/n27/n27a12.pdf. Acesso em 18 de setembro de 2015.

DANIEL, João Pe. Tesouro Descoberto no Máximo Rio Amazonas. Belém: Contraponto Editora, 2004. Vol.1. 
DANTAS, George Alexandre Ferreira. Leituras Viajantes. In: A cidade colonial entre olhares estrangeiros. A Formação das Representações sobre a cidade colonial no Brasil. São Carlos: EESC - USP, Tese de Doutorado, 2009.

DARNTON, Robert. História da Leitura. In: A Escrita da História. Novas Perspectivas. Peter Burke (org.) São Paulo, UNESP, 1992.

DELISLE, Jean / WOODSWORTH, Judith. Os tradutores na história. São Paulo: Ática, 2003.

DOMINICÉ, Pierre. L' histoire de vie comme processus de formation. Paris: Édition L'Harmattan, 1992.

Durkheim, Émile. Poder da Educação. Meios de Ação. In: Educação e Sociologia. São Paulo: Editora Hedra, 2010.

ECO, Umberto. Intentio Lectoris. Apontamentos sobre a Semiótica da Recepção. In: Os Limites da Interpretação. São Paulo: Editora Perspectiva, 2015. Como se Faz uma Tese. São Paulo: Ed. Perspectiva, 1986. Quase a mesma coisa. Rio de Janeiro: Record, 2007.

ELIADE, Mircea. A Estrutura dos mitos: tentativa de definição do mito. In: Mito e Realidade. São Paulo: Editora Perspectiva, 1972.

FARIAS, Sônia Lúcia Ramalho de e LEITE, João Denys Araújo (Org.) Imagens do Brasil na Literatura. Recife: UFPE, 2005.

FELIPE, Cleber Vinicius do Amaral. Mitologia e Emulação Poética em Prosopopeia: Harmonização entre Elementos Potencialmente Conflitantes. Uberlândia: Revista História e Perspectivas, 2009.

FERRONHA, Antônio Luís. O Confronto do Olhar. O Encontro dos Povos na Época das Navegações Portuguesas nos Séculos XV e XVI. Lisboa: Caminho, 1991.

FOUCAULT, Michel. As Palavras e as Coisas. São Paulo: Martins Fontes, 2011. 
- Segurança, Território, População. São Paulo:

Martins Fontes, 2008.

. Vigiar e Punir. São Paulo: Editora Vozes, 1997.

FREYRE, Gilberto. Açúcar. Uma Sociologia do Doce, com Receitas de Bolos e Doces do Nordeste do Brasil. São Paulo: Global, 2012.

Interpretação do Brasil. São Paulo, Global, 2015.

Guia Prático, Histórico e sentimental da Cidade

do Recife. Rio de Janeiro, Livraria José Olympio Editora, 1942.

Olinda. $2^{o}$ Guia Prático, Histórico e Sentimental de

Cidade Brasileira. São Paulo: Global, 2007.

Reinventar o Brasil. Gilberto Freyre entre história e

ficção. Porto Alegre: Editora da UFRGS / Editora da USP, 2006.

FURTADO, Celso. A Economia da Cana de Açúcar. In: Economia colonial no Brasil nos séculos XVI e XVII. São Paulo: HUCITEC, 2001.

GALEANO, Eduardo. Bocas del Tiempo. Buenos Aires: Siglo Veintiuno Editores S. A, 2010.

GANDAVO, Pero de Magalhães. Tratado da Terra do Brasil. História da Província Santa Cruz. Belo Horizonte: Editora Itatiaia / EDUSP, 1980.

GARDNER, Harvey. Apresentação. In: Travels in Brazil. Southern Illinois University Press, 1966, EUA.https://www.questia.com/read/14759866/travels-in-brazil. Acesso em 02 de maio de 2016.

GOMES, Renato Cordeiro. Cartografias Urbanas: Representações da Cidade na Literatura Urbana. Revista da Cátedra Padre Antonio Vieira de Estudos Portugueses, Rio de Janeiro, n.1. 2002. http://www.let.pucrio.br/unidades\&nucleos/catedra/ Acesso em 10 de junho de 2015. 
GOSWAMI, Manu. Producing India. From Colonial Economy to National Space. Chicago \& London: University of Chicago Press, 2004.

HANSEN, João Adolfo. Cartas do Brasil. 1626-1697. Estado do Brasil e Estado do Maranhão e Grão Pará. São Paulo: Hedra, 2003. Letras Coloniais e Historiografia Literária. Rio de Janeiro: UERJ, 2015. Sobre as letras coloniais, a historiografia e a crítica literárias. Campo Grande: Editora UFMS, 2009.

HARTOG, François. Régimes d'Historicité. Présentisme et Expériences du Temps. Paris: Èditions Du Seuil, 2003.

HAUSER, Arnold. História Social da Arte e da Literatura. São Paulo: Martins Fontes, 1995.

HOLANDA, Sérgio Buarque de. Antologia dos Poetas Brasileiros da Fase Colonial. São Paulo: Editora Perspectiva, 1979.

\section{História Geral da Civilização}

Brasileira. São Paulo: Difel, 1986.

. Capítulos de Literatura Colonial. São

Paulo: Brasiliense, 1991.

. Visão do Paraíso. Os motivos edênicos no descobrimento e colonização do Brasil. São Paulo: Brasiliense, 2002.

HOMEM, António Pedro Barbas. História das Relações Internacionais. O Direito e as Concepções Políticas na Idade Moderna. Coimbra: Almedina, 2010.

HOMERO. Odisseia. Tradução de Trajano Vieira. São Paulo: Editora 34. 2.ed. 2011-2012. 
IANNI, Octavio. Enigmas da Modernidade-Mundo. Rio de Janeiro: Civilização Brasileira, 2000.

. Imperialismo e Cultura. Petrópolis: Vozes, 1976.

A ideia do Brasil moderno. São Paulo: Brasiliense, 1994.

JAUSS, Hans Robert. A Literatura e o Leitor: textos de estética da recepção. São Paulo: Paz e Terra, 2001.

KANTOR, Iris. As Academias Brasílicas e a Transmissão do Conhecimento no Brasil Colônia. In: Revista Da Biblioteca Mário de Andrade. São Paulo: Imprensa Oficial, 2007. Dossiê Impressão Régia, V.63.

KARNAL, Leandro e FREITAS NETO, José Alves (org.). A Escrita da Memória. São Paulo: Instituto Cultural Banco Santos, 2004.

KOSTER, Henry. Como melhorar a escravidão. Natal: EDUFRN, 2003. . Viagens ao Nordeste do Brasil. São Paulo: Companhia Editora Nacional, 1942.

Travels in Brazil. Carbondale: Southern Illinois University Press, 1966.

KOTHE, Flávio R. O Cânone Colonial. Brasília: UNB, 1997.

LARANJEIRA, Mário-Poética da Tradução. Do sentido à significância. São Paulo: EDUSP/FAPESP, 1993.

LE GOFF, Jacques. Passado / Presente. In: História e Memória. Campinas: UNICAMP, 2006.

LEITE, Ilka Boaventura. Antropologia da viagem. Escravos e libertos em Minas Gerais no século XIX. Belo Horizonte: UFMG, 1996.

LESTRINGANT, Frank. O Modelo Cosmográfico. In: A Oficina do Cosmógrafo. São Paulo: Civilização Brasileira, 2009. 
LEVI-STRAUSS, Claude. Tristes trópicos. Trad. Gabinete literário Edições 70. Lisboa: Edições 70, 1993.

Antropologia Estrutural Dois. Rio de Janeiro:

Tempo, Brasileiro, 1993.

LÉVY, Pierre. A inteligência coletiva: por uma antropologia do ciberespaço. São Paulo: Loyola, 2010.

LIMA, Ivaldo Marciano de França. Toadas de Maracatu e Músicas de Afoxé: Ressignificação de Valores, Sentidos e Tradições na Cultura Afrodescendente Pernambucana. Feira de Santana: A Cor das Letras, Revista do Departamento de Letras e Artes Universidade Estadual de Feira de Santana, n. 8, 2007.

- Maracatus do Recife: novas considerações sob o olhar dos tempos. Recife: Edições Bagaço, 2012.

LIMA, Luiz Costa. As Formas Híbridas. Um termo elástico ou impreciso? História. Ficção. Literatura. São Paulo: Companhia das Letras, 2011.

A Literatura e o Leitor. Textos de Estética da Recepção.

São Paulo: Paz e Terra, 2002.

LUNA, Jairo Nogueira. De Bento Teixeira a Sousândrade. São Paulo: USP, Dissertação de Mestrado, 1997.

MACHADO, Antonio. XXIX. Proverbios y Cantares. In: Poesías Completas. Madrid: Espasa, 2010.

MÄDER, Maria Elisa Noronha de Sá. O Vazio: o Sertão no Imaginário da Colônia nos Séculos XVI e XVII. Rio de Janeiro: Dissertação de Mestrado, Departamento de História, Pontifícia Universidade Católica, 1995.

MAISTRE, Xavier. Viagem ao Redor do Meu Quarto. Porto Alegre: Mercado Aberto, 1998. 
MARQUES, Mário Reis. História do Direito Português Medieval e Moderno. Coimbra: Almedina, 2009.

MARTINON, Jean-Pierre. O Mito da Literatura. In: Atualidade do Mito. São Paulo: Livraria Duas Cidades, 1977.

MARTINS, Luciana de Lima. $O$ Rio de Janeiro dos viajantes. $O$ olhar britânico (1800-1850). Rio de Janeiro: Jorge Zahar, 2001.

MEIHY, José Carlos Sebe Bom. “A Colônia Brasilianista: História oral de vida acadêmica”. São Paulo: Nova Stella, 1990.

MELO NETO, João Cabral de. A escola das facas. Auto do Frade. Rio de Janeiro: Alfaguara, 2008. Melhores Poemas de João Cabral de Melo Neto. Org. de Antonio Carlos Secchin. São Paulo: Global Editora, 2004. . Um poema sempre se fazendo. Cenas da vida de Joaquim Cardozo. In: Poemas Pernambucanos. Rio de Janeiro: Nova Fronteira, 1999.

Obra Completa. Rio de Janeiro: Nova Aguilar, 2006.

MELO, José Antonio Gonçalves de. Estudos Pernambucanos: crítica e problemas de algumas fontes da história de Pernambuco. Recife: Fundação do Patrimônio Histórico e Artístico de Pernambuco - FUNDARPE, 1986.

MENDONÇA, Heitor Furtado de. Primeira Visitação do Santo Ofício às partes do Brasil. Denunciações de Pernambuco. Coleção para melhor se conhecer o Brasil. Homenagem de Paulo Prado. São Paulo: 1929.

MERQUIOR, José Guilherme. De Anchieta a Euclides. Breve História da Literatura Brasileira - I. Rio de Janeiro: Livraria José Olympio Editora, 1977.

MICELI, Paulo. O Ponto Onde Estamos. Campinas: Editora da UNICAMP, 2008. 
MICHELETTI, Guaraciaba (coord.) Leitura e Construção do Real. O lugar da poesia e da ficção. São Paulo: Cortez Editora, 1999.

MIGNOLO, Walter D. "Dominios Borrosos y Dominios Teóricos: Ensayo de Elucidación Conceitual”. Buenos Aires, Facultad de Filosofia y Letras, ano xx, 1985, PP.21-40.

MILTON, John. Tradução: Teoria e Prática. São Paulo: Martins Fontes Editora, 1998.

MOISÉS, Massaud. A Criação Literária. Poesia. São Paulo: Cultrix, 1997. . A Análise Literária. São Paulo: Cultrix, 2012. A Literatura Brasileira Através dos Textos. São Paulo: Cultrix, 2010. . A Literatura Portuguesa Através dos Textos. São Paulo: Cultrix, 2010. . Dicionário de Termos Literários. São Paulo: Cultrix, 2004.

- História da Literatura Brasileira. Modernismo. São Paulo: Cultrix, 1995.

MOLINA, Géraldine. La question de la valeur et de l'utilisation sociales de la littérature: la littérature un embrayeur du 'vivre-ensemble', 'du faire société en ville? In: Les faiseurs de ville et la littérature: lumières sur star-system contemporain et sés discours publics. Des usages de la littérature au service de l'action des grands architectes-urbanistes. Tome 1. Toulouse: L’Université de Toulouse II - Le Mirail, 2010.

MONTAIGNE, Michel de. Ensaios. São Paulo: Abril Cultural, 1972.

MORSE, Richard M. Novo Mundo: Dois Mundos. O Espelho de Próspero. Cultura e Ideias nas Américas. São Paulo: Companhia das Letras, 1988. 
MUHANA, Adma Fadul. A Prosopopeia de Bento Teixeira: epopeia de derrotas. Campinas: Komedi, 2005.

A Epopeia em Prosa Seiscentista: uma definição de Gênero. São Paulo: FFLCH - USP, Tese de Doutoramento, 1996.

NABUCO, Joaquim. O Direito no Brasil. São Paulo: Nacional, 1941. Minha formação. São Paulo: Editora 34, 2012.

NOGUEIRA, Érico. A Lírica Laudatória no Livro Quarto das Odes de Horácio. São Paulo: USP, Dissertação de Mestrado, 2006.

NORONHA, Ibsen José Casas. Aspectos do Direito no Brasil Quinhentista. São Paulo: Almedina, 2008.

NÓVOA, António. Para o estudo sócio-histórico da gênese $e$ desenvolvimento da profissão docente. In: Teoria e Educação 04, 1991.

(Org.). Vida de professores. Porto: Porto Ed., 1992.

O’GORMAN, Edmundo. O Processo de Invenção da América. A invenção da América. São Paulo: Editora UNESP, 1992.

OLIVEIRA, Leonidas Henrique de. Ciranda Pernambucana uma dança e uma música Popular. Recife: Monografia apresentada ao curso de Especialização em cultura Pernambucana, 2007.

PÁDUA, E.M. M. Metodologia de Pesquisa. Campinas: Papirus Editora, 2000.

PAZ, Octavio. El Laberinto de la Soledad. Madrid: Cátedra, 2007.

PÉCORA, Alcir. Arquivos do Presente. São Paulo: Revista CULT, nº 168, maio de 2012. 
In: Máquina de Gênero - novamente descoberta e aplicada

a Castiglione, Della Casa, Nóbrega, Camões, São Paulo: EDUSP, 2001.

PEIXOTO, Afranio (Prefácio). Bento, Teixeira. Prosopopea. Publicações da Academia Brasileira. Clássicos Brasileiros. I - Literatura. Rio de Janeiro: Álvaro Pinto, Editor, 1923.

PEREIRA, Kênia Maria de Almeida. A Poética da Resistência em Bento Teixeira e Antonio José da Silva, o Judeu. São Paulo: Editora Anna Blume, 1998.

.O Poeta e o Professor Bento

Teixeira: Transgressão e Censura no Brasil do Século XVI. Uberlândia: Centro Universitário do Triângulo.

POLO, Marco. Aqui começa a introdução do livro denominado: A Descrição do Mundo. Livro Primeiro. In: O Livro das Maravilhas. Porto Alegre: L\&PM, 2015.

POLO, Marco. El libro de Marco Polo anotado por Cristóbal Colon. El libro de Marco Polo de Rodrigo de Santaella. Madrid: Alianza Universidad, 1987.

POMPA, Cristina. Religião como tradução. Missionários, Tupis e Tapuias no Brasil Colonial. Florianópolis: EDUSC, 2003.

POUND, Ezra. ABC of Reading. London:.Faber and Faber, 1991. .A Arte da Poesia. São Paulo: Cultrix, 1988.

RABELLO, Felipe Simas; TELES, Gilberto Mendonça. UT pictura poesis: um panorama histórico das relações entre poesia e pintura. Rio de Janeiro: 2014. Tese de doutorado - Departamento de Letras - Pontifícia Universidade Católica do Rio de Janeiro.

RÊGO, José Lins do. "Prefácio". In: Freyre, Gilberto. Região e Tradição. Rio de Janeiro: Gráfica Record Editora, 1968. 
REZENDE, Neide Luzia de (org.). Linguagem e Educação. Implicações Técnicas, Éticas e Estéticas. São Paulo: Humanistas, 2006.

RIBEIRO, Eneida Beraldi. Bento Teixeira e a "Escola de Satanás". O Poeta que teve a prisão por recreação, a solidão por companhia e a tristeza por prazer. Orientador: Anita Waingort Novinsky. São Paulo: USP, Tese de Doutorado, 2006.

Bento Teixeira: Inquisição e Sociedade Colonial. Porto Alegre: Revista do Instituto Cultural Judaico Marc Chagall. V.4 n.1 (jan-jun) 2012.

RIBEIRO, Darcy. O Povo Brasileiro. São Paulo: Companhia de Bolso, 2013.

RINALDI, Lucinéa. Cronistas de viagem e viajantes cronistas: o pêndulo da representação no Brasil Colonial. São Paulo: USP, Dissertação de Mestrado em Literatura Brasileira no DLCV / FFLCH, 2007.

. Cultura e Direito Ambiental: a Tutela Constitucional Protetiva. São Paulo, UNIFMU, 2014.

RONCARI, Luiz. Literatura Brasileira. Dos Primeiros Cronistas aos Últimos Românticos. São Paulo: EDUSP, 2002.

ROSENFELD, Anatol. O Teatro Épico. São Paulo: Editora Perspectiva, 2004.

SÁ, Lúcia. Literaturas da Floresta. Textos Amazônicos e Cultura Latinoamericana. Rio de Janeiro: EDUERJ, 2012.

SAFATLE, Vladimir. O Circuito dos Afetos. Corpos políticos, desamparo e o fim do indivíduo. São Paulo: Cosac Naif, 2016.

SANTOS, Luis Alberto B., PEREIRA, Maria Antonieta. (Org.) Trocas Culturais na América Latina. Belo Horizonte: UFMG, 2000.

SANTOS, Milton. Da totalidade do lugar. São Paulo: Edusp, 2012. 
SANTOS, Boaventura de Sousa. As vozes do Mundo. Rio de Janeiro: Civilização Brasileira, 2009.

Reconhecer para libertar. Os caminhos

do cosmopolitismo multicultural. Rio de Janeiro: Civilização Brasileira, 2003.

SARAIVA, José Antonio. Inquisição e Cristãos-Novos. São Paulo: Nova Limitada, 1969.

SCHMITT, Carl. Le Nomos de La Terre. Paris: Quadrige / PUF, 2001.

SCHWARTZ, Jorge. Vanguarda e Cosmopolitismo. Estudos. São Paulo: Editora Perspectiva, 1983.

SCHWARTZ, Stuart B. O Ofício do Historiador Hoje. Entrevista com Stuart Schwartz. São Paulo: Novos Estudos, 2011.

SEVERINO, A.J. Metodologia do Trabalho Científico. São Paulo: Cortez Editora, 2000.

SILVA, Kalina Vanderlei. O sertão na obra de dois cronistas coloniais: a construção de uma imagem barroca (séculos XVI-XVII). Porto Alegre, Estudos IberoAmericanos. PUCRS, v. XXXII, n. 2, dezembro 2006.

SILVA, Leonardo Dantas. Bento Teixeira e os outros pioneiros das Letras em Pernambuco. Ci. \& Tróp. Recife, v 26, a. 2, p. 303-31 0, juL/dez., 1998.

SILVA, Valéria Torres da Costa e (Org.). Cana Caiana, 1939. Como Polpa de Ingá Maduro: Poesia Reunida de Ascenso Ferreira. Recife: Cepe Editora, 2015.

SIQUEIRA, Sonia Aparecida. O Cristão Novo Bento Teixeira: Cripto Judaísmo no Brasil Colônia. São Paulo: Revista de História, v. XLIV, número 90, 1972.

SOUSA, J. Galante de. Em Tôrno do Poeta Bento Teixeira. São Paulo: Instituto de Estudos Brasileiros, 1972. 
SOUTHEY, Robert. History of Brazil. Vol. 1. London: Hurst, Rees, Ormne and Brown, 1822.

SOUZA, Gabriel Soares. Tratado Descritivo do Brasil em 1587. Belo Horizonte: Editora Itatiaia, 2001.

SOUZA, Laura de Mello \&. O diabo e a Terra de Santa Cruz. São Paulo: Companhia das Letras, 2005.

STRAUSS, Claude - Lévi. Tristes Trópicos. São Paulo: Companhia das Letras, 2001.

TAVARES, Gonçalo M. Uma Viagem à Índia. São Paulo: Leya, 2010.

TEIXEIRA, Anísio. O Estado Democrático e a Educação. Educação é um Direito. Rio de Janeiro, Editora UFRJ, 2009.

TEIXEIRA, Ivan. Multiclássicos Épicos. Prosopopeia. O Uraguai. Caramuru. Vila Rica. A Confederação dos Tamoios. I-Juca-Pirama. São Paulo: Edusp. Imprensa Oficial, 2008.

TEIXEIRA PINTO, Bento. Prosopopeia. Rio de Janeiro: Instituto Nacional do Livro, 1972.

TELES, Gilberto Mendonça. Vanguarda Europeia e modernismo Brasileiro: apresentação e crítica dos principais manifestos vanguardistas. 16.ed. Petrópolis: Editora Vozes, 2000.

TELES, José. Do Frevo ao Manguebeat. São Paulo: Editora 34, 2012.

THEODORO, Janice. A Cultura Ibérica e seu contraponto inglês. Descobrimento da América: A Comemoração como o Narciso da Cultura LatinoAmericana. In América Barroca. São Paulo: Editora Nova Fronteira /Edusp, 1992.

TODOROV, Tzvetan. A Leitura como Construção. In: Os Gêneros do Discurso. São Paulo: Eduções 70, 1978. 
TRABULSE, Elías. Ciencia y tecnología en el Nuevo Mundo. Fideicomiso Historia de las Américas. Serie Ensayos. Ciudad de México: Fondo de Cultura Económica, 1994.

VALENÇA, Alceu. O Poeta da Madrugada. Lisboa: Chiado Editora, 2015.

VARNHAGEN, Francisco Adolfo de. História Geral do Brasil antes de sua separação e independência de Portugal. Revisão e notas de Rodolfo Garcia. $4^{\mathrm{a}}$ ed. São Paulo: 5 vols, 1951.

Cartas sobre a Prosopopeia, de Bento

Teixeira e sobre o Peregrino da América, de Nuno Marques Pereira. Rio de Janeiro: Archivo Nacional, 1929.

VERÍSSIMO, José. História da literatura brasileira [1916]. De Bento Teixeira (1601) a Machado de Assis (1908). Rio de Janeiro: José Olímpio, 1954.

VIANNA, Branca. Questões Linguísticas: Vida, morte e vida da língua geral. In: O Contrário da Memória. São Paulo: Revista Piauí 116, maio de 2-16. P. 52 a 58.

VILAR, Gilberto. O Primeiro Brasileiro. Onde se conta a história de Bento Teixeira, cristão novo, instruído, desbocado e livre, primeiro poeta do Brasil, perseguido pela Inquisição. São Paulo: Marco Zero, 1995.

WISNISK, José Miguel. Veneno remédio: o futebol e o Brasil. São Paulo: Cia das Letras, 2008.

WYLER, Lia. Línguas, poetas e bacharéis. Uma crônica da tradução no Brasil. Rio de Janeiro: Rocco, 2003.

WOORTMANN, Klaas. O selvagem e o Novo Mundo: ameríndios, humanismo e escatologia. Brasília: UNB, 2004. 